\title{
SISTEMA DE AMOSTRAGEM DO SOLO E AVALIAÇÃO DA DISPONIBILIDADE DE FÓSFORO NA FASE DE IMPLANTAÇÃO DO PLANTIO DIRETO
}

MARIA LIGIA DE SOUZA SILVA

Dissertação apresentada à Escola Superior de Agricultura "Luiz de Queiroz", Universidade de São Paulo para obtenção do título de Mestre em Agronomia, Área de Concentração: Solos e Nutrição de Plantas.

PIRACICABA

Estado do São Paulo - Brasil

Dezembro - 2002 


\title{
SISTEMA DE AMOSTRAGEM DO SOLO E AVALIAÇÃO DA DISPONIBILIDADE DE FÓSFORO NA FASE DE IMPLANTAÇÃO DO PLANTIO DIRETO
}

\author{
MARIA LIGIA DE SOUZA SILVA \\ Engenheiro Agrônomo \\ Orientador: Prof. Dr. GODOFREDO CÉSAR VITTI
}

Dissertação apresentada à Escola Superior de Agricultura "Luiz de Queiroz", Universidade de São Paulo para obtenção do título de Mestre em Agronomia, Área de Concentração: Solos e Nutrição de Plantas.

PIRACICABA

Estado do São Paulo - Brasil

Dezembro - 2002 
Dados Internacionais de Catalogação na Publicação (CIP) DIVISÃO DE BIBLIOTECA E DOCUMENTAÇÃO - ESALQ/USP

\author{
Silva, Maria Ligia de Souza \\ Sistema de amostragem do solo e avaliação da disponibilidade de fósforo na \\ fase de implantação do plantio direto / Maria Ligia de Souza Silva. - - Piracicaba, \\ 2002. \\ $97 \mathrm{p}$. \\ Dissertação (mestrado) - - Escola Superior de Agricultura Luiz de Queiroz, \\ 2002. \\ Bibliografia. \\ 1. Análise de planta 2. Fertilidade do solo 3. Fósforo 4. Pedologia 5. Plantio diret \\ 6. Química do solo 7. Soja I. Título
}

CDD 631.42

"Permitida a cópia total ou parcial deste documento, desde que citada a fonte - O autor" 


\section{OFEREÇO}

\section{A DEUS.}

\section{À ESPIRITUALIDADE AMIGA.}

"Preservar a pureza das fontes e a fertilidade do solo.

Campo ajudado, pão garantido." André Luiz (Waldo Vieira).

DEDICO

Aos meus amados pais, Mauro Amaral da Silva e Maria Lourdes de Souza Silva, pelo exemplo de vida e ensinamentos. Aos meus adorados irmãos, Marco, Angélica e Luiza, pela união. Aos meus estimados amigos, pela dedicação. Pois, com amor e compreensão, souberam transmitir-me a força necessária à realização desta tarefa. 


\section{AGRADECIMENTOS}

À DEUS, por ser meu guia e estar sempre presente em minha vida me fortalecendo.

Aos meus pais e irmãos pelo amor, apoio, paciência e compreensão durante a minha vida.

À Escola Superior de Agricultura "Luiz de Queiroz"- Departamento de Solos e Nutrição de Plantas, pela oportunidade concedida para a realização do curso de Mestrado.

Ao Conselho do Programa de Pós-Graduação em Solos e Nutrição de Plantas e a CAPES pela concessão de bolsa de estudo para realização deste curso.

Ao Prof. Dr. Godofredo César Vitti, pela orientação, estimulo, compreensão, paciência e, acima de tudo, pela sua grande amizade.

À Fundação MS - Maracajú/MS, pela disponibilização da área experimental e o apoio oferecido.

Ao Eng. Agr. M. Sc. Dirceu Luiz Broch - Fundação MS, pela amizade e apoio, seu auxílio foi fundamental para o desenvolvimento deste trabalho.

Aos Professores do curso, pelos ensinamentos, colaborações, incentivo e companheirismo. 
Aos meus amigos(as) de curso, pelo apoio, amizade e momentos felizes de descontração.

Aos amigos Gilmar Ribeiro Nachtigall e Jonas Ruchell, pelas sugestões a auxílios dados.

Ao Prof. Dr. Luís Ignácio Prochnow pelas valiosas sugestões.

Aos alunos integrantes do GAPE pela amizade e companheirismo, e todos aqueles que fazem parte da nossa rotina de trabalho, em especial ao Massimiliano César Barros Júnior, pelo grande auxílio dado no início do meu trabalho.

À Silvia, secretária sempre tão prestativa.

Aos funcionários do Departamento de Solos e Nutrição de Plantas, pelo auxílio direto e indireto nos trabalhos.

Aos funcionários dos laboratórios, em especial ao Udso Roberto Moraes, pelo grande auxílio e trabalhos prestados.

Aos funcionários da Biblioteca da ESALQ - USP, pelo ensinamento e apoio à realização das pesquisas.

À secretária da Pós - Graduação em Solos e Nutrição de Plantas, Nancy C. Amaral, pela atenção, amizade e trabalhos prestados.

Aos funcionários da seção de Pós-Graduação, pela atenção e trabalhos prestados.

À todos que direta ou indiretamente contribuíram para elaboração desse trabalho.

À aqueles que sempre se fizeram presente em minha vida. 


\section{SUMÁRIO}

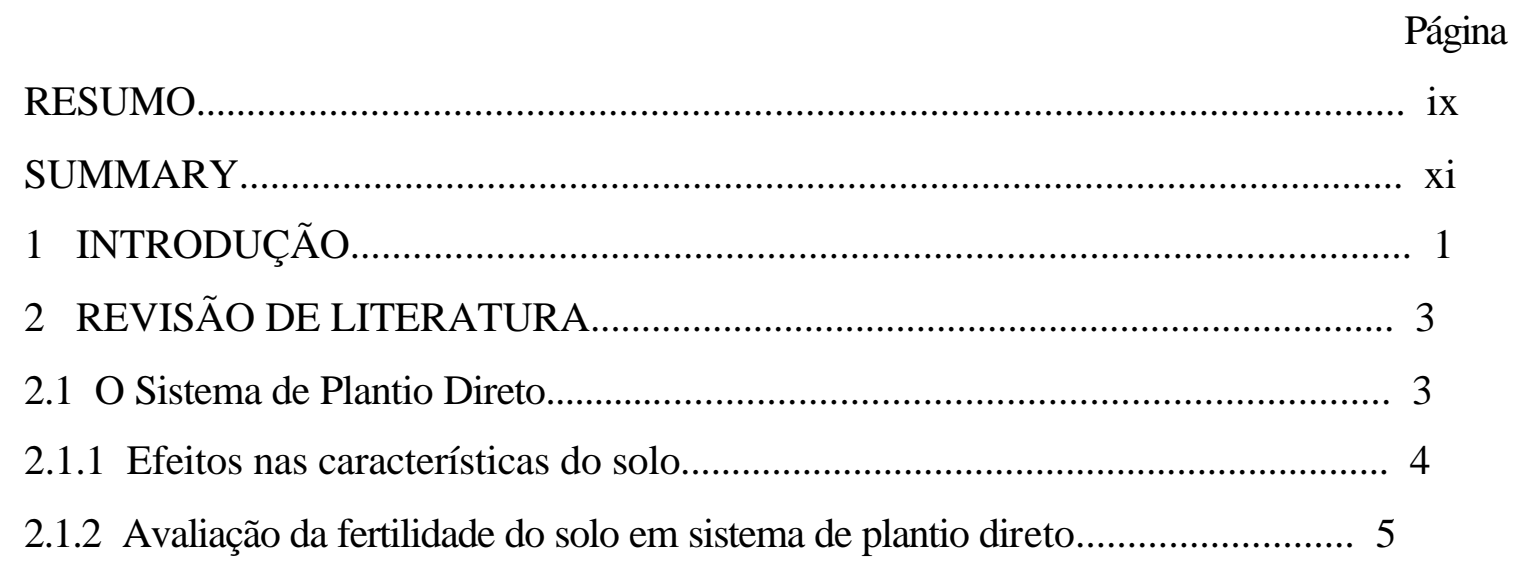

2.1.2.1 Variabilidade horizontal....................................................................... 7

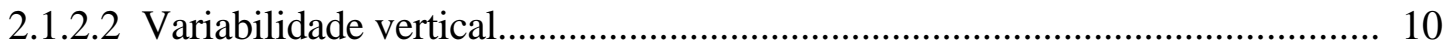

2.1.3 Amostragem do solo em sistema de plantio direto...................................... 11

2.1.3.1 Local de amostragem do solo em sistema de plantio direto........................... 15

2.1.3.2 Profundidade de amostragem do solo em sistema de plantio direto................. 20

2.2 Avaliação da disponibilidade de fósforo em sistema de plantio direto.................. 24

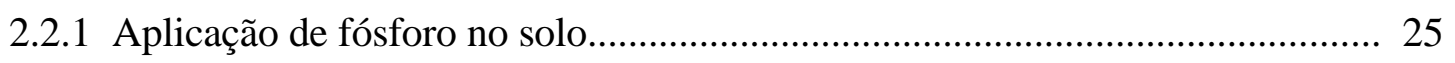

2.2.2 Distribuição de fósforo no solo............................................................... 26

2.2.3 Métodos de avaliação da disponibilidade de fósforo....................................... 28

3 MATERIAL E MÉTODOS............................................................................ 31

3.1 Localização e característica da área experimental.............................................. 31

3.2 Delineamento experimental e tratamentos.................................................... 32

3.3 Instalação do experimento........................................................................ 33

3.3.1 Preparo do solo, adubação e plantio.................................................................. 34

3.4 Obtenção dos resultados............................................................................ 35 
3.4.1 Amostragem de solo e de planta.............................................................. 35

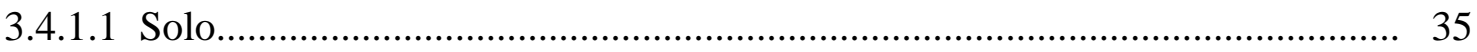

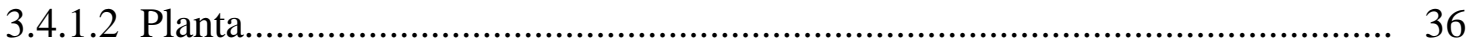

3.4.2 Análises químicas do solo ..................................................................... 36

3.4.2.1 $\mathrm{pH}$ em $\mathrm{CaCl}_{2}$ (acidez ativa) .............................................................. 37

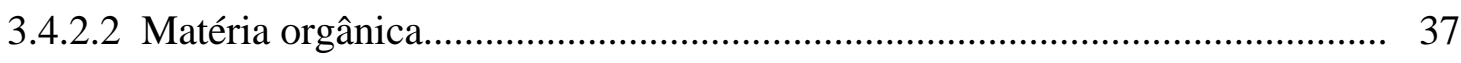

3.4.2.3 Fósforo, potássio, cálcio e magnésio - resina............................................... 37

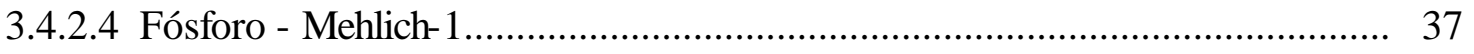

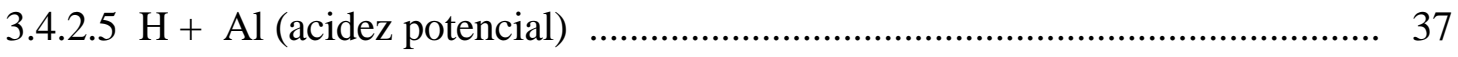

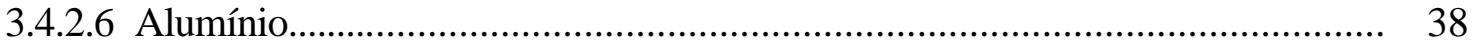

3.4.3 Análise química da planta......................................................................... 38

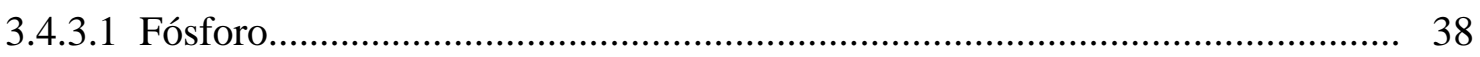

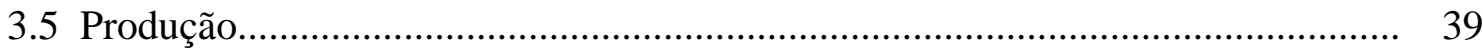

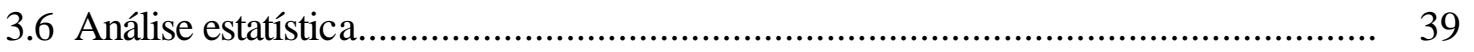

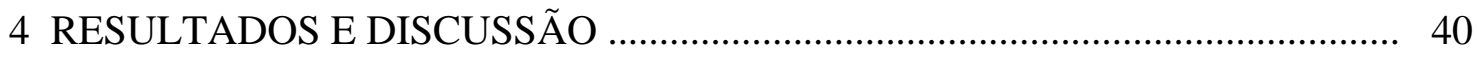

4.1 Avaliação da disponibilidade de fósforo no sistema de plantio direto.................. 40

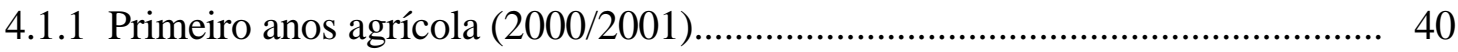

4.1.1.1 Efeito de local e profundidade de amostragem........................................... 40

4.1.1.2 Efeito da fosfatagem e aplicação de fósforo em sulco.................................... 42

4.1.1.3 Correlação entre o fósforo extraído do solo pelo método da resina trocadora de íons e o método Mehlich- 1 ...................................... 49

4.1.1.4 Efeito da fosfatagem e aplicação de fósforo em sulco na produção................ 50

4.1.1.5 Efeito da fosfatagem e aplicação de fósforo em sulco sobre teor de fósforo na planta.............................................................. 53

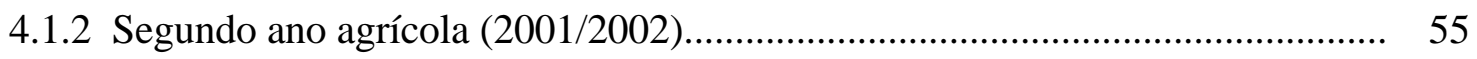

4.1.2.1 Efeito de local e profundidade de amostragem............................................. 55

4.1.2.2 Efeito da fosfatagem e aplicação de fósforo em sulco.................................... 57

4.1.2.3 Correlação entre o fósforo extraído do solo pelo método da resina trocadora de íons e o método Mehlich-1 ......................................63 63

4.1.2.4. Efeito da fosfatagem e aplicação de fósforo em sulco na produção................ 65 
4.1.2.5 Efeito da fosfatagem e aplicação de fósforo em sulco sobre teor de fósforo na planta .......................................................... 67

4.2 Avaliação da fertilidade do solo em sistema de plantio direto............................. 70

4.2.1 Primeiro ano de agrícola (2000/2001) ....................................................... 70

4.2.1.1 Efeito do local e profundidade de amostragem ........................................... 70

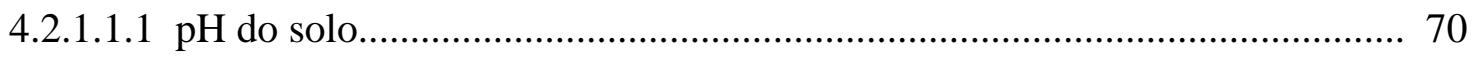

4.2.1.1.2 Matéria orgânica do solo .......................................................................... 71

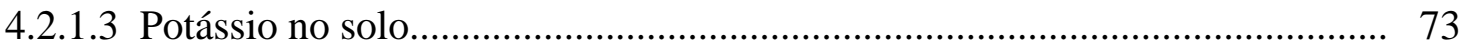

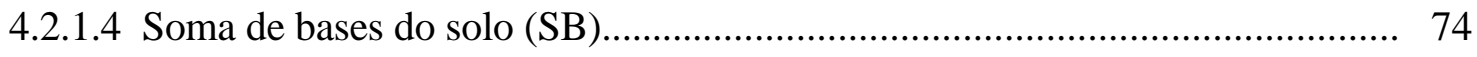

4.2.1.5 Capacidade de troca catiônica do solo (CTC) ….......................................... 75

4.2.1.6 Saturação por bases do solo (V\%)........................................................... 76

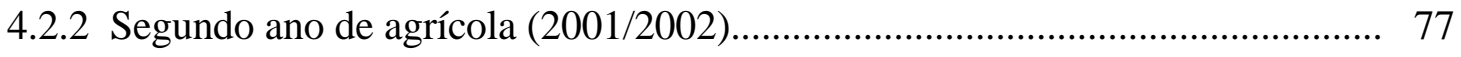

4.2.2.1 Efeito do local e profundidade de amostragem............................................. 77

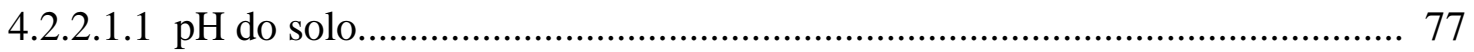

4.2.2.1.2 Matéria orgânica do solo................................................................... 78

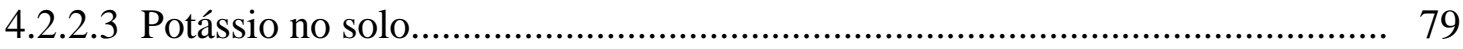

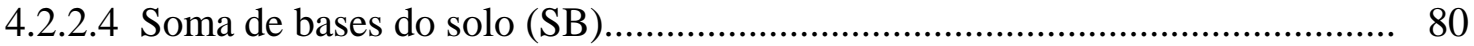

4.2.2.5 Capacidade de troca catiônica do solo (CTC) ............................................. 81

4.2.2.6 Saturação por bases do solo (V\%).......................................................... 82

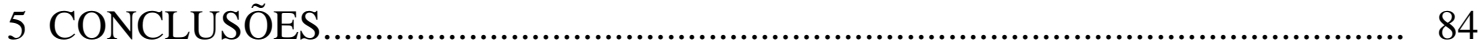

REFERÊNCIAS BIBLIOGRÁFICAS............................................................. 86 


\title{
SISTEMA DE AMOSTRAGEM DO SOLO E AVALIAÇÃO DA DISPONIBILIDADE DE FÓSFORO NA FASE DE IMPLANTAÇÃO DO PLANTIO DIRETO
}

\author{
Autora: MARIA LIGIA DE SOUZA SILVA \\ Orientador: Prof. Dr. GODOFREDO CÉSAR VITTI
}

\section{RESUMO}

Nos últimos anos, o aumento progressivo de áreas cultivadas no sistema plantio direto no Brasil, tem gerado incremento na demanda de informações sobre a variabilidade dos índices de fertilidade do solo utilizados nas recomendações de calagem e adubação. A utilização de adubação fosfatada em linha, pode gerar dois padrões de concentração de fósforo, um na linha e outro na entrelinha, bem como gradiente vertical de fertilidade do solo em sistema de plantio direto, diferenciado do sistema convencional. Deste modo, a amostragem deve ser realizada de modo adequado e representativo à esta situação. O presente trabalho teve por objetivo avaliar diferentes formas de amostragem do solo, em termos de localizações e profundidade e, a disponibilidade de fósforo em função de doses de $\mathrm{P}_{2} \mathrm{O}_{5}$ em área total (fosfatagem) e de $\mathrm{P}_{2} \mathrm{O}_{5}$ aplicados no sulco, em um solo argiloso na fase de implantação do plantio direto. O trabalho foi desenvolvido em área experimental pertencente a Fundação MS, localizada no município de Maracajú - MS, utilizando como cultura a soja, com preparo inicial no sistema convencional e os sucessivos em sistema de plantio direto. $\mathrm{O}$ 
delineamento experimental utilizado foi o de blocos ao acaso com parcelas subdivididas em esquema fatorial 3x5, utilizando-se de três doses para fosfatagem $(0,100$ e $200 \mathrm{~kg}$ $\mathrm{ha}^{-1}$ de $\left.\mathrm{P}_{2} \mathrm{O}_{5}\right)$ e cinco doses de $\mathrm{P}_{2} \mathrm{O}_{5}$ no sulco de plantio $\left(0,45,90,135\right.$ e $180 \mathrm{~kg} \mathrm{ha}^{-1}$ de $\mathrm{P}_{2} \mathrm{O}_{5}$ ), com quatro repetições. Nos anos agrícolas de 2000/2001 e 2001/2002, foram realizados coletas de amostras nas linhas de plantio, nas entrelinhas e tipo mistura (linha e entrelinha na proporção de 1:1), nas profundidades de 0-10, 10-20 e 0-20 cm. No ano agrícola de 2001/2002, foi realizada também amostragem em trincheira (de uma entrelinha à outra, com a linha de plantio centralizada na faixa de coleta). $O$ solo foi analisado quimicamente quanto aos teores de fósforo por dois métodos de extração (resina e Mehlich-1), matéria orgânica, potássio, $\mathrm{pH}$, saturação por bases, CTC e soma de bases. Foram também analisados a produção de soja e os teores de fósforo na planta. Verificou-se que amostragem do solo realizadas nas linhas e amostragem do tipo mistura (linhas e entrelinha) apresentaram maiores teores de fósforo no solo, sendo mais eficientes na quantificação dos teores de fósforo no solo em função da aplicação das doses em fosfatagem e no sulco de plantio. Com a aplicação de $\mathrm{P}_{2} \mathrm{O}_{5}$ em área total e em sulco de plantio, os teores de fósforo no solo, principalmente nas profundidades de 0-10 $\mathrm{cm}$ e $0-20 \mathrm{~cm}$, aumentaram de forma linear. Os teores de fósforo no solo, extraídos pela resina trocadora de íons, em amostras coletadas nas linhas de plantio e as tipo mistura, nas profundidades 0-10 e 0-20 cm, apresentaram melhor correlação (positiva e significativa) com os teores de fósforo na planta, obtidos pela técnica da diagnose foliar, e com a produção de grãos de soja, em relação ao método de extração Mehlich-1. 


\title{
SOIL SAMPLING SYSTEM AND EVALUATION OF THE AVAILABILITY OF PHOSPHORUS IN THE PHASE OF IMPLANTATION OF THE NO TILLAGE SYSTEM
}

\author{
Author: MARIA LIGIA DE SOUZA SILVA \\ Adviser: Prof. Dr. GODOFREDO CÉSAR VITTI
}

\section{SUMMARY}

In the latest years the increase in areas cultivated under the no-tillage system in Brazil has generated an increment in the demand for information related to the variability in the soil fertility attributes used as parameters for recommendations of fertilizers and lime. The localized phosphate fertilization, can create two standards of phosphorus concentration, one in the line and another in the space between lines, as well as a vertical gradient of soil fertility, used in the no tillage system, which differs from the tillage system. The soil sampling must be carried out in a representative way to really predict the soil fertility under the no tillage system. The present work had the objective to evaluate different forms of soil sampling, in terms of localization and depth, to correctly predict the phosphorus availability as a function of phosphorus levels applied broadcast and in row, in the implantation of the no-tillage system. The work was developed at the experimental station of Fundação MS, located in the city of Maracajú/MS, using soybean as the testing crop, with initial preparation in the tillage system followed by the no-tillage system. The experimental design was of a split-plot in a factorial $3 \times 5$, using three levels of phosphorus applied broadcast $(0,100$ and $200 \mathrm{~kg}$ 
$\mathrm{ha}^{-1}$ of $\left.\mathrm{P}_{2} \mathrm{O}_{5}\right)$ and 5 levels of phosphorus applied in the row $(0,45,90,135$ and $180 \mathrm{~kg}$ $\mathrm{ha}^{-1}$ of $\mathrm{P}_{2} \mathrm{O}_{5}$ ), with four repetitions. In the agricultural years of 2000/2001 and 2001/2002, samples were collected in row, inter row and the mixture of the two (row and inter row in the ratio of 1:1), in the depths of $0-10,10-20$ and $0-20 \mathrm{~cm}$. In the agricultural year of 2001/2002, samples were also collected from the middle of one row to the other. The phosphorus by two extraction methods, resin and Mehlich-1, organic matter, potassium, pH, base saturation, ECC (exchange cationic capacity) and base sum, were determined in the soil samples. Also the soybean yield and the phosphorus concentration in the plant were determined. It was verified that sampling the soil in the row and by mixing presented higher contents of phosphorus in the soil, being more efficient in the quantification of the content of phosphorus in the soil as a function of the application rates applied broadcast and in row. With the application of phosphorus levels broadcast and in row, the content of phosphorus in the soil, mainly in the depths of 0-10 and $0-20 \mathrm{~cm}$, increased in a linear form. The relations between the phosphorus concentration in the soil with phosphorus concentration in the plant or yield of soybean were better with the resin extractor, as compared to the Mehlich 1, and when soil samples were collected from $0-10$ and $0-20 \mathrm{~cm}$ in the row or by mixing samples from the row and inter row. 


\section{INTRODUÇÃO}

O solo, um recurso natural muito importante na produção de alimentos, deve ser considerado não somente como base de sustentação econômica da produção agrícola, mas também na preservação do meio ambiente.

Um modelo de agricultura, que buscava grandes aumentos na produção agrícola, baseado na adoção da mecanização agrícola e na utilização de grandes quantidades de insumos industrializados, associado ao sistema convencional de cultivo, quando mal conduzido causou, ao longo do tempo, intensa degradação do solo, que resultou na necessidade de introduzir e desenvolver técnicas mais conservacionistas de uso do solo.

O plantio direto é um processo de semeadura em solo não revolvido e devidamente protegido por resíduos vegetais de culturas anteriores, no qual as sementes são colocadas em sulcos ou covas, com largura e profundidade suficiente para adequada cobertura das mesmas com o solo.

Esse sistema vem se consolidando como uma das estratégias mais eficazes para melhorar a sustentabilidade da agricultura em regiões tropicais e subtropicais. Sua adoção em substituição à pratica convencional deve ser considerada como um investimento na gestão dos recursos naturais e sócio-econômicos, cujos principais impactos são assegurados pela conservação do solo e economia no uso de maquinários e produtos agroquímicos.

Como qualquer sistema de produção, a probabilidade de êxito ou fracasso na implementação do plantio direto está condicionada a uma série de requisitos de natureza estrutural, gerencial e tecnológica. Dentre tais requisitos, destaca-se o manejo da fertilidade do solo como um componente fundamental para uma agrícola sustentável. 
Um dos princípios básicos desse sistema é a manutenção da palhada na superfície do solo e o seu não revolvimento, fazendo com que os fertilizantes aplicados se concentrem juntamente com a palhada, na parte superior do perfil do solo, fazendo com que ocorra um gradiente de concentração de atributos de fertilidade do solo.

Do ponto de vista da fertilidade do solo, diversos trabalhos enfocam o efeito da mineralização dos resíduos culturais no acumulo de nutrientes na camada superficial do solo influenciando as culturas em rotação. Entre os macronutrientes, o fósforo, em vista da sua baixa mobilidade no solo e a suscetibilidade às reações de fixação, vem ocupando a atenção em inúmeros trabalhos relacionados ao modo de aplicação.

A variabilidade do solo, principalmente nos seus atributos químicos, num sistema de plantio direto é maior do que no preparo convencional, tanto no sentido horizontal, como em profundidade no perfil do solo.

Os procedimentos de coleta de amostras de solo para fins de recomendação de calagem e adubação, elaboradas regionalmente no Brasil, consideram o tipo e magnitude da variabilidade que caracteriza o preparo convencional do solo. Como os índices de fertilidade são alterados, entre um sistema e outro, dificilmente este procedimento resultará numa coleta de amostras representativas do estado de fertilidade do solo em sistema de plantio direto. Deste modo, o sistema de plantio direto cria um ambiente no solo diferente daquele verificado no sistema convencional, principalmente, no tocante ao acúmulo superficial de matéria orgânica e de fertilizantes, representando novos desafios para a amostragem do solo.

O presente trabalho teve por objetivo avaliar diferentes formas de amostragem do solo, em termos de profundidade $(0-10 \mathrm{~cm}, 10-20 \mathrm{~cm}$ e $0-20 \mathrm{~cm})$ e localizações (linha, entrelinha e mistura de ambas), e a disponibilidade de fósforo em um solo na fase de implantação do plantio direto, através da aplicação de doses de fósforo em área total (fosfatagem) e de fósforo aplicados no sulco, na cultura da soja, por dois anos agrícolas consecutivos. 


\section{REVISÃO DE LITERATURA}

\subsection{O sistema de plantio direto}

Em regiões tropicais, onde a fertilidade natural do solo é limitada, devido ao intenso processo pedogenético, a elevada acidez, associada à pobreza de bases trocáveis, com teores de alumínio expressivos e a carência em fósforo, tem sido a principal causa da limitação da produção de alimentos destes solos (Kampratt, 1977).

Para Sá (1995), a adoção de métodos de preparo, tem por objetivo principal a melhoria das propriedades químicas, visando aumentar o seu potencial produtivo. $\mathrm{O}$ intenso revolvimento do solo para implantação das culturas, coincidindo em geral, com a ocorrência de elevadas precipitações durante os estádios de desenvolvimento, tem provocado ao longo dos anos, expressivas perdas de solo por erosão (Wunche et al., 1978), que segundo estimativas de Cogo (1991), estão na ordem de 30 ton. ha ${ }^{-1}$ ano $^{-1}$.

A preocupação em desenvolver estudos sobre sistemas conservacionistas de manejo do solo gerou o entrosamento entre diversos segmentos da industria de máquinas agrícolas, de produtos agroquímicos e de pesquisadores de diversas áreas de atuação (Phillips, 1984). O conceito inicialmente adotado foi derivado da expressão "no-tillage", que significa, sem preparo, definido por Jones et al. (1968), como sendo um procedimento de plantio de uma cultura diretamente sobre uma cobertura morta quimicamente, ou sobre resíduos da cultura anterior, sem o preparo mecânico do leito de semeadura.

Difundido em nosso meio mais como medida de controle à erosão do que como um sistema de cultivo propriamente dito, o plantio direto foi implantado sem que houvesse informações básicas capazes de orientar os componentes envolvidos no 
sistema. Informações sobre o manejo das culturas, controle fitossanitário, manejo de fertilidade do solo, são ainda muito escassas para as nossas condições e necessitam de subsídios para avaliação das modificações que ocorrem no ecossistema solo-planta, os quais poderão ser obtidos somente através de observações a longo prazo. Nessa situação, é necessário que se conheça os efeitos desse sistema de cultivo sobre as propriedades químicas e na disponibilidade de nutrientes na camada arável do solo, para uma adequada orientação sobre quantidades e critérios de fornecimento dos fertilizantes (Muzilli, 1983).

O plantio direto vem crescendo num ritmo acelerado em todo mundo. Com 19,75 milhões de ha, os Estados Unidos é o país onde o plantio direto alcançou a maior difusão em termos de área cultivada, seguindo do Brasil com 13,47 milhões de ha, Argentina com 9,25 milhões de ha, Austrália com 8,64 milhões de ha, Canadá com 4,08 milhões de ha, e Paraguai com 0,8 milhões de ha (Derpsch, 2000).

Estima-se que o plantio direto é utilizado em aproximadamente 58 milhões de ha em todo o mundo. Aproximadamente $83 \%$ da tecnologia está sendo praticada no Continente Americano, cerca de $15 \%$ na Austrália e apenas $2 \%$ na Europa, Ásia e África. Apesar da expansão em termos de área nos Estados Unidos, o plantio direto representa apenas $16 \%$ da área agrícola total do país. No Brasil, a taxa de adoção é de $25 \%$ em relação a área total, enquanto que na Argentina é de $37 \%$ e no Paraguai $52 \%$ (Derpsch, 2000).

\subsubsection{Efeitos nas características do solo}

O sistema de plantio direto produz mudanças nos atributos químicos, físicos e biológicos, exigindo a utilização de novos procedimentos e técnicas de manejo em relação ao sistema convencional (Schlindwein, 1999). Devido a grande deposição de resíduos vegetais (palhada) na superfície do solo, os ácidos orgânicos são produzidos continuamente, participando na ciclagem dos elementos químicos inorgânicos do solo. Há perenização dos ácidos orgânicos derivados dos resíduos depositados na superfície com participação ativa na química dos íons no solo (Pavan, 1997). 
A permanente cobertura do solo aliado a aplicação de fertilizantes e corretivos na superfície do solo ocasiona mudanças nos regimes de umidade e na distribuição de nutrientes no perfil do solo. Souza (1992) relatou que inúmeros trabalhos têm mostrado que o sistema de plantio direto cria no solo, um ambiente diferente daquele encontrado no sistema convencional, resultante do efeito dos resíduos superficiais e da reduzida movimentação do solo. Como conseqüência, tem-se constatado acúmulo de fertilizantes na superfície do solo neste sistema conservacionista.

Já o cultivo convencional promove uma maior aeração e quebra dos agregados do solo, e a incorporação dos resíduos vegetais provoca rápida decomposição e perda do carbono orgânico nativo, assim como uma mineralização do nitrogênio e do fósforo orgânico do solo (Holtz, 1995). Isto faz com que grande proporção dos compostos carbonados atinja rapidamente a fase final do processo de mineralização, havendo assim um impedimento na formação de substâncias mais estáveis no solo, como o húmus (Parra, 1986).

\subsubsection{Avaliação da fertilidade do solo em sistema de plantio direto}

No sistema plantio direto, a aplicação de corretivos e fertilizantes, é realizada na linha, na subsuperfície do solo ou a lanço, na superfície, e a deposição superficial dos resíduos das culturas altera a taxa de decomposição da matéria orgânica e a liberação dos nutrientes na superfície do solo, resultando na formação de gradientes em atributos químicos em profundidade, o qual se intensifica com o tempo de cultivo (Schlindwein \& Anghinoni, 2000b).

Havlin et al. (1990) observaram que o plantio direto proporcionou maior acúmulo de matéria orgânica do que o preparo convencional, principalmente na camada mais superficial do solo (0 a 2,5 cm). Concluíram que, com o passar dos anos, estas diferenças aumentaram também em profundidade.

Carter \& Rennie (1983), estudando os efeitos do plantio direto e convencional nas propriedades químicas do solo sob cultivo há 2, 4, 12 e 16 anos, observaram que, exceto na área há 2 anos sob plantio direto, o carbono e o nitrogênio da biomassa 
microbiana e o potencial de mineralização do nitrogênio e do carbono foram significativamente maiores na superfície do solo. A maiores profundidades, no entanto, ocorreu uma reversão da situação, quando no preparo convencional o carbono e o nitrogênio da biomassa se distribuíram igualmente em profundidade, e no plantio direto se concentraram na superfície, devido à presença da palhada.

Bayer \& Mielniczuk (1997) verificaram que os teores de carbono total e a capacidade de troca de cátions (CTC) aumentaram na camada superficial do solo após cinco anos de plantio direto. Sidiras \& Pavan (1985), observaram que no plantio direto, a partir de três a quatro anos, os valores de $\mathrm{pH}$, de $\mathrm{Ca}+\mathrm{Mg}$ trocáveis, $\mathrm{K}$ trocável e $\mathrm{P}$ extraível do solo aumentaram na camada superficial $(0-10 \mathrm{~cm})$ do solo.

No sistema de plantio direto, a distribuição e acumulação de potássio, cálcio e magnésio trocáveis mostram-se de ocorrência superficial, com redução gradativa da sua disponibilidade nas camadas mais profundas. Assim, nas pesquisas realizadas sobre o comportamento destes elementos, em sistema de semeadura direta, os resultados encontrados são semelhantes quanto à sua distribuição no perfil solo (Muzilli, 1983).

O potássio, diferente do fósforo, dilui-se parcialmente na água e é transportado para camadas mais profundas. A maior quantidade encontra-se na camada superficial, até $5 \mathrm{~cm}$ de profundidade, e as variações maiores ocorrem na camada de 5 a $15 \mathrm{~cm}$. É importante salientar a variação nos teores de fósforo e potássio no solo, no sentido perpendicular à linha de semeadura, cujos teores variaram cerca de 15 a $32 \mathrm{mg}$ $\mathrm{dm}^{-3}$ para fósforo, e 3 a $7 \mathrm{mmol}_{\mathrm{c}} \mathrm{dm}^{-3}$ para potássio (Sidiras \& Pavan, 1985).

Muzilli (1983) verificou decréscimo nos teores de potássio, cálcio e magnésio com a profundidade da camada arável. Similarmente, Eltz et al. (1989), trabalhando em um Latossolo Bruno álico, em plantio direto, verificaram uma maior concentração de potássio trocável, cálcio e magnésio na superfície, ou seja, até $8 \mathrm{~cm}$ de profundidade. Isto pode significar maior disponibilidade para a cultura, desde que exista água para o fluxo do elemento.

Baseado em dados sobre absorção de potássio pelas plantas e considerando a mobilidade e a solubilidade no solo, alguns especialistas sugerem a possibilidade de aplicar o potássio em cobertura à semelhança do nitrogênio. Os resultados de 
experimentos evidenciam que o potássio no sulco de semeadura resulta em colheitas equivalentes às obtidas com aplicações parceladas no plantio e em cobertura. Havendo dificuldade na obtenção de fórmulas que atendam a necessidade de fertilização, pode-se buscar a melhor alternativa possível na semeadura, complementando a quantidade necessária misturando com fontes de $\mathrm{N}$ na adubação de cobertura, na superfície do solo Eltz et al. (1989).

O desequilíbrio nutricional provocado pela aplicação de grandes quantidades de fertilizantes na linha de semeadura sob plantio direto pode provocar sintomas de deficiência de alguns elementos no início do desenvolvimento das plantas. O molibdênio pode ser liberado com a aplicação de calcário. O excesso de fósforo e calcário mal distribuído podem induzir a deficiência de zinco. Com o crescimento das raízes, o desequilíbrio torna-se menos evidente e os sintomas tornam-se caracterizados como deficiência de micronutrientes desaparecem (Gassen \& Gassen, 1996).

Sabe-se que a ação antrópica na prática da agricultura, no sistema convencional, altera as características químicas do solo, pela utilização de corretivos, fertilizantes, causando maior variabilidade do solo (Couto, 1997), que é aumentada no sistema plantio direto pela ação residual dos fertilizantes nas adubações em linha (Kray et al., 1998) e em superfície juntamente com os resíduos culturais reciclados (Anghinoni $\&$ Salet, 1998).

A heterogeneidade é uma condição intrínseca do solo. Ela ocorre naturalmente, tanto no sentido horizontal como vertical, resultando do efeito conjugado dos fatores de exploração do solo. No caso de uma paisagem cultivada, fontes adicionais como o manejo exercido pelo homem contribuem para o aumento da heterogeneidade natural do solo (Anghinoni \& Salet, 1998).

\subsubsection{Variabilidade horizontal}

A rotação de culturas é uma condição básica para o sucesso e continuidade do

sistema plantio direto. Entretanto, numa mesma área, culturas com diferentes espaçamentos são cultivadas, e as linhas de adubação, geralmente, não coincidem. 
Porém, após alguns anos, quando o sistema plantio direto já estiver estabelecido (com mais de cinco anos), é de se esperar que haverá uma variabilidade horizontal menor do que na fase de implantação do mesmo (Anghinoni \& Salet, 1998).

Quando as colheitadeiras fazem uma perfeita distribuição da palhada na superfície do solo e as adubações no sistema plantio direto são à lanço, espera-se uma variabilidade horizontal semelhante à do sistema convencional. Porém, quando as adubações são feitas na linha de semeadura ocorre uma maior concentração de alguns nutrientes na linha, principalmente os menos móveis, causando maior variabilidade (Kray et al., 1998).

Os resultados de estudos (Souza et al., 1998; Anghinoni \& Salet, 1998) em lavouras consolidadas (mais de cinco anos) no sistema plantio direto no Sul do Brasil, confirmam a maior variabilidade dos índices de fertilidade do solo nesse sistema em relação ao preparo convencional, especialmente para o fósforo disponível com adubação em sulcos, que inclusive apresentou correlação ou dependência espacial. Souza et al. (1998) verificaram que no sistema plantio direto, ocorreram os maiores coeficientes de variação e os menores alcances de dependência espacial, comparado aos demais sistemas (preparo convencional, escarificação e pastagem), para a maioria das propriedades químicas do solo. Desse modo, assume-se que o solo sob sistema plantio direto é mais variável que o solo sob os demais sistemas estudados pelos autores.

Anghinoni \& Salet (1998) verificaram uma maior variabilidade nas lavouras no sistema plantio direto em relação ao convencional. Segundo estes autores, os coeficientes de variação foram baixos $(<10 \%)$ para $\mathrm{pH}$ e para necessidade de calagem, em ambos sistemas de cultivos. Entretanto, os coeficientes de variação foram altos para fósforo e potássio.

A distribuição de adubos a lanço, através de semeadoras-adubadoras de levante hidráulico, não efetua uma distribuição uniforme na superfície do solo. Essas situações, além de aumentarem a variabilidade horizontal, criam dificuldades para definir a forma e o tamanho (volume) de subamostras para bem representar o sítio de coleta da lavoura (Anghinoni, 2000). 
James \& Wells (1990) caracterizaram a variação horizontal em três tipos: as microvariações que referem-se as variações entre dois pontos separados por distâncias de até $0,50 \mathrm{~m}$ e são resultantes exclusivamente das adubações em linhas; as mesovariações que referem-se aos pontos entre 0,50 e $2,0 \mathrm{~m}$; as macrovariações que referem-se a pontos com distâncias maiores que 2,0 m. nas amostragens de solo, as macrovariações devem ser contempladas pelo número de subamostras, enquanto que as micro e mesovariações devem ser contempladas com o tamanho e local de amostragem.

A colocação do fosfato solúvel, na forma granulada, próximo as linhas de plantio, objetiva aumentar o seu aproveitamento pelas plantas, diminuindo sua adsorção aos óxidos e hidróxidos de ferro e alumínio presentes nos solos altamente intemperizados e com baixo $\mathrm{pH}$. As adubações desuniformes ou feitas em linha favorecem a variabilidade horizontal, pelo fósforo residual, que se mantém disponível por mais de uma cultura (Kitchen et al., 1990; Westfall et al., 1991; Kray et al. 1998).

A variabilidade do potássio não deve estar relacionada somente às linhas de adubação, mas também à localização das plantas, sendo levado da parte aérea para o solo através da chuva, especialmente no final do ciclo (Anghinoni \& Salet, 1998). Dessa forma, o potássio tende a concentrar-se na linha de semeadura, próximo ao colo da planta e diminuir com o afastamento do mesmo (Klepker \& Anghinoni, 1995).

A baixa variabilidade dos índices de matéria orgânica, pH em água e SMP decorre da distribuição uniforme da palhada e do calcário na superfície do solo. Isso, entretanto, não ocorre na aplicação dos adubos, predominantemente em sulcos, que se mantém pouco alterado no tempo(Anghinoni \& Salet, 1998).

O trabalho de Schlindwein \& Anghinoni (2000a), realizado em oito lavouras sob sistema plantio direto consolidado, no Rio Grande do Sul, cujos solos originaram-se de derramamentos basálticos (Latossolo Vermelho distrófico, Latossolo Vermelho distroférrico e Chernossolo Argilúvico férrico), mostrou que é baixa a variabilidade horizontal dos índices de matéria orgânica, pH em água e SMP (solução de sais neutros com vários tampões)(coeficiente de variação menor que 10\%). No entanto, essa variabilidade é elevada para fósforo e potássio disponíveis (Mehlich 1) (coeficiente de variação maior que $30 \%$ ), independentemente do modo de adubação. 
Estudos preliminares demonstram que, em lavouras com adubação a lanço, a variabilidade dos resultados de fósforo e potássio disponíveis decresceu rapidamente com o aumento do tamanho da amostra até $5 \times 10 \mathrm{~cm}$ (espessura x largura) com pá de corte (Anghinoni, 2000).

A variabilidade horizontal da argila é considerada pequena (Libardi et al., 1986), podendo ser muito influenciada pela perda de camadas superficiais, devido a erosão do solo (Albuquerque et al., 1996), sendo muito pouco influenciada por preparos de solo (Souza, 1992).

\subsubsection{Variabilidade vertical}

No sistema convencional de preparo do solo, o manejo da fertilidade, envolvendo a aplicação de fertilizantes e corretivos é facilitado, uma vez que as operações de aração e gradagem promovem a mistura desses insumos na camada superficial do solo (normalmente, 0-20 cm). Entretanto, no sistema plantio direto, uma vez que as operações de revolvimento do solo deixaram de ocorrer, há acúmulo dos resíduos das culturas na superfície, formando um "mulch". Este "mulch" tem contribuído, nessas condições, para melhorar a conservação de água no solo e a estabilidade dos agregados, diminuindo a temperatura do solo e as perdas de partículas de solo e água por erosão hídrica (Sidiras \& Pavan, 1985). Os efeitos do "mulch" nos principais parâmetros da fertilidade resumem-se em acúmulo superficial de carbono orgânico total, aumentos da capacidade de troca catiônica, da soma de bases e dos teores de fósforo na camada superficial do solo, devido à ciclagem de nutrientes pelas coberturas verdes e culturas em rotação.

A formação de uma serapilheira natural na superfície do solo pode proporcionar melhoria nos níveis de fertilidade do solo, destacando aí a importância da matéria orgânica nas reações físico-químicas dos solos (Sidiras \& Pavan, 1985). Assim, é evidente que a deposição de resíduos de culturas em superfície, sem o revolvimento do solo, alteram a taxa de decomposição da matéria orgânica e a liberação de nutrientes, aumentando consideravelmente os teores de carbono e nitrogênio orgânico total, 
principalmente nos primeiros cinco centímetros (Sá, 1993). Com o passar do tempo, esse efeito ocorre progressivamente em profundidade. Isso resulta no aumento da capacidade de troca de cátions, da atividade biológica e dos benefícios decorrentes (Anghinoni \& Salet, 1995).

A decomposição de resíduos e a reação dos adubos nitrogenados na superfície do solo formam uma "frente de acidificação", que aumenta em profundidade, e paralelamente, ocorre aumento do teor de alumínio trocável (Anghinoni \& Salet, 1995). Paralelamente à essa diminuição do pH, ocorre um acúmulo do teor de alumínio trocável e aumento da necessidade de calcário. Por outro lado, também ocorre aumento do alumínio complexado por ácidos orgânicos derivados da decomposição de resíduos culturais. A formação de complexos de Al com ácidos orgânicos pode constituir-se numa maneira estratégica de proteção dos sítios extracelulares das raízes sensíveis à toxicidade de $\mathrm{Al}$ (Miyazawa et al., 1992).

No caso da aplicação de calcário na superfície, sem incorporação, ocorre concentração de cálcio e magnésio trocáveis e elevação do $\mathrm{pH}$, principalmente na camada superficial, e gradativamente, com o passar do tempo, em maiores profundidades. Isso é tão evidente que alguns pesquisadores (Caires et al., 2000) consideram a camada superficial $(0-5 \mathrm{~cm})$ de fundamental importância na recomendação de calagem e na produtividade de culturas no sistema plantio direto já estabelecido.

\subsubsection{Amostragem do solo em sistema de plantio direto}

A amostragem do solo é a etapa inicial, tanto no suporte da pesquisa desenvolvida para a construção de programas de recomendação de adubação e calagem, como também da sua utilização pelo produtor (Anghinoni \& Salet, 1995). Essa etapa é crítica na utilização das recomendações de adubação e calagem, pois os erros (vícios) contidos na amostra não mais poderão ser corrigidos, resultando em recomendações de quantidades insuficientes ou excessivas de insumos, que se refletirão, em qualquer um dos casos, em prejuízos no rendimento das culturas e/ou no lucro do produtor (Anghinoni \& Salet, 1998). 
É de fundamental importância conhecer a variabilidade das características químicas do solo na avaliação da fertilidade para fins de recomendação de adubação (Melsted \& Peck, 1973), desenvolvimento de esquemas de amostragem mais sensíveis e eficientes, e determinação de ótima alocação de unidades de amostragem, para maior eficiência dos delineamentos experimentais (Wilding \& Drees, 1983).

O conhecimento da variabilidade espacial de propriedades químicas do solo fornece subsídios para a coleta de amostras de solo representativas da lavoura. Uma amostra de solo é considerada representativa quando reflete, com alto grau de confiança, as condições de fertilidade do solo da área amostrada (Anghinoni \& Salet, 1995).

A tomada do número certo de subamostras para formar amostra composta é de grande importância. Santos \& Vasconcellos (1987) estudaram 6 ha de um Latossolo Vermelho-Escuro distrófico fase cerrado com objetivo de determinar o número adequado de subamostras de solo para análise química em diferentes condições de manejo. As condições de manejo estudadas foram área recém desmatada, área arada e gradeada e área cultivada com milho após correção do solo, e os critérios de amostragem envolveram amostras simples, amostras compostas formadas por cinco subamostras, amostras compostas formadas por 10 amostras e amostras compostas formadas por 20 subamostras. Os autores verificaram uma redução na variância com aumento no número de subamostras, maior variância em solo arado e gradeado, menores variações para valores de $\mathrm{pH}, \mathrm{Al}$ e matéria orgânica e maiores valores para $\mathrm{P}, \mathrm{Ca}, \mathrm{Mg}$ e $\mathrm{K}$. Assim, quanto maior a ação antrópica, maior a heterogeneidade do solo e maior número de subamostras necessárias (Anghinoni \& Salet, 1995).

No sistema convencional de cultivo ocorrem alterações dos atributos químicos originais, pela aplicação de corretivos e fertilizantes (Santos \& Vasconcellos, 1987). Entretanto, no sistema plantio direto, a variabilidade do solo é aumentada, ainda mais, pela ação residual das linhas de adubação, que se mantêm na seqüência dos cultivos, juntamente com a redistribuição dos nutrientes reciclados dos resíduos (Anghinoni \& Salet, 1998; Souza et al., 1998). Esta variabilidade é caracterizada, também, pela correlação ou dependência espacial, resultante da manutenção das linhas de adubação (intactas), o que requer, também, procedimento estatístico não clássico (por exemplo, 
geoestatística) para o tratamento dos dados (Souza, 1992, citado por Anghinoni \& Salet, 1995). Desse modo, a variabilidade do solo, no sistema plantio direto, é maior do que no preparo convencional, tanto no sentido horizontal como em profundidade no perfil do solo, especialmente nos seus atributos químicos. Até mesmo o instrumento utilizado na amostragem do solo também pode ser fonte de variabilidade, considerando o próprio tamanho (volume de solo) da subamostra, como também possíveis perdas, como, por exemplo, na coleta com trado de rosca, que pode acarretar perdas de solo, principalmente das camadas superficiais, mais ricas em alguns dos atributos químicos do solo (Schlindwein et al., 1998).

Como os índices de fertilidade são alterados em sua magnitude e distribuição no solo, a utilização dos procedimentos recomendados para o preparo convencional do solo dificilmente resultarão na coleta de amostras representativas do estado de fertilidade do solo no sistema plantio direto (Anghinoni, 2000). Assim, os sistemas conservacionistas de manejo, como o plantio direto, criam um ambiente no solo diferentemente daquele verificado no sistema convencional, principalmente, no tocante ao acúmulo superficial de matéria orgânica e de fertilizantes, representando novos desafios para a amostragem do solo (Schulte \& Bundy, 1985; Tyler, 1985).

Devido ao aumento acelerado de áreas cultivadas no sistema plantio direto no Brasil, principalmente nos últimos anos, tem ocorrido, paralelamente, um incremento na demanda de conhecimento sobre a variabilidade dos índices de fertilidade do solo utilizados nas recomendações de adubação e calagem. Esse assunto vem preocupando técnicos e pesquisadores envolvidos nas redes regionais de laboratórios de análises de solos e comissões de fertilidade do solo encarregadas da elaboração das recomendações de adubação (Anghinoni, 2000).

Embora as recomendações sobre a coleta de solo no preparo convencional sejam de domínio amplo, não se sabe, ao certo, que probabilidades de erros, foram dotados para determinar o número de subamostras e assim, conferir, o grau de confiabilidade na representatividade da amostra composta. Uma vez definida esta questão, deve-se determinar o número de subamostras de solo a coletar, tendo em vista a 
natureza e a magnitude da variabilidade horizontal das lavouras no sistema plantio direto (Anghinoni, 2000).

A distribuição superficial uniforme de calcário e da palhada das culturas no sistema plantio direto leva à baixa variabilidade horizontal nos atributos de acidez do solo e nos teores de matéria orgânica, o que determina um pequeno número de subamostras para a coleta de amostras de solo representativas da área (Schlindwein \& Anghinoni, 2000a). Entretanto, as adubações a lanço, quando desuniformes, ou em linhas, favorecem a variabilidade horizontal de nutrientes, como fósforo e potássio, que ficam disponíveis por mais de um cultivo (Klepker \& Anghinoni, 1993). Neste caso, o número de subamostras necessárias para a coleta de amostras representativas da lavoura torna-se maior.

As adubações em sulco, na subsuperfície do solo junto às linhas de semeadura, mantêm uma ação residual prolongada tanto para fósforo como para potássio. A utilização de instrumentos que coletam subamostras pequenas (pequeno volume de solo), como o trado de rosca e calador (diâmetro de 2 a $3 \mathrm{~cm}$ ), geram problemas de representatividade da amostra (Anghinoni, 2000).

Considerando os fatores potenciais de variabilidade no sistema plantio direto, torna-se necessário definir métodos de amostragem representativos quanto ao sítio de coleta, quanto ao tamanho (volume) e quanto ao número de subamostras necessárias para contemplar tal variabilidade dentro de critérios (parâmetros) de confiabilidade estatística (Schlindwein \& Anghinoni, 2000a).

A amostragem de solo para fins de fertilidade deve representar com precisão a sua fertilidade. Normalmente, o solo, por mais uniforme que seja quanto a sua topografia, cor e vegetação, apresenta variações no nível de fertilidade, sugerindo a necessidade de uma amostragem adequada que minimize o erro amostral (Santos \& Vasconcellos, 1987). 


\subsubsection{Local de amostragem do solo em sistema de plantio direto}

A intensidade de amostragem (número de subamostras para formar a amostra composta) é dependente do grau de variabilidade do solo (Anghinoni \& Salet, 1998). Não somente o desmatamento, mas também, o uso do solo com o passar do tempo, conduz ao aumento de sua heterogeneidade (Santos \& Vasconcellos, 1987), principalmente, nos locais onde os fertilizantes têm sido aplicados em faixas ou em linhas (Melsted \& Peck, 1973). Vasconcellos et al. (1982) estudaram o procedimento de amostragem de solo em áreas com adubação fosfatada à lanço e no sulco de semeadura. Os autores verificaram que o teor de $\mathrm{P}$ disponível (Mehlich-1) foi influenciado pela adubação no sulco, sendo que o P foi extraído linearmente com a quantidade de terra proveniente do sulco de semeadura.

Salet et al. citado por Anghinoni \& Salet (1998) observaram que nos locais onde foi realizada amostragem dirigida (uma amostra na linha e quatro amostras nas entrelinhas da cultura anterior - soja) o índice de fósforo (Mehlich-1) na linha foi o triplo do das entrelinhas. Isso demonstrou que a absorção deste nutriente pela soja e aveia preta (cobertura de solo cultivada após a colheita da soja) não foi suficiente para diluir o efeito da localização do adubo da cultura anterior, ou seja, da soja cultivada na safra de verão.

Mediante a enorme variação nos teores de fósforo e potássio no solo, no sentido perpendicular à linha de semeadura, é muito fácil subestimar ou superestimar a necessidade de adubação fosfatada e potássica, através da amostragem aleatória com instrumentos que coletam pequeno volume de solo (trado calador e de rosca, por exemplo). Embora o coeficiente de variação para fósforo tenha sido elevado para ambos os sistemas, plantio direto e convencional, a amostragem dirigida no sistema plantio direto levou a ocorrência de um coeficiente de variação semelhante ao da amostragem aleatória no sistema convencional. Porém, quando a amostragem em sistema de plantio direto não foi dirigida, ou seja, de forma aleatória, o coeficiente de variação para fósforo dobrou. O questionamento, nessa situação, é saber qual a melhor localização do sítio de 
coleta e qual o número de subamostras necessárias para formar um amostra representativa da área com adubação em linha (Anghinoni \& Salet, 1995).

Westfall et al. (1991) propuseram a amostragem dirigida, para contornar os efeitos dos pontos de alta concentração de nutrientes, como alternativa no procedimento de coleta conforme o conhecimento ou não da localização das linhas. Quando a linha é conhecida, propõem-se uma coleta na linha e um número de coletas na entrelinha, de acordo o espaçamento da cultura em polegadas. Quando a localização das linhas não for conhecida, os autores propõem a primeira coleta num local ao acaso na lavoura, e a segunda coleta num ponto que corresponde a metade da distância da entrelinha da cultura, em direção perpendicular às linhas.

Anghinoni \& Salet (1998) fizeram algumas considerações relacionadas à sugestão de amostragem dirigida proposta por Westfall et al. (1991): considerando o espaçamento das entrelinhas de 100, 40 e 17,5 cm para as culturas de milho, soja e trigo, respectivamente, estima-se que o número de subamostras $(n)$ seja $n_{\text {milho }}=26, n_{\text {soja }}=11$ e $n_{\text {trigo }}=5$. Ressalta-se que o número de amostras da entrelinha não está em função somente do espaçamento da cultura. Outros fatores como tipo de solo, extração da cultura, e, principalmente, as quantidades de fertilizantes utilizadas na cultura anterior alteram o fator $n$ (número de subamostras). Assim, as amostragens dirigidas, levando-se em consideração somente o espaçamento da cultura anterior, não é uma proposta sustentável de amostragem de solo.

Mahler citado por James \& Hurst (1995), menciona que recomendações de amostragem variam consideravelmente considerando adubação em linha, comparando sistemas de amostragem (séries de amostras coletadas perpendicularmente às linhas de plantio) sem aleatorização (evitando contato com as linhas) e completamente casualizadas, constatou que amostragem aleatorizada é mais viável pois apresenta menor custo. Tylor \& Howard citados por James \& Hurst (1995) verificaram que aleatorização na amostragem é mais viável pois evita superestimação resultante do fertilizante aplicado nas linhas.

Kitchen et al. citados por James \& Hurst (1995) mencionam que relação entre amostras da linha e entrelinha devem representar o solo todo. Concluíram que número 
inadequado de subamostras da linha adubada pode superestimar P e subestimar a sua necessidade. Segundo Westfall et al. (1991), não é possível tomar subamostras suficientes para obter análise precisa se altas taxas de P são aplicadas nas linhas.

Ashworth (1991) citado por James \& Hurst (1995) descreve amostrador portátil que corta fatia de solo através da linha adubada, mistura amostra da linha ao restante de solo, e aleatoriza os pontos amostrados. Porém não existem dados que mostrem a eficiência ou eficácia do amostrador. Amostras foram tomadas nas linhas com furos de $2 \mathrm{~cm}$ a $25 \mathrm{~cm}$ de profundidade para refletir a última adubação aplicada. Amostrou-se 20 padrões aleatoriamente em área adubada em linha. Obteve-se amostra composta a partir da média de todas subamostras, resultados das amostras compostas simulam linhas adubadas com fósforo através da mistura das subamostras de linha e entrelinha.

A adubação fosfatada em linha cria dois padrões de concentração de fósforo, um na linha e outro na entrelinha, então a amostragem deve ser realizada de modo a ser representativa. Pontos de amostragem devem contemplar uma linha perpendicular à linha adubada, porém este procedimento é trabalhoso. $\mathrm{O}$ uso de equipamento que possa cortar facilmente uma fatia de solo através da linha adubada a uma profundidade e comprimento necessários para amostragem deve ser melhor estudado (James \& Hurst, 1995).

Os manuais dos diversos Programas de Adubação e Calagem, elaborados regionalmente no Brasil, pelas respectivas Comissões de Fertilidade do Solo (Anghinoni \& Volkweiss, 1984), recomendam coletar em torno de 20 subamostras para formar cada amostra composta e representativa de determinada área homogênea no sistema convencional de preparo do solo. Tais recomendações se referem a subamostras pequenas, normalmente coletadas com trado de rosca, calador (diâmetro de 2 a $3 \mathrm{~cm}$ ) ou a parte central da fatia retirada com pá de corte (em torno de 2,5 e 5,0 cm de espessura e largura, respectivamente).

A definição do número de subamostras a coletar, visando atender às recomendações de adubação e calagem, deve considerar a variabilidade de todos os 
índices de fertilidade do solo, incluídos no programa (Schlindwein \& Anghinoni, 2000a), inclusive os índices de fertilidade com a maior variabilidade horizontal.

A Comissão de Fertilidade do Solo (1995) recomenda, para sistema plantio direto com adubação a lanço, a coleta de 20 subamostras, coletadas de forma aleatória com trado, calador ou pá de corte (parte central), originando-se subamostras pequenas (pequeno volume); e para lavouras no sistema plantio direto com adubação em linhas, recomenda-se em torno de oito subamostras na largura da entrelinha, coletadas com pá de corte, originando-se subamostras grandes.

Para contornar os problemas gerados pela continuidade das linhas de adubação (efeito residual) e que o sítio de coleta represente bem a sua área de alcance, a Comissão de Fertilidade do Solo (1995) recomenda a coleta de uma secção transversal às linhas de semeadura, com espessura de 3 a $5 \mathrm{~cm}$, na largura das entrelinhas da última cultura.

No trabalho de Schlindwein et al. (1998), o coeficiente de variação do fósforo disponível, em lavoura com 12 anos no sistema plantio direto e adubação em sulcos, foi mais elevado, 67\%, na amostragem com trado de rosca do que com pá de corte $(5 \times 10$ $\mathrm{cm}$, de espessura x largura da amostra, respectivamente), que foi $33 \%$. Essa diferença foi atribuída à perda de solo da camada superficial, mais rica em fósforo. Ainda, segundo Anghinoni \& Salet (1998), quando se utiliza o trado tipo rosca, é difícil de se coletar, em condições de baixos teores de umidade, a parte superior do solo $(0$ a $1,5 \mathrm{~cm})$. Isso resultou da necessidade de se coletar um número muito maior de subamostras com trado de rosca em relação ao número de subamostras coletadas com pá de corte, independentemente do erro admitido em relação à média. Em lavoura com adubação a lanço, os mesmos autores verificaram que o coeficiente de variação foi menor na amostragem com trado de rosca (47\%), enquanto que, para a amostragem com pá de corte, o coeficiente de variação foi semelhante ao obtido em lavoura com adubação em sulcos, e assim, o número de subamostras permaneceu em 44. Assim, a amostragem do solo com trado de rosca resulta na coleta de um número elevado de subamostras para os limites de precisão adotados, independentemente do modo de adubação utilizado. 
Além dos erros de amostragem, Schlindwein \& Anghinoni (2000a) ressaltaram a possibilidade de ocorrência de problemas em laboratório, inerentes às instalações, equipamentos, pessoal e limitações dos próprios métodos de análise. Deste modo, como há possibilidades de ocorrer outros erros, além dos inerentes à amostragem, nas diferentes etapas do processo de recomendações de adubação e calagem pelos laboratórios, muitas vezes de grande repercussão na definição das doses desses insumos por aplicar os limites de precisão utilizados (probabilidade $(\alpha)=0,05$ e erro em torno da média $(e)=10 \%$ ) nas pesquisas (Santos \& Vasconcellos, 1987; Souza et al., 1998) para determinar o número de subamostras, podem ser demasiadamente exigentes para as condições de lavoura. A opção de utilizar $\alpha=0,05$ e erro $e=20 \%$ apresentou um número médio de 13 e 11 subamostras para fósforo e potássio, respectivamente, com variação, para ambos, de 3 a 24 subamostras (Schlindwein \& Anghinoni, 2000a).

Schlindwein \& Anghinoni (2000a) verificaram a importância da coleta de subamostras que contemplem a variabilidade do sítio de coleta e ao mesmo tempo, a retirada de um número relativamente menor de subamostras representativas, admitindose um erro de $20 \%$ em relação a média. Para tanto, coletaram-se aleatoriamente 13 valores de fósforo disponível do conjunto de 36 amostras simples de cada lavoura (incluindo lavouras com diferentes tempos de cultivo no sistema plantio direto e diferentes faixas de teores de fósforo no solo) e calculadas as respectivas médias. Esses valores foram então comparados com a média dos valores das 36 amostras simples de cada lavoura, para verificar o enquadramento de ambos nas faixas de interpretação desse nutriente para fins de recomendação de adubação, conforme adotado pela Comissão de Fertilidade do Solo (1995). Os autores verificaram que a utilização de 13 subamostras para o cálculo da média não alterou as faixas de interpretação dos resultados em relação ao enquadramento das médias resultantes de 36 amostras simples.

Desse modo, o número de subamostras (20), preconizado para a coleta de amostras no sistema convencional de cultivo, admite um erro de $20 \%$ em relação à média no sistema plantio direto, não altera as faixas de interpretação dos resultados e as respectivas recomendações de adubação nesse sistema de cultivo. Essas observações são 
válidas desde que a representatividade do sítio de coleta seja atendida (Schlindwein \& Anghinoni, 2000a).

\subsubsection{Profundidade de amostragem do solo em sistema de plantio direto}

As recomendações de adubação e de calagem, em uso no Brasil, foram construídas para o sistema convencional de preparo do solo, considerando os índices de fertilidade de amostras de solo retiradas da camada mobilizada (arável), geralmente, de 0-20 cm. Entretanto, mediante a utilização do sistema plantio direto, ocorrem alterações significativas nas propriedades químicas, físicas e biológicas do solo, em comparação ao sistema convencional, que, por sua vez, afetam consideravelmente os índices de fertilidade, alterando as recomendações de adubação e de calagem (Anghinoni \& Salet, 1998).

Devido à similaridade da configuração das curvas de rendimento das culturas nos sistemas plantio direto e convencional, a dinâmica de estabelecimento, os elevados custos e tempo de obtenção das curvas de calibração no sistema plantio direto, levaram à procura de alternativas de ajuste em relação ao sistema convencional, ao invés de construir novas tabelas para o sistema plantio direto. Dentre as alternativas sugeridas (Anghinoni \& Salet, 1998), o ajuste da profundidade de amostragem, que se baseia na similaridade de rendimento das culturas nos dois sistemas, demonstrada por Petrere et al. (1996) para diversas situações de solo e culturas no sul do brasil, mostrou ser a alternativa mais prática e viável em curto prazo. Essa alternativa é apropriada para o ajuste da recomendação de nutrientes que formam gradientes que decrescem a partir da superfície do solo. Para o ajuste, deve-se determinar a profundidade de amostragem no sistema de plantio direto que apresente os mesmos valores dos índices, no caso do fósforo e potássio disponíveis, da camada de $0-20 \mathrm{~cm}$ do sistema convencional, ambos com o mesmo manejo. De posse dos resultados de análise do solo nessa profundidade, pode-se utilizar as tabelas de recomendação de adubação elaborada no sistema convencional. 
Os exemplos de ajuste para esses índices tiveram mais um valor demonstrativo da metodologia do que propriamente o de uma recomendação de profundidade de uso em geral. Inobstante a isso, e pela necessidade de atender a forte demanda do setor de produção, houve uma recomendação preliminar da Comissão de Fertilidade do Solo do Núcleo Regional Sul da Sociedade Brasileira de Ciência do Solo de coletar amostras de solo da camada de 0-10 $\mathrm{cm}$ no sistema plantio direto consolidado (mais de 5 anos), para servir de base para recomendações nesse sistema (Anghinoni \& Salet, 1998).

A formação de um gradiente vertical de teor de nutrientes no solo (variabilidade vertical) gera dificuldades para definir procedimentos de amostragem que reflitam o estado de fertilidade do solo. Dessa forma, uma amostra de solo retirada da camada 0-20 cm de profundidade, recomendada para o sistema convencional, pode não ser adequada para representar o estado de fertilidade do solo no sistema plantio direto (Schlindwein \& Anghinoni, 2000b). Por exemplo, a mistura das camadas superiores (02,5 ou 0-5,0 cm) com maior teor de fósforo, com camadas inferiores $(15-20 \mathrm{~cm})$ as quais, normalmente, possuem menores teores desse nutriente, pode terminar um decréscimo proporcionalmente maior nos valores da análise (Anghinoni \& Salet, 1998). O decréscimo se dá tanto pelo efeito diluição como pela "fixação" do fósforo em solos com maiores teores de óxidos de ferro e alumínio e em presença de gradiente textural elevado (Schlindwein \& Anghinoni, 2000b).

Evidências relativas à configuração das curvas de rendimento das culturas no sistema plantio direto, comparadas às do sistema convencional de cultivo, em função das doses de adubos aplicados, à dinâmica do estabelecimento, aos elevados custos e tempo de obtenção de novas curvas de calibração (e das tabelas de adubação) para o sistema plantio direto, levaram a procura de alternativas de ajuste ao sistema convencional, ao invés de se construir novas tabelas de adubação para o sistema plantio direto (Anghinoni, 2000). A similaridade dos rendimentos das diferentes culturas e/ou suas sucessões nos dois sistemas em diferentes locais e solo no Sul do Brasil (Petrene et al. citado por Anghinoni, 2000), indicam para a alternativa de ajuste de profundidade de amostragem no sistema plantio direto como a prática mais viável a curto prazo. Para o 
ajuste, determina-se a profundidade de amostragem no sistema plantio direto que apresente os mesmos valores dos índices de fertilidade da camada $020 \mathrm{~cm}$ no preparo convencional. De posse dos resultados de análise do solo nessa profundidade, utiliza-se às tabelas de adubação do sistema convencional para as recomendações no sistema plantio direto (Anghinoni, 2000).

Estudando a variabilidade vertical (Schlindwein \& Anghinoni, 2000b), realizaram estudo com objetivo de definir profundidade ideal de amostragem no sistema plantio direto para fins de recomendações de adubação para P e K. Alterações referentes à profundidade de amostragem em sistema plantio direto podem ser necessárias em função da ocorrência de variabilidade vertical.

Comparando sistema convencional e plantio direto, Schlindwein \& Anghinoni (2000b) não encontraram diferenciação em produtividade no decorrer de várias safras. Considerando a não diferença em produtividade, os autores verificaram condição ideal para utilizar parâmetros de fertilidade no ajuste da profundidade de amostragem.

Realizando-se regressão quadrática relacionando profundidade do solo com os valores de nutrientes no plantio direto, tornou-se impossível estimar a profundidade de amostragem. Substituiu-se em cada equação, o valor de análise do nutriente da camada de 0-20 cm do sistema convencional e obteve-se o valor correspondente da profundidade de amostragem no sistema plantio direto (Schlindwein \& Anghinoni, 2000b).

Recomendações de $\mathrm{P}$ e $\mathrm{K}$ baseadas em amostragem de 0-10 cm em Latossolo Vermelho distrófico, sob plantio direto até 10 anos, com níveis adequados desses nutrientes, não diferenciaram das recomendações baseadas na coleta de amostras mais superficiais, resultando em rendimentos iguais de milho.

Então, depois de constatada a similaridade dos rendimentos de culturas de quatro áreas experimentais nos sistemas plantio direto e convencional, com mesmo histórico em diferentes regiões do Rio Grande do Sul, Schlindwein \& Anghinoni (2000b) adotaram a metodologia do ajuste de profundidade de amostragem para fósforo e potássio disponíveis. O ajuste, apesar de se mostrar viável, conforme verificado anteriormente por Anghinoni \& Salet (1998), somente se justificou quando os teores dos nutrientes encontravam-se abaixo dos níveis críticos das culturas. E portanto, esse fato 
ocorreu somente em um dos locais experimentais. A profundidade ajustada foi de aproximadamente de sete centímetros, para ambos nutrientes (fósforo e potássio), ou seja, um pouco menor que a recomendação anterior (10 centímetros) de Anghinoni \& Salet (1998). Entretanto, nos solos com teores elevados desses nutrientes, a amostragem em qualquer profundidade até $20 \mathrm{~cm}$, não alterou as recomendações de adubação.

Evidentemente, os resultados do trabalho de Schlindwein \& Anghinoni (2000b) indicaram a necessidade de utilizar experimentos com teores de fósforo e potássio disponíveis abaixo da faixa suficiente (nível crítico), para maior conhecimento da variabilidade vertical do solo, em diferentes condições de manejo da fertilidade e desse modo, definir a melhor maneira de representar o real estado de fertilidade do solo no sistema plantio direto.

Algumas pesquisas já realizadas demonstraram que a amostragem de solo na camada de $0-10 \mathrm{~cm}$ de profundidade no sistema de plantio direto apresentaram valores semelhantes aos do sistema convencional com arado para o $\mathrm{pH}, \mathrm{Ca}, \mathrm{Mg}$ e $\mathrm{K}$, e valores semelhantes ao sistema com grade aradora para o $\mathrm{pH}, \mathrm{Ca}, \mathrm{P}$ e K. Já para a profundidade de 10-20 cm, o P apresentou valores semelhantes ao do preparo convencional (Silveira \& Stone, 2002).

As informações disponíveis no Sul de país sobre as questões advindas da variabilidade do solo no sistema plantio direto já permitem algumas recomendações de ordem prática. Para contornar os problemas gerados pela continuidade das linhas de adubação, efeito residual, e que o sítio de coleta represente a sua área de alcance, a Comissão de Fertilidade do Solo RS/SC (Comissão, 1995) recomenda a coleta de uma secção transversal às linhas de semeadura, com espessura de 3 a $5 \mathrm{~cm}$, na largura das entrelinhas da última cultura.

Muitos questionamentos têm surgido no meio técnico, especialmente para nutrientes que formam gradientes acentuados, como o fósforo, necessitando então, elaborar recomendações diferenciadas para o sistema de plantio direto desde a sua implantação ou buscar alternativas de ajuste em relação ao preparo convencional (Anghinoni, 2000). 


\subsection{Avaliação da disponibilidade de fósforo em sistema de plantio direto}

Segundo Tisdale et al. (1993) os teores de fósforo no solo variam de 0,02 a 0,10\% do peso seco, encontrando-se, portanto, em menor abundância do que o nitrogênio. Ele encontra-se predominantemente na forma de íon ortofosfato $\left(\mathrm{H}_{2} \mathrm{PO}_{4}{ }^{-}\right)$, sendo pouco móvel, e em baixos teores na forma livre na solução do solo. Este elemento ocorre quase todo em formas lábil ou não lábil, como no húmus, ou fixado a colóides minerais. De acordo com Cantarella et al. (1992), de 2/3 a $1 / 2$ do fósforo total no horizonte superficial do solo encontra-se na forma orgânica. Normalmente o aumento nos teores de fósforo inorgânico e o decréscimo no fósforo orgânico, devido aos anos seguidos de cultivo, promovem uma queda na fertilidade do solo. Este processo, no entanto, pode ser revertido através de práticas agrícolas conservacionistas, como o plantio direto, que aumentem os teores de matéria orgânica e, consequentemente, da fração orgânica do fósforo.

O fósforo é um dos macronutrientes com menor mobilidade. Permanece no local em que é colocado e não é diluído e transportado no perfil do solo pela água da chuva. Ele pode ser incorporado através do transporte por insetos, minhocas e outros animais e pela erosão vertical nas rachaduras e nas galerias. É um dos elementos de maior importância nos solos brasileiros, em geral, em níveis baixos. Em campos e matas nativas e sob plantio direto, encontra-se em maior quantidade na superfície do solo. Sob plantio direto, quando aplicado na linha de semeadura, apresenta acentuadas variações em seus teores quando analisado diferentes amostras na camada até $5 \mathrm{~cm}$ de profundidade. Essa concentração na camada superficial não causa preocupação, pois as raízes desenvolvem-se nesse ambiente e na superfície, quando há palha em abundância.

Weil et al. (1988) observaram que o acúmulo de fósforo orgânico, ao contrário do nitrogênio orgânico, não guardou relação com o aumento da quantidade de matéria orgânica adicionada ao solo nas condições de plantio direto. Eles constataram também, com a incubação de resíduos vegetais, que a mineralização do fósforo orgânico não promoveu aumento significativo do fósforo disponível no solo. 


\subsubsection{Aplicação de fósforo no solo}

O fósforo (P) encontra-se no solo em diversos tipos de ligações químicas, principalmente em compostos de ferro, alumínio, cálcio e na matéria orgânica (Raij \& Feitosa, 1980). Estas formas de fósforo existem na dependência do $\mathrm{pH}$ dos solos, dos produtos de solubilidade dos fosfatos, dos cátions presentes nos solos e do grau de intemperização (Chang \& Jackson,1958; Fassbender et al., 1968; Vasconcellos et al., 1975). As formas inorgânicas de fósforo mais conhecidas em solos ácidos são as de fósforo ligado ao ferro e ao alumínio. O fósforo solúvel, adicionado ao solo como fertilizante, pode assumir diversas formas, sendo agrupados como P-solúvel, P-Al, P-Fe, $\mathrm{P}-\mathrm{Ca}$, fosfatos oclusos de ferro e alumínio e $\mathrm{P}$ sob formas orgânicas. À medida que os solos se tornam mais ácidos, a atividade do ferro e do alumínio aumenta e as formas mais solúveis de P-Ca são convertidas em P-Al e P-Fe (Chang \& Jackson,1958).

Em média, $90 \%$ do fósforo aplicado como fertilizante inicialmente não é absorvido diretamente pelos vegetais (Tisdale et al., 1993), pois, segundo Raij (1991) este forma complexos pouco solúveis com óxidos de ferro e de alumínio, causando uma

carência generalizada deste elemento nos solos do Brasil. É importante ressaltar que o fósforo orgânico é adsorvido preferencialmente em relação ao fósforo inorgânico, tendo assim um efeito benéfico indireto, ao aumentar a disponibilidade do fósforo mineral no solo (Cantarella et al., 1992).

O comportamento do fósforo no plantio direto difere em relação ao preparo convencional em três pontos básicos, o não revolvimento do solo que reduz o contato do íon fosfato com os colóides do solo, amenizando as reações de adsorção; a manutenção de resíduos vegetais sem a sua incorporação ao solo que resulta na formação de linhas com maior concentração de fósforo para fertilização das culturas; e a mineralização lenta e gradual dos resíduos proporciona a liberação e redistribuição de formas orgânicas e fósforo mais estáveis e menos suscetíveis às reações de adsorção (Sá, 1999).

Pottker (1995) recomenda que antes de adotar o sistema de plantio direto, os agricultores devem aplicar fertilizantes fosfatados a lanço fazendo a incorporação dos 
mesmo na camada arável. As aplicações posteriores podem então serem feitas nas linhas de semeadura ou a lanço, na superfície do solo.

Triplett \& Doren van (1969), revisando a literatura sobre a utilização de fósforo na cultura do milho no sistema plantio direto, constaram que alguns pesquisadores encontraram resposta satisfatória para a aplicação do fósforo a lanço sobre resíduos culturais. Entretanto, alguns desses trabalhos foram desenvolvidos em áreas com elevado teor de fósforo ou com baixos níveis de produtividade. Em outra situação, Eckert et al., (1985), trabalhando com solos de Ohio (EUA), obtiveram maior rendimento de grãos de milho e elevado coeficiente de recuperação do fósforo com a aplicação no sulco de semeadura. Em seus experimento com aplicação de fósforo no sulco e à lanço, em um solos com alto teor de fósforo $\left(13,6 \mathrm{mg} \mathrm{dm}^{-3}\right)$ e $420 \mathrm{~g} \mathrm{~kg}^{-1} \mathrm{de}$ argila e outro com teor médio de fósforo $\left(4,3 \mathrm{mg} \mathrm{dm}^{-3}\right)$ e $360 \mathrm{~g} \mathrm{~kg}^{-1}$ de argila , Pottker (1995) observou que em ambos os solos a aplicação de fósforo nas linhas de semeadura foram mais eficientes que a aplicação a lanço.

\subsubsection{Distribuição de fósforo no solo}

A quantidade de fósforo na superfície varia com o solo, a dose aplicada e o tempo de adoção do plantio direto. Em geral, os níveis mais elevados são observados na camada até $10 \mathrm{~cm}$ de profundidade. É importante destacar que sob plantio direto a disponibilidade de $\mathrm{P}$, apesar de concentrado na superfície, é maior do que sob plantio convencional, após vários anos com doses aplicadas equivalentes. Isto confirma observações de agricultores que reduzem as doses de fertilizantes após alguns anos sob plantio direto.

A ocorrência de maiores concentrações de fósforo nas camadas superiores do solo no sistema de plantio direto é relatada por diversos autores. Doran (1980), Helal \& Sauerbek (1984) e Ball-Coelho et al. (1993), constataram maiores teores de fósforo nas camadas mais superficiais do solo sob plantio direto, atribuindo isso à influência das raízes que induziram o aumento da atividade microbiana na região, assim como de 
microrganismos solubilizadores de fosfato e da atividade da enzima fosfatase, o que culmina numa reciclagem mais eficiente do elemento.

Shear \& Moschler (1969), comparando o milho sob plantio direto ao sob preparo convencional, observaram que na camada de 0 a $5 \mathrm{~cm}$ de profundidade os teores de fósforo disponível foram 4 vezes superiores no plantio direto $\left(242 \mathrm{mg} \mathrm{dm}^{-3}\right)$, do que no plantio convencional $\left(63 \mathrm{mg} \mathrm{dm}^{-3}\right)$. Na camada logo abaixo $(5 \mathrm{a} 10 \mathrm{~cm})$, no entanto, os teores no plantio direto foram aproximadamente 10 vezes menores $\left(21 \mathrm{mg} \mathrm{dm}^{-3}\right)$, enquanto que no preparo convencional os teores sofreram diminuição mais suave de $30 \%\left(44 \mathrm{mg} \mathrm{dm}^{-3}\right)$, passando a apresentar, portanto, os valores mais elevados.

Sá (1993) encontrou num Latossolo Vermelho-Escuro há 4 anos sob plantio direto em Carambeí (PR), teores de fósforo em maiores concentrações na camada de 0 a $2,5 \mathrm{~cm}\left(28,8 \mathrm{mg} \mathrm{dm}^{-3}\right)$, constatando queda nos teores desta para a profundidade de 2,5 a $5,0 \mathrm{~cm}\left(17,9 \mathrm{mg} \mathrm{dm}^{-3}\right)$. No entanto, em profundidades maiores do que $10 \mathrm{~cm}$, o autor encontrou outra queda nestes valores quando eles foram de 2,9 (até $20 \mathrm{~cm}$ ) para 0,9 mg $\mathrm{dm}^{-3}$ (abaixo de $30 \mathrm{~cm}$ ). Este autor ressaltou a importância de se efetuar amostragens mais estratificadas em solos sob plantio direto para se evitar o efeito de diluição, devido aos valores muito menores encontrados a maiores profundidades.

Moschler et al. (1975) afirmaram que a ocorrência de maiores concentrações de fósforo na superfície no plantio direto s deve principalmente ao não revolvimento do solo, o que por sua vez causaria uma menor exposição do fósforo aos sítios de adsorção na superfície dos minerais, assim como à maior umidade que o sistema proporciona facilitando a difusão deste elemento. Unger et al. (1991) concluíram que os maiores teores do mesmo na superfície se deveram a natureza pouco móvel do elemento, fazendo com que ele permaneça próximo à região onde foi mineralizado, quando da decomposição da palhada.

Segundo Thomas et al. (1981) e Raij (1981), o maior acúmulo de fósforo nas camadas superficiais do solo sob plantio direto se explica pela baixa mobilidade de seus compostos, sobretudo em solos de natureza ácida e contendo altos teores de argila e sesquióxidos de $\mathrm{Fe}$ e Al. O maior contato entre o adubo e as partículas do solo, promovido pela movimentação do solo por ocasião do preparo, explica a menor 
disponibilidade do nutriente em plantio convencional e seu comportamento, quanto à distribuição na camada arável.

Phillips (1984) relataram que a maior eficiência de aproveitamento de fósforo pelas culturas em plantio direto, se deve também ao fato de que a camada superficial do solo, imediatamente abaixo da cobertura morta formada pelos resíduos mantidos sobre a superfície do terreno, apresenta maior teor de umidade a favorecer a taxa de difusão do fósforo até as raízes.

\subsubsection{Métodos de avaliação da disponibilidade de fósforo}

O conhecimento dos níveis críticos dos nutrientes no solo possibilita uma recomendação mais precisa da adubação. O nível crítico corresponde ao teor de elemento no solo abaixo do qual a taxa de crescimento ou a produção vegetal diminui significativamente, demonstrando a necessidade de adubação complementar (Raij \& Feitosa, 1980).

As plantas absorvem o fósforo da solução do solo. Os teores de fósforo na solução do solo são sempre muito baixos e, à medida que ocorre depleção com a absorção pelas raízes das plantas, ocorre reposição através do fósforo de formas sólidas que se encontram em equilíbrio com o fósforo da fase liquida. $\mathrm{O}$ fósforo da fase sólida que está em equilíbrio como fósforo da fase líquida é chamado de "fósforo lábil" (Raij \& Feitosa, 1980).

Os autores ainda relatam que uma das dificuldades da escolha de um método para avaliar a disponibilidade de fósforo para a planta é que não há uma transição clara entre o fósforo lábil e o não-lábil dos solos. Além disso, o fósforo encontra-se em diversos tipos de ligações químicas, principalmente em compostos de ferro, alumínio, cálcio e na matéria orgânica.

Os vários métodos de extração de fósforo existente, reflete a complexidade do seu comportamento no solo, bem como da falta de concordância sobre qual seria o método de avaliação mais adequado (Vale et al., 1998). Segundo Raij (1978) reafirmado por Novais et al., (1986), o uso de extratores químicos que possuem variadas 
composições e formas de atuação podem gerar valores que não correspondem ao fósforo que efetivamente é colocado à disposição das plantas.

A maioria desses métodos empregam soluções ácidas, básicas e sais, ou ainda, mistura de ambas, que removem frações ou partes proporcionais do fósforo do solo. A escolha de um ou de outro método depende diretamente da capacidade deste em extrair formas e quantidades do nutriente que se relacionam com as absorvidas pelas plantas, medida pelo coeficiente de determinação $\left(\mathrm{r}^{2}\right)$ em modelos gráficos ou equações matemáticas. Essa capacidade depende fundamentalmente das propriedades de cada solo, que influenciam diretamente na dinâmica dos nutrientes (Thurow et al., 2002).

Entre os métodos mais utilizados no Brasil para determinar o teor de fósforo no solo podemos citar o Mehlich-1 (Olsen \& Dean, 1960) e o da resina trocadora de íons (Raij \& Quaggio, 1986) ambos citados em Vale et al. (1998).

O método da Resina extrai o fósforo da solução do solo, que está em equilíbrio com o fósforo da fase sólida do solo. Assim, ao longo do tempo e agitação, o método tem condições de extrair todo ou parte do fósforo lábil ou disponível para as plantas, sem afetar significativamente as principais propriedades do solo, ou seja, os reagentes utilizados no método apenas tamponam o meio de extração entre pH 6,0 e 7,0 (semelhante ao $\mathrm{pH}$ de absorção de nutrientes pelas plantas), diferentemente dos demais extratores que modificam significativamente o $\mathrm{pH}$ e provocam dissolução e/ou complexação de compostos. Por estas características, a resina é considerada o método mais eficiente de extração de fósforo e que mais se assemelha com os princípios de remoção de fósforo do solo pelas plantas (Raij, 1991; Thurow et al., 2002).

Todavia , o método da Resina é submetida a uma restrição na total dessorção do fósforo lábil, particularmente em solos com altos valores do fator de capacidade de fósforo no solo, subestimando o valor total do fósforo disponível. Este efeito do fator de capacidade de fósforo no solo restringir, parcialmente, a dessorção do fósforo lábil pela resina é bem menor do que o desgaste de extratores, como o Mehlich-1. Portanto, erros na estimativa do valor de fósforo disponível, à medida que o fator capacidade do fósforo no solo aumenta, são maiores para os extratores sensíveis a este efeito do que o método da Resina (Novais \& Smyth, 1999). 
A solução extratora de Mehlich-1, também chamada de duplo-ácida ou de Carolina do Norte, é constituída por mistura de $\mathrm{HCl} 0,05 \mathrm{M}+\mathrm{H}_{2} \mathrm{SO}_{4}$ 0,0125 M. O emprego dessa solução como extratora de fósforo baseia-se na solubilização desses elementos pelo efeito do $\mathrm{pH}$, entre 2 e 3 , sendo o papel do $\mathrm{Cl}$ o de restringir o processo de readsorção dos fosfatos recém extraídos. Tem como vantagem a facilidade na obtenção de extratos límpidos por decantação, baixo custo e simplicidade operacional (Embrapa, 1999).

Para este método tem sido observado valores subestimados do fósforo disponível com maior frequiência em solos argilosos, de modo especial naqueles com $\mathrm{pH}$ mais elevado, em razão de ser o seu poder de extração desgastado pelo próprio solo. Nesses solos mais argilosos, com acidez mais tamponada, o pH inicial do Mehlich-1 é rapidamente elevado para valores de $\mathrm{pH}$ próximos ao do solo. Igualmente, $\mathrm{o} \mathrm{SO}_{4}{ }^{-2}$ do extrator, que atua por troca com o fosfato adsorvido, é também, rapidamente adsorvido pelo solo em sítios ainda não ocupados pelo fósforo, perdendo o poder de extração (Novais \& Kamprath, 1979). Assim, em solos argilosos, os valores dos níveis críticos são menores do que nos arenosos, porque naqueles o extrator é bem mais desgastado que nestes (Freire et al.., 1979). Por outro lado, para esse mesmo extrator, valores superestimados de fósforo disponível são verificados em solos com predomínio de fósforo ligado à cálcio (Novelino et al., 1985).

Existem poucos trabalhos sobre a eficiência dos métodos de avaliação da disponibilização de fósforo em sistema de plantio direto, principalmente, visando calibração para fins de recomendação de adubação fosfatada, envolvendo métodos de amostragem de solo. 


\section{MATERIAL E MÉTODOS}

\subsection{Localização e características da área experimental}

O experimento foi instalado em área pertencente a Fundação MS (Mato Grosso do Sul), localizada no município de Maracajú - MS, cujas coordenadas geográficas são $21^{\circ} 00^{\prime} \mathrm{S}$ e $55^{\circ} 42^{\prime} \mathrm{W}$. A altitude é de aproximadamente $384 \mathrm{~m}$ e o relevo levemente ondulado. As precipitações médias anuais variam de 1500 a 1700 mm com um período seco inferior a quatro meses. As temperaturas médias no verão estão entre 25 e $27{ }^{\circ} \mathrm{C}$, e as máximas entre 30 e $33{ }^{\circ} \mathrm{C}$. As médias do mês mais frio estão entre 14 e $15{ }^{\circ} \mathrm{C}$, as mínimas absolutas de inverno ficam entre 4 e $6{ }^{\circ} \mathrm{C}$, registrando-se ocorrência de geada. Apresenta um clima tipo Aw, segundo classificação de Köppen.

O solo, no qual o experimento foi instalado, foi caracterizado como Latossolo Vermelho Distrófico (BRASIL, 1999). Os resultados de análise química do solo antes da instalação do experimento, de acordo com a metodologia descrita por Raij \& Quaggio (1983) (para P-Resina) e pela Embrapa (1999) (para os demais parâmetros), encontramse na tabela 1. 
Tabela 1. Resultado da análise do solo antes da implantação do experimento (06/09/2000).

\begin{tabular}{|c|c|c|c|c|c|c|c|c|c|c|c|}
\hline Prof. & \multicolumn{2}{|c|}{$\overline{\mathrm{pH}}$} & MO & P Mehli & & P Resina & $\mathbf{K}$ & $\mathbf{C a}$ & Mg & Al & $\mathrm{H}+\mathrm{Al}$ \\
\hline$(\mathrm{cm})$ & $\mathrm{CaCl}_{2}$ & $\mathrm{H}_{2} \mathrm{O}$ & g. $\mathrm{dm}^{-3}$ & \multicolumn{3}{|c|}{$\mathrm{mg} \cdot \mathrm{dm}^{-3}$} & & $n$ & $\mathrm{~mol}_{\mathrm{dm}} \mathrm{dm}$ & & -- \\
\hline $0-10$ & 5,4 & 6,1 & 38,0 & 3,0 & & 7,0 & 1,8 & 51,0 & 18,0 & 0,0 & 29,0 \\
\hline $10-20$ & 5,0 & 5,7 & 29,0 & 2,0 & & 5,0 & 0,8 & 40,0 & 10,0 & 0,0 & 36,0 \\
\hline $0-20$ & 5,2 & 5,9 & 33,5 & 2,5 & & 6,0 & 1,3 & 45,5 & 14,0 & 0,0 & 32,5 \\
\hline Prof. & SB & $\mathbf{T}$ & V & Argila & $\mathbf{S}$ & $\mathbf{Z n}$ & B & $\mathrm{Cu}$ & Mn & $\mathrm{Fe}$ & $\mathrm{Na}$ \\
\hline$(\mathrm{cm})$ & \multicolumn{2}{|c|}{$\mathrm{mmol}_{\mathrm{c}} \mathrm{dm}^{-3}$} & $(\%)$ & $(\%)$ & & & & $\mathrm{mg} \mathrm{dm}$ & & & \\
\hline $0-10$ & 70,8 & 99,8 & 70,94 & 56,9 & 4,0 & 4,2 & 0,2 & 4,0 & 44,0 & 106,0 & 8,5 \\
\hline $10-20$ & 50,8 & 86,8 & 58,53 & --- & 4,2 & 1 , & 0,2 & 3,8 & 19,0 & 112,5 & 5,2 \\
\hline $0-20$ & 60,8 & 93,3 & 64,74 & --- & 4,1 & 2,85 & 0,2 & 3,9 & 31,5 & 109,25 & 6,85 \\
\hline
\end{tabular}

Metodologia: $\quad \mathrm{P} \rightarrow$ Mehlich-1 e Resina; K, Na, Fe, Mn, Cu e Zn $\rightarrow$ Mehlich 1:10;

$\mathrm{Ca}, \mathrm{Mg}$ e $\mathrm{Al} \rightarrow \mathrm{KCl}$ 1:10; $\rightarrow$ Água quente $\mathrm{S} \rightarrow$ Fosfato Monocálcico;

\subsection{Delineamento experimental e tratamentos}

O delineamento experimental utilizado foi de blocos ao acaso, com quatro repetições, cujos tratamentos foram distribuídos em um arranjo fatorial (3 x 5), constando de três doses de fósforo (utilizado como adubação corretiva) aplicados em área total $\left(0,100\right.$ e $200 \mathrm{~kg} \mathrm{ha}^{-1}$ de $\left.\mathrm{P}_{2} \mathrm{O}_{5}\right)$ e incorporados a $20 \mathrm{~cm}$ de profundidade, e cinco doses de fósforo $\left(0,45,90,135\right.$ e $180 \mathrm{~kg} \mathrm{ha}^{-1}$ de $\left.\mathrm{P}_{2} \mathrm{O}_{5}\right)$ aplicados anualmente no sulco de plantio, utilizando como fonte o Superfosfato Triplo (Figura 1). Cada unidade experimental possuía uma área total de $54 \mathrm{~m}^{2}$ (4,5 m x $\left.12 \mathrm{~m}\right)$, com dez linha de plantio. A área útil avaliada foi de $40 \mathrm{~m}^{2}$, com oito linhas centrais de plantio, utilizando uma bordadura de 0,45 m (distância entre linhas de plantio). 


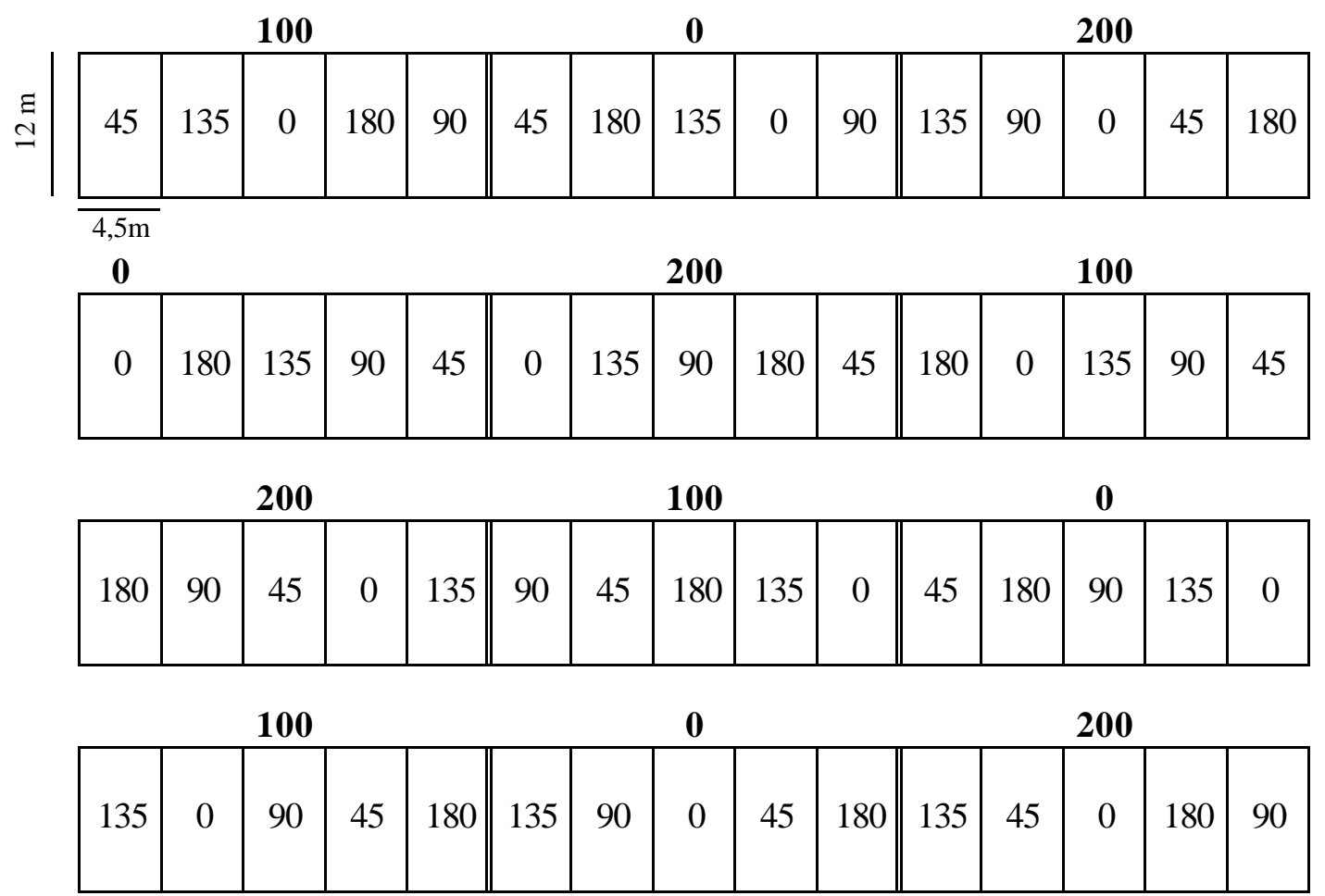

Números em negrito correspondem as doses de fosfatagem, números sem negritar correspondem as doses de fósforo aplicados no sulco de plantio.

Figura 1- Croqui do experimento.

\subsection{Instalação do experimento}

A área onde foi instalado o experimento foi mantida como campo nativo até 1986, quando foi instalada a cultura da soja com tecnologia de média a baixa por quatro anos. Em 1990 a área passou a ser utilizada com pastagem, cuja gramínea instalada foi a Brachiaria brizantha, (Braquiarão). Em 2000, a área apresentava aspectos de degradação, o que levou a hipótese de utilizar o sistema de plantio direto como forma de recuperação do solo. 


\subsubsection{Preparo do solo, adubação e plantio}

O experimento foi conduzido por dois anos agrícolas, 2000/2001 e 2001/2002.

O preparo inicial foi realizado pelo sistema convencional, em 19/09/2000, com aplicação de calcário e gesso agrícola, seguido de duas gradagens pesadas e subsolagem, complementando com duas gradagens normais.

Foram aplicados 3,0 $\mathrm{T} \mathrm{ha}^{-1}$ de calcário dolomítico, 0,8 $\mathrm{T} \mathrm{ha}^{-1}$ de gesso, $285 \mathrm{Kg}$ $\mathrm{ha}^{-1}$ de cloreto de potássio (150 Kg para correção e $135 \mathrm{Kg}$ para manutenção) e $6 \mathrm{Kg} \mathrm{ha}^{-1}$ de zinco e $3 \mathrm{Kg} \mathrm{ha}^{-1}$ de boro junto com a potassagem, em área total, de acordo com análise de solo (tabela 1). A aplicação de potássio, boro e zinco foi realizada uma semana após a calagem + gessagem (26/09/2000), procedendo a seguir, incorporação com grade niveladora.

A fosfatagem (adubação corretiva) utilizando-se 0, 100 e $200 \mathrm{~kg} \mathrm{ha}^{-1}$ de $\mathrm{P}_{2} \mathrm{O}_{5}$, como superfosfato triplo, em área total, foi feita um mês após a calagem + gessagem (20/10/2000), procedendo a incorporação com uma gradagem pesada $(0-25 \mathrm{~cm})$ e uma niveladora $(0-10 \mathrm{~cm})$.

Cerca de dez dias após a fosfatagem foi realizado o plantio da soja (29/10/2000), utilizado-se a cultivar CD 202, nas unidades experimentais e a cultivar BRS 133 nas ruas, semeando-se 22 sementes por metro linear, num espaçamento de 0,45 $\mathrm{m}$ entrelinhas. As sementes foram tratadas com fungicidas, micronutrientes $\mathrm{e}$ inoculante. No plantio foram aplicadas as doses de 0, 45, 90, 135 e $180 \mathrm{~kg}$ de $\mathrm{P}_{2} \mathrm{O}_{5} \mathrm{ha}^{-1}$ no sulco na forma de superfosfato triplo.

Os tratos culturais realizados durante o desenvolvimento do experimento seguiram as recomendações técnicas para a cultura.

Cerca de 120 dias após o plantio (27/02/2001) foi realizada a primeira colheita. Após a colheita, em abril de 2001, realizou-se o plantio da cultura de cobertura, aveia branca, cultivar FMS1, que foi dessecada quando começou o preenchimento dos grãos, com aplicação de glifosate.

O segundo plantio foi realizado em sistema de plantio direto sobre a palha formada pela a aveia branca. Foram aplicados gesso agrícola e cloreto de potássio em 
08/10/2001, à lanço sob a superfície, nas seguintes doses: $350 \mathrm{~kg} \mathrm{ha}^{-1}$ e $135 \mathrm{~kg} \mathrm{ha}^{-1}$, respectivamente. $\mathrm{O}$ plantio foi realizado em $01 / 11 / 01$, mantendo as mesmas cultivares nas unidades experimentais e nas ruas aplicando novamente as doses de $0,45,90,135 \mathrm{e}$ $180 \mathrm{~kg}$ de $\mathrm{P}_{2} \mathrm{O}_{5}$ ha $^{-1}$ no sulco na forma de superfosfato triplo. As sementes também foram tratadas com micronutrientes, fungicida e inoculante.

Os tratos culturais realizados durante o desenvolvimento do experimento no segundo cultivo seguiram as recomendações técnicas para a cultura.

Cerca de 120 dias após o plantio (03/03/2002) foi realizada a segunda colheita.

\subsection{Obtenção dos resultados}

\subsubsection{Amostragem do solo e de plantas}

\subsubsection{Solo}

A primeira amostragem de solo foi realizada entre os dias 05 e 07/05/2001. O procedimento consistiu em coletas de amostras apenas nas linhas de plantio, apenas nas entrelinhas e misturando linha e entrelinha na mesma proporção (1:1).

Como o espaçamento utilizado entrelinhas foi de $0,45 \mathrm{~m}$, as amostras das entrelinhas foram coletadas àcerca de $0,20 \mathrm{~m}$ da linha (região central).

Cada amostra de solo foi composta de oito sub-amostras, coletadas tanto nas linhas de plantios como nas entrelinhas, em cada unidade experimental. Para a amostragem tipo mistura (mistura de linha e entrelinha), foram coletadas quatro subamostras nas linhas e quatro sub-amostras nas entrelinhas, totalizando em oito subamostras, mesma quantidade quando os locais foram coletados em separado.

As amostras foram coletadas nas profundidade de 0-10, 10-20 e 0-20 cm, com um amostrador tipo sonda, de aço inox, com $0,50 \mathrm{~m}$ de comprimento por 0,05 de diâmetro. 
A segunda amostragem foi realizada entre os dias 14 e 16/05/2002. Foi realizado o mesmo procedimentos quanto aos locais, número de sub-amostras e profundidades amostradas, bem como o amostrador.

Neste segundo ano, adicionou-se mais um local de coleta, que consistiu na retirada de solo formando uma trincheira, começando de uma entrelinha (cerca de 0,20m da linha) até a outra entrelinha (também à cerca de $0,20 \mathrm{~m}$ da linha), ficando a linha de plantio centralizada na faixa de coleta. As profundidades de coleta foram as mesmas utilizadas no experimento. Foi utilizado para esta coleta o amostrador tipo vanga, coletando três subamostras por unidade experimental.

Após cada coleta, as amostras de solo foram secas em estufa à $45^{\circ} \mathrm{C}$, homogeneizadas e passadas por peneira com malha de $2 \mathrm{~mm}$.

\subsubsection{Planta}

A primeira coleta de folhas para análise foi realizada em 26/12/2000, utilizando folhas completamente desenvolvidas ( $3^{\mathrm{a}}$ folha à partir do ápice) no início de florescimento. Estas foram lavadas, colocadas em sacos de papel e levadas para secar em estufa com circulação forçada de ar, com temperatura variando de $65-70{ }^{\circ} \mathrm{C}$ até atingir peso constante.

A segunda coleta de folhas para análise foi realizada em 22/12/2001, utilizando dos mesmos procedimentos realizado na primeira coleta.

\subsubsection{Análises químicas do solo}

Foram avaliados o pH, matéria orgânica, potássio, cálcio, magnésio, enxofre, alumínio e acidez potencial de acordo com metodologias citadas por Raij et al. (2001). O fósforo foi determinado por dois métodos: o da resina trocadora de íons (Raij et al., 2001) e pelo Mehlich-1 (Embrapa, 1999). 


\subsubsection{1 $\mathrm{pH}$ em $\mathrm{CaCl}_{2}$ (acidez ativa)}

Medida da atividade de hidrogênio $\left(\mathrm{H}^{+}\right)$com eletrôdo combinado de vidro e

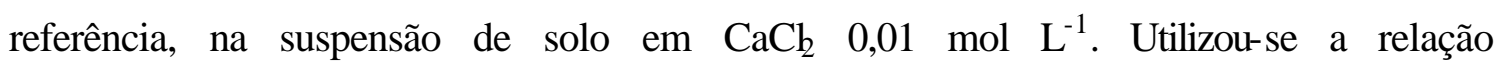
solo:solução de 1:2,5.

\subsubsection{Matéria orgânica}

Obtida de forma indireta, através de curva padrão, que relaciona as quantidades de matéria orgânica e a absorbância do extrato preparado com dicromato de sódio, pelo método colorimétrico. Utilizou-se a relação solo:solução de 1:10.

\subsubsection{Fósforo, potássio, cálcio e magnésio - resina}

Extração dos teores disponíveis de amostras de solo através da resina trocadora de íons e quantificação do fósforo por fotocolorimetria ou espectrofotômetria, do potássio por fotometria de chama e do cálcio e magnésio por espectrofotometria de absorção atômica. Utilizou-se a relação solo:água:resina de 1:10:1.

\subsubsection{Fósforo - Mehlich-1}

A solução extratora de Mehlich-1, também chamada de duplo-ácida ou de

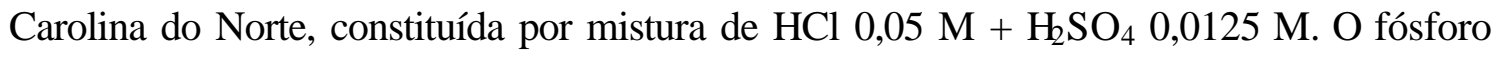
extraído foi determinado espectrofotometricamente a $660 \mathrm{~nm}$. Utilizou-se a relação solo:solução de 1:10.

\subsubsection{H + Al (acidez potencial)}

Pelo método SMP (Shoemaker, Mclean \& Pratt) onde o solo em contato com a solução tampão SMP provoca um decréscimo do valor original do pH da solução $(7,5)$. 
Sua leitura é feita em potenciômetro e correlacionada com valores obtidos pelo método CaHOAc 1N (estudo de correlação). Utilizou-se a relação solo: solução de 2:1.

\subsubsection{Alumínio}

A extração do alumínio trocável foi feita utilizado-se uma solução de $\mathrm{KCl} 1 \mathrm{~N}$, por ser um sal neutro, sendo a quantificação do alumínio realizada pelo emprego de solução de $\mathrm{NaOH}$ 0,025 mol L ${ }^{-1}$. Utilizou-se a relação solo:solução de 1:10.

\subsubsection{Análises químicas das plantas}

\subsubsection{Fósforo}

Colocou-se a amostra em saco de papel e levou-a à secar em estufa com circulação de ar forçada, com temperatura de $65^{\circ} \mathrm{C}$.

Para a moagem, utilizou-se um moinho de aço inoxidável com peneira de 1 $\mathrm{mm}$ de malha. Em seguida triturou-se a amostra e acondicionou-a em saquinho plástico devidamente identificado.

Para o preparo dos extratos utilizou-se a digestão ácida a quente, digestão sulfúrica e digestão nitrico-perclórica. Durante o processo de extração ocorre a retirada dos elementos de compostos orgânicos ou adsorvidos a esses compostos.

$\mathrm{O}$ fósforo é absorvido predominantemente na forma iônica de $\mathrm{H}_{2} \mathrm{PO}_{4}{ }^{-}$e ao contrário do nitrato e do sulfato, o fosfato não é reduzido na planta a um estado de oxidação diferente daquele em que foi absorvido. O método utilizado para determinar o Fósforo (Colorimetria do metavanadadato - fósforo total) baseia-se na formação de um composto amarelo do sistema vanadomolibdofosfórico em acidez de 0,2 a 1,6 N (Malavolta et. al., 1997).

A cor desenvolvida é quantificada em fotocolorímetro ou em espectrofotômetro utilizando-se um filtro de cor complementar à da amostra (filtro azul), medindo-se a porcentagem de transmissão (\%T) ou comumente de a absorbância (A). 


\subsection{Produção}

Foi determinada através de colheita manual de três linhas de plantio centrais, com espaçamento de $0,45 \mathrm{~m}$ por 4 metros de extensão, totalizando numa área de $5,4 \mathrm{~m}^{2}$ para cada unidade experimental. Após a colheita, os grãos passaram por processos de secagem, foram pesados e os dados transformados em $\mathrm{kg} \mathrm{ha}^{-1}$ (13\% de umidade).

\subsection{Análise estatística}

Os dados obtidos, referentes aos sistemas de amostragem, foram submetidos à análise de variância, para obtenção do teste $\mathrm{F}$, utilizando o teste de Tukey a $1 \%$ de probabilidade. Os dados referentes à aplicação de níveis de fosfatagem e de fósforo no sulco, foram submetidos à análise de variância (teste F) e a seguir, foi realizada análise de regressão, para verificar o efeito dos tratamentos aplicados com os locais e profundidades de amostragem avaliados.

Foi realizada análise de correlação entre os teores de fósforo no solo determinados por dois método extratores, resina trocadora de íons e Mehlich-1. Também foram correlacionados os teores de fósforo no solo como as produções obtidas e teores foliares. 


\section{RESULTADOS E DISCUSSÃO}

\subsection{Avaliação da disponibilidade de fósforo no sistema de plantio direto}

Neste item, são apresentados e discutidos os resultados da variação dos teores de fósforo no solo para os tratamentos utilizados, por dois anos agrícolas (2000/2001 e 2001/2002), em função de diferentes tipos de amostragens de solo e profundidades de amostragem, bem como, em diferentes extratores, com o objetivo de definir procedimentos de coleta de amostras que representem o estado de fertilidade do solo no sistema de plantio direto.

\subsubsection{Primeiro anos agrícola $(2000 / 2001)$}

\subsubsection{Efeito de local e profundidade de amostragem}

Os teores de fósforo no solo extraído pelo método da resina trocadora de íons apresentaram uma variação, entre os locais de amostragem, em torno de $75 \%$ nas profundidades de $010 \mathrm{~cm}$ e $0-20 \mathrm{~cm}$, e de $40 \%$ na profundidade de $10-20 \mathrm{~cm}$ (Tabela 7). O coeficiente de variação observado para os locais de amostragem, em cada profundidade, variou de 29,92 a 51,05\%, sendo considerados altos, valores próximos aos observados por Schlindwein (1999) utilizando o extrator Mehlich-1. Esta alta variação dos teores, provavelmente esteja relacionada a pontos de alta concentração de fósforo, principalmente nas camadas superficiais.

Dentre os locais de amostragem, em todas profundidades avaliadas, as amostras tipo mistura (linha e entrelinha na proporção de 1:1) e as amostras nas linhas 
de plantio apresentaram teores de fósforo significativamente $(p>0,01)$ superiores aos encontrados nas amostras das entrelinhas. Como a amostragem tipo mistura representa uma proporção de 1:1 das linhas e entrelinhas, era esperado que os teores obtidos representassem um valor próximo a média entre estes dois locais, contudo observou-se que foram muito próximos dos teores das linhas, indicando a influência dos teores das linhas (teores elevados) na mistura. Estes resultados são semelhantes aos obtidos por Salet et al. (1997).

Quanto a profundidade de amostragem, observou-se teores mais elevados na camada de 0-10 cm, para todos os locais de amostragem, este resultados era esperado, já que este nutriente se concentra em camadas mais superficiais $(0-5 \mathrm{~cm})$, conforme constatou Schlindwein \& Anghinoni (2000b). Na camada de 0-20 cm, os teores observados foram inferiores, porém próximos aos da camada de $0-10 \mathrm{~cm}$, o que mostra a influência, embora pequena, da mistura da camada superficial, com teores mais baixos deste nutrientes nas camadas mais inferiores, resultados estes também observados por Anghinoni \& Salet (1998). Este efeito de diluição dos teores de fósforo foi mais acentuado na amostragem nas entrelinhas, onde não ocorreu o efeito da adubação fosfatada em sulco.

Tabela 2. Teores de fósforo no solo, em $\mathrm{mg} \mathrm{dm}^{-3}$, extraídos pelo método da resina trocadora de íons, para os locais de amostragem avaliados e coeficiente de variação do solo, em diferentes profundidades para o primeiro ano agrícola.

\begin{tabular}{ccccc}
\hline \multirow{2}{*}{$\begin{array}{c}\text { Profundidade } \\
\text { de amostragem }\end{array}$} & \multicolumn{3}{c}{ Locais de amostragem } & \multirow{2}{*}{$\begin{array}{c}\text { Coeficiente de } \\
\text { variação }\end{array}$} \\
\cline { 2 - 3 }$(\mathrm{cm})$ & Linha (L) & Entrelinha (E) & Mistura (LxE) & $(\%)$ \\
$0-10$ & $83 \mathrm{~A}$ & $\mathrm{mg} \mathrm{dm}^{-3}$ & & 49,14 \\
$10-20$ & $25 \mathrm{~A}$ & $21 \mathrm{~B}$ & $24 \mathrm{~A}$ & 29,92 \\
$0-20$ & $66 \mathrm{~A}$ & $20 \mathrm{~B}$ & $62 \mathrm{~A}$ & 51,05 \\
\hline Obs.: Médias seguidas por letras iguais na linha não diferem entre si pelo teste de Tukey ao nível de \\
\multicolumn{2}{l}{ significância de 1\%. }
\end{tabular}


Os teores de fósforo extraídos do solo pelo método Mehlich-1 entre os locais de amostragem, apresentaram uma variação em torno de 74, 60 e $80 \%$ para as profundidades de 0-10, 10-20 e 0-20 cm, respectivamente (Tabela 3).

O coeficiente de variação observado para os locais de amostragem, em cada profundidade, variou de 42,47 a $80,25 \%$, sendo considerados altos e, superiores aos encontrados para o extrator resina, bem como aos observados por Schlindwein (1999).

Nas profundidades de 0-10 e 10-20 cm, as amostragens realizadas nas linhas de plantio e tipo mistura, apresentaram teores de fósforo significativamente superiores ( $>0,01)$ aos teores nas amostragens nas entrelinhas, comportamento semelhante ao observados com extrator resina. Na profundidade de 10-20 cm não houve diferença entre os locais amostrados.

Tabela 3 : Teores de fósforo no solo, em $\mathrm{mg} \mathrm{dm}^{-3}$, extraídos pelo método Mehlich-1, para os locais de amostragem avaliados e seu coeficiente de variação do solo em diferentes profundidades, para o primeiro ano agrícola.

\begin{tabular}{|c|c|c|c|c|}
\hline \multirow{2}{*}{$\begin{array}{l}\text { Profundidade } \\
\text { de amostragem }\end{array}$} & \multicolumn{3}{|c|}{ Locais de amostragem } & \multirow{2}{*}{$\begin{array}{l}\text { Coeficiente de } \\
\text { variação }\end{array}$} \\
\hline & Linha (L) & Entrelinha (E) & Mistura (LxE) & \\
\hline (cm) & & $\mathrm{mg} \mathrm{dm}^{-3}$ & & $(\%)$ \\
\hline $0-10$ & $24 \mathrm{~A}$ & $6 \mathrm{~B}$ & $25 \mathrm{~A}$ & 42,47 \\
\hline $10-20$ & $10 \mathrm{~A}$ & $4 \mathrm{~A}$ & $8 \mathrm{~A}$ & 80,25 \\
\hline $0-20$ & $25 \mathrm{~A}$ & $5 \mathrm{~B}$ & $28 \mathrm{~A}$ & 77,54 \\
\hline
\end{tabular}

\subsubsection{Efeito da fosfatagem e aplicação de fósforo em sulco}

As doses de fósforo aplicadas em fosfatagem não interferiram, significativamente, nos teores de fósforo no solo avaliados pelos dois extratores, nos 
diferentes locais de amostragem, o que se justifica pelo fato de que essas doses de fósforo foram aplicados homogeneamente em área total. No entanto, quando avaliou-se os efeitos das doses de fosfatagem aplicadas em cada profundidade de amostragem, os teores de fósforo no solo foram afetados significativamente ( $p>0,01)$, apresentando aumento linear com as doses de fosfatagem, para os dois extratores de fósforo (Figura 2).
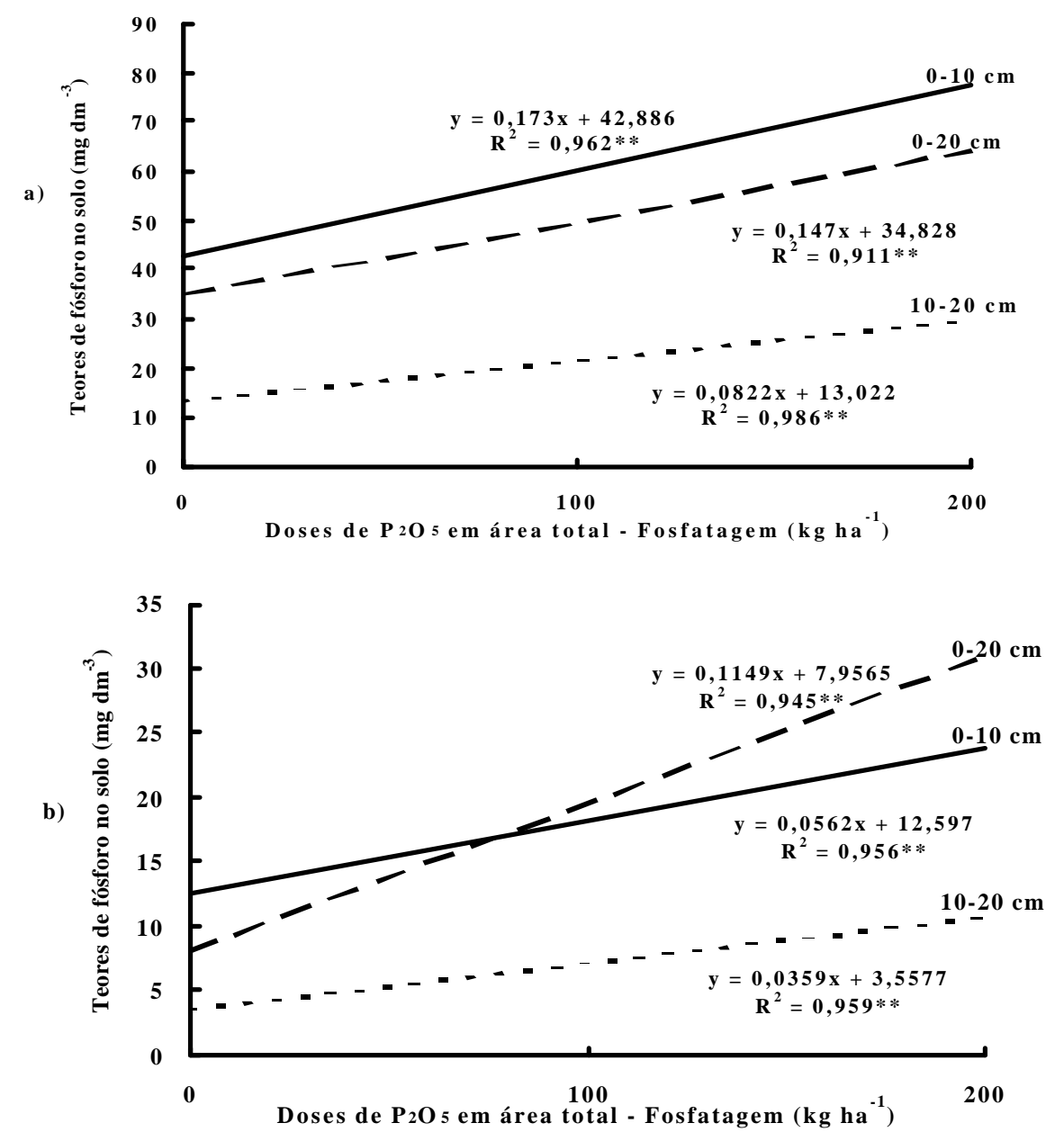

Figura 2 - Teores de fósforo no solo em função das doses de $\mathrm{P}_{2} \mathrm{O}_{5}$ em área total (fosfatagem) em três profundidades de amostragem, para o primeiro ano agrícola. a) Extraído pelo método da resina trocadora de íons; b) Extraído pelo método Mehlich-1. 
Como esperado, as maiores concentrações de fósforo no solo se encontram na camada de 010 cm (Figura 2a), sendo $34 \%$ maior que as concentrações na camada de $10-20 \mathrm{~cm}$. A amostragem na profundidade de $020 \mathrm{~cm}$, apresentou resultados inferiores, porém bem próximos aos observados na camada de $0-10 \mathrm{~cm}$, o que reafirma o fato de o fósforo se concentrar nas camadas superficiais, e à medida que se aprofunda seu efeito é diluído.

Para o extrator Mehlich-1 (Figura 2b), os resultados foram semelhantes aos obtidos para o extrator resina (Figura 2a), com exceção as camada de 0-20 cm, onde os teores de fósforo no solo foram superiores aos da camada de $010 \mathrm{~cm}$, principalmente nas doses mais elevadas de fosfatagem. Fato este não esperado, já que esta amostragem deveria apresentar teores entre os observados para as camadas de 0-10 cm e de 10-20 cm. Este resultado pode ser atribuído a elevada variação dos dados obtidos na camada de $0-20 \mathrm{~cm}$.

As doses de fósforo aplicadas no sulco de plantio afetaram significativamente ( $p>0,01)$ os teores de fósforo no solo, principalmente nas amostragens onde se incluí a camada superficial $(0-10$ e $0-20 \mathrm{~cm})$ (Figura 3). Os teores encontrados na profundidade de 10-20 cm não foram afetados significativamente pelas doses de fósforo aplicadas no sulco, quando se utilizou o extrator Mehlich-1 na extração do fósforo no solo (Figura 3b), mas ao mesmo tempo, foram afetados significativamente pelas doses de fósforo aplicadas no sulco para o extrator resina. Este resultado pode indicar que o fósforo presente nesta camada esteja ligado quimicamente ao ferro e ao alumínio, ligações estas pouco sensíveis à extratores ácidos, como o caso do Mehlich-1 (Vale et al., 1998). 

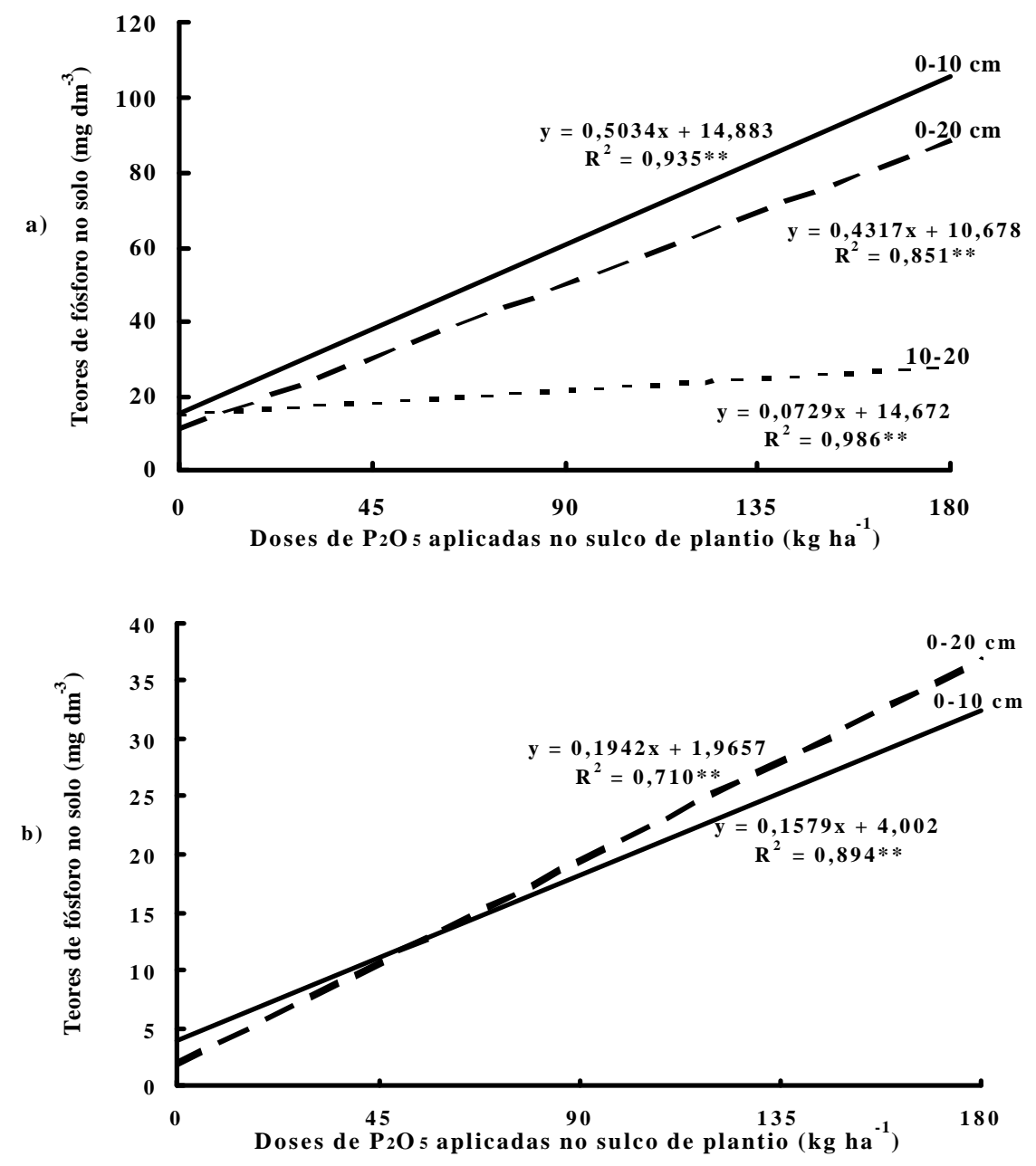

Figura 3 - Teores de fósforo no solo em função das doses de $\mathrm{P}_{2} \mathrm{O}_{5}$ aplicados no sulco de plantio em três profundidades de amostragem, para o primeiro ano agrícola. a) Extraído pelo método da resina trocadora de íons; b) Extraído pelo método Mehlich-1.

Quanto aos locais de amostragem, os teores de fósforo no solo, obtidos pelos extratores resina e Mehlich-1, aumentaram significativamente $(p>0,01)$ e de forma linear com as doses de fósforo aplicadas no sulco de plantio, tanto na profundidade $010 \mathrm{~cm}$ 
(Figura 4a e 5a), como na profundidade de 0-20 cm (Figura $4 \mathrm{~b}$ e 5b), tanto nas amostras coletadas nas linhas como nas amostras tipo mistura, enquanto que na camada de 10-20 cm não foram afetados significativamente.

a)

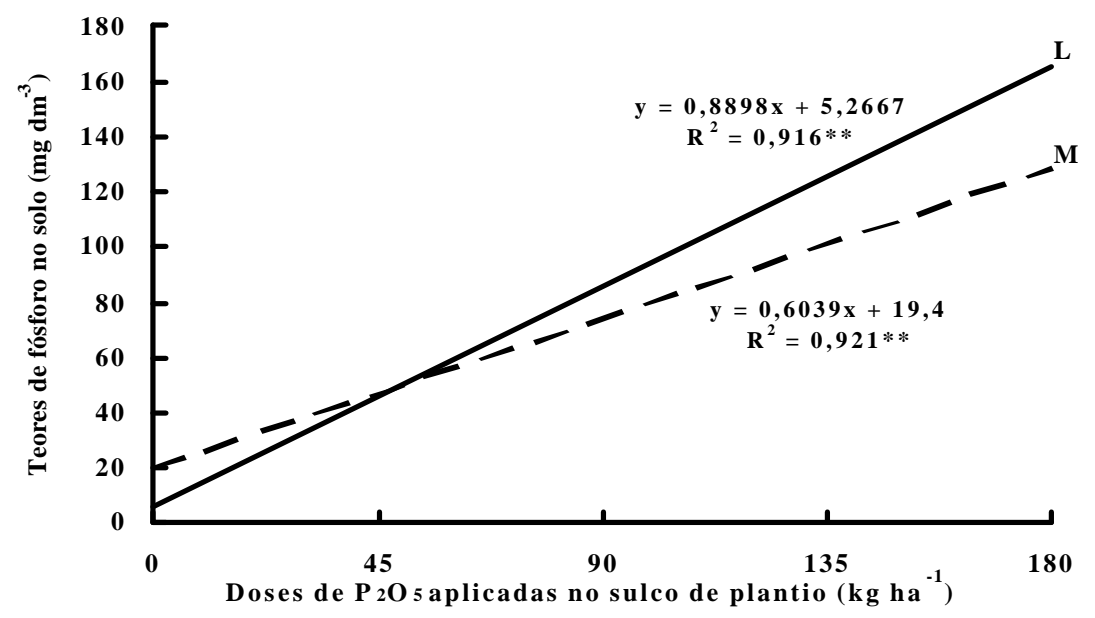

b)

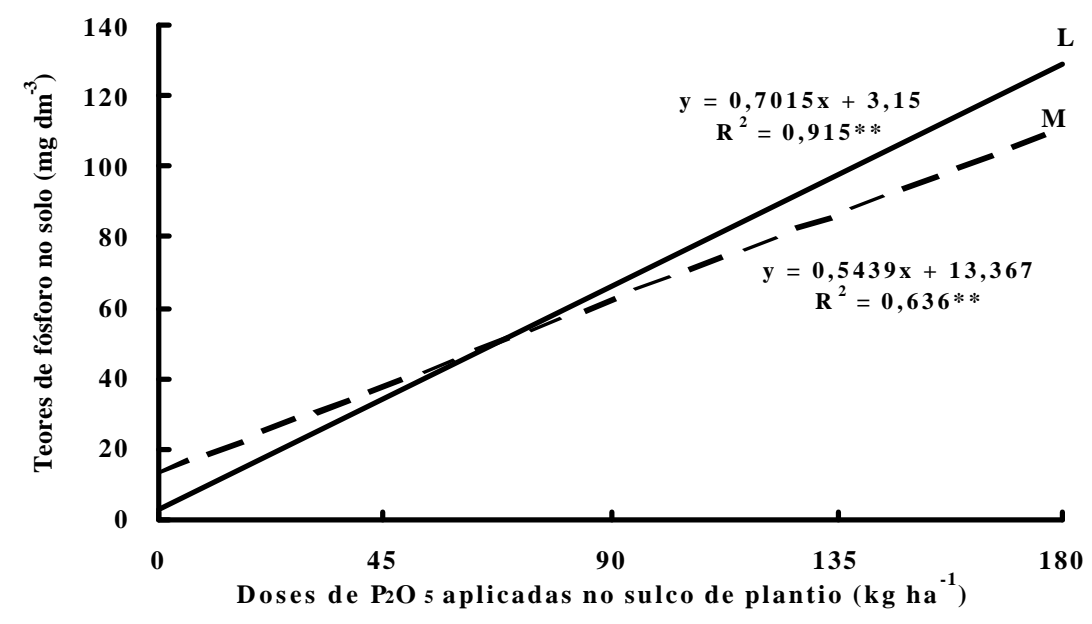

Figura 4 - Teores de fósforo no solo pelo extrator resina trocadora de íons em função das doses de $\mathrm{P}_{2} \mathrm{O}_{5}$ aplicados no sulco de plantio nas amostragens realizadas na linha de plantio (L) e tipo mistura (M), para o primeiro ano agrícola. a) profundidade de $0-10 \mathrm{~cm}$; b) profundidade de $0-20 \mathrm{~cm}$. 
Nas amostras coletadas nas entrelinhas, como era esperado, as doses de fósforo aplicadas no sulco de plantio não influenciaram significativamente os teores de fósforo no solo.

a)

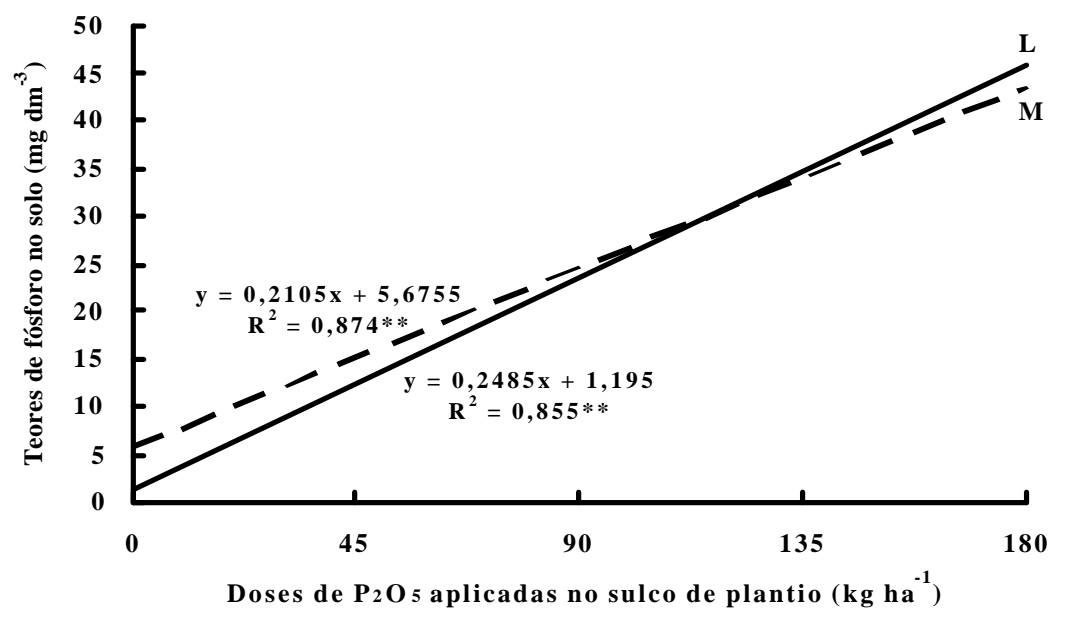

b)

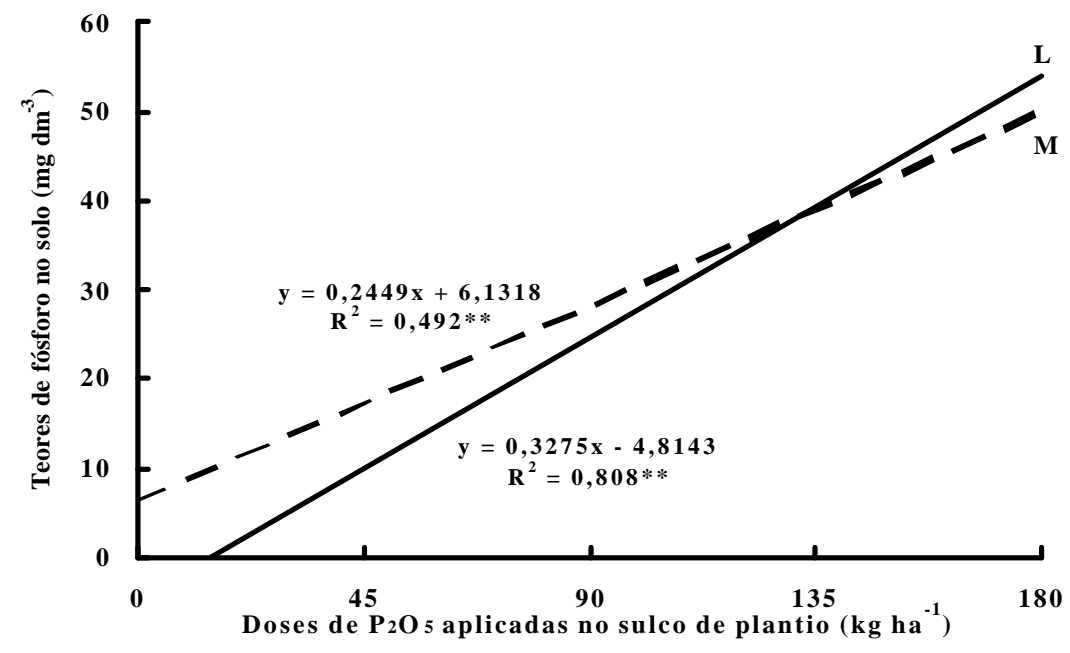

Figura 5 - Teores de fósforo no solo pelo extrator Mehlich-1 em função das doses de $\mathrm{P}_{2} \mathrm{O}_{5}$ aplicados no sulco de plantio nas amostragens realizadas na linha de plantio (L) e tipo mistura (M), para o primeiro ano agrícola. a) profundidade de $0-10 \mathrm{~cm}$; b) profundidade de $0-20 \mathrm{~cm}$. 
Observou-se que, tanto nas amostras coletadas na linha como nas amostras tipo mistura, os teores de fósforo no solo apresentaram comportamento semelhantes (Figuras 4 e 5), este fato pode indicar que, a proporção do solo utilizada na mistura não foi suficiente para diluir o efeito da localização do adubo.

Pelo extrator resina, nas duas profundidades (Figura 4), as amostragens realizadas nas linhas apresentaram teores de fósforo no solo maiores do que as amostragens tipo mistura já nas menores doses de fósforo aplicadas no sulco, enquanto que para o extrator Mehlich-1 (Figura 5), também nas duas profundidades, esta diferença foi sensível apenas em doses maiores de fósforo aplicados nu sulco.

Para o extrator resina, na profundidade de amostragem de $0-10 \mathrm{~cm}$, foi observado efeito significativo $(\mathrm{p}>0,05)$ para a interação entre local de amostragem, doses de fosfatagem e doses de fósforo aplicadas no sulco, cujos resultados são apresentados na tabela 4 .

Tabela 4. Funções para variação nos teores de fósforo no solo, pelo extrator resina, na profundidade de $010 \mathrm{~cm}$, em função das doses de fósforo aplicadas no sulco de plantio, para cada local de amostragem e doses de fosfatagem.

\begin{tabular}{lcccc}
\hline $\begin{array}{c}\text { Local de } \\
\text { amostragem }\end{array}$ & $\begin{array}{c}\text { Doses de } \mathrm{P}_{2} \mathrm{O}_{5}\left(\mathrm{~kg} \mathrm{ha}^{-1}\right) \\
\text { Fosfatagem }\end{array}$ & Função & $\mathrm{R}^{2}$ & Teste F \\
\hline \multirow{3}{*}{ Linha } & 0 & $\mathrm{Y}=0,569 \mathrm{X}+8,80$ & 0,976 & $1 \%$ \\
& 100 & $\mathrm{Y}=0,77 \mathrm{X}+18,45$ & 0,582 & $1 \%$ \\
& 200 & $\mathrm{Y}=1,33 \mathrm{X}-11,45$ & 0,744 & $1 \%$ \\
Entrelinha & 0 & & 0,435 & $\mathrm{~ns}$ \\
& 100 & & 0,567 & $\mathrm{~ns}$ \\
& 200 & $\mathrm{Y}=0,459 \mathrm{X}+21,9$ & 0,221 & $5 \%$ \\
Mistura & 0 & & 0,979 & $\mathrm{~ns}$ \\
& 100 & $\mathrm{Y}=0,248 \mathrm{X}+1,195$ & 0,855 & $1 \%$ \\
\hline
\end{tabular}




\subsubsection{Correlação entre o fósforo extraído do solo pelo método da resina trocadora de íons e o método Mehlich-1.}

Utilizando as amostras de todas as profundidades, a relação entre os extratores resina e Mehlich-1 apresentou coeficiente de correlação de 0,82 (Figura 6a). Quando ao ajustes foram estratificados pelas profundidades amostradas, o melhor ajuste foi obtido na camada de $010 \mathrm{~cm}(\mathrm{r}=0,93)$ e o menor ajuste na camada de $10-20 \mathrm{~cm}(\mathrm{r}=0,68)$. Estes valores de ajuste obtidos foram superiores aos de Brasil \& Muraoka (1997), que encontraram coeficientes de correlação de 0,496 e 0,529, para amostras coletadas antes da semeadura do caupi e do arroz, respectivamente, em cinco solos do Estado do Pará.

O menor ajuste na camada de $10-20 \mathrm{~cm}$ justifica-se pelo fato de que o extrator Mehlich-1 não foi sensível o suficiente para avaliar o efeito de doses de fósforo aplicadas no sulco, enquanto que o extrator resina foi sensível as doses utilizadas.

Observa-se que quando se utilizou todos os dados amostrados, os teores obtidos pelo extrator Mehlich-1 representaram 34\% dos teores obtidos pelo extrator resina. Para as camadas de 0-10, 10-20 e 0-20 cm, os teores obtidos pelo extrator Mehlich-1 representaram 30, 33 e 39 dos teores obtidos pelo extrator resina, respectivamente. Os maiores teores observados para o extrator resina podem estar relacionados ao fato de que, como o solo foi adubado com fósforo, tem-se que a reserva de fósforo lábil encontre-se em grande parte na forma de fosfato de alumínio (Raij, 1978), o que restringiu a extração pelo extrator Mehlich-1, devido ao seu caráter ácido. 

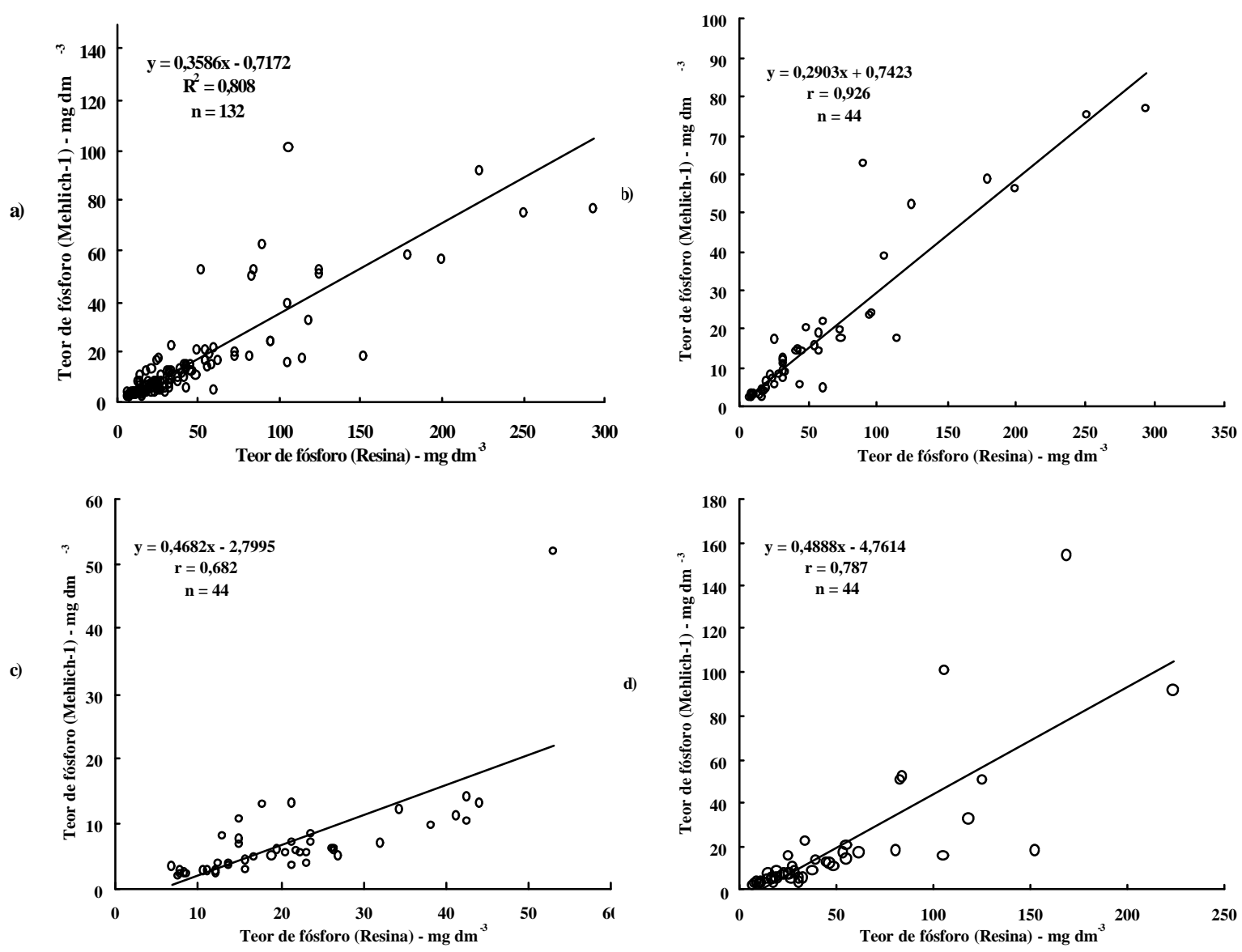

Figura 6 - Correlação entre os teores de fósforo extraídos pelo método resina e Mehlich-1, para o primeiro ano agrícola. a) teores gerais; b) teores na profundidade de $010 \mathrm{~cm}$; c) teores na profundidade de $10-20 \mathrm{~cm}$; d) teores na profundidade de $0-20 \mathrm{~cm}$

\subsubsection{Efeito da fosfatagem e aplicação de fósforo em sulco na produção}

A produção da soja aumentou significativamente $(p>0,01)$ e de forma linear com o aumento de doses de fósforo aplicadas no sulco de plantio (Figura 7). Para as doses de fosfatagem aplicadas, houve efeito significativo na produção, contudo ocorreu 
interação significativa com o fósforo aplicado no sulco somente para as doses de 0 e 100 $\mathrm{kg} \mathrm{ha}^{-1}$. Observa-se que a produção de soja passou de $1900 \mathrm{~kg} \mathrm{ha}^{-1}$, na ausência de aplicação de fósforo, para $4116 \mathrm{~kg} \mathrm{ha}^{-1}$, quando se aplicou $100 \mathrm{~kg} \mathrm{ha}^{-1}$ de fósforo na fosfatagem e $180 \mathrm{~kg} \mathrm{ha}^{-1}$ no sulco de plantio, o que representa um aumento de $117 \%$.

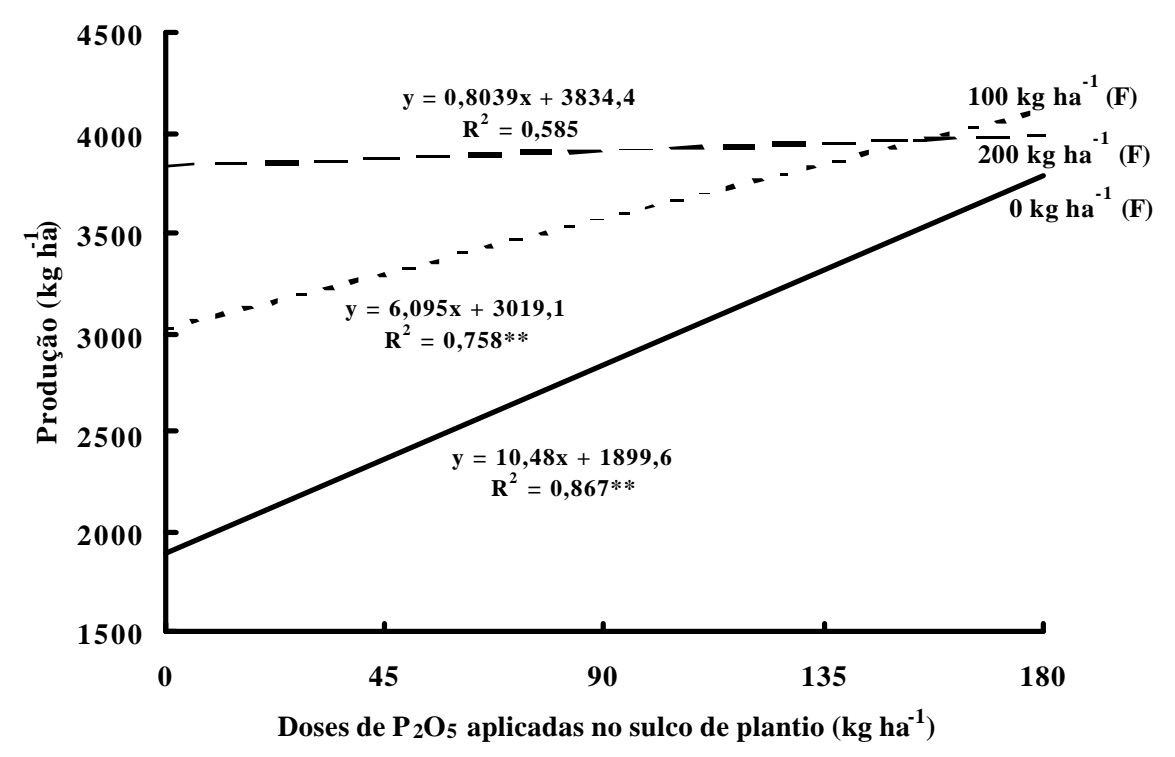

Figura 7 - Produção de soja, em $\mathrm{kg} \mathrm{ha}^{-1}$, em função das doses de $\mathrm{P}_{2} \mathrm{O}_{5}$ aplicadas no sulco de plantio e das doses de $\mathrm{P}_{2} \mathrm{O}_{5}$ em fosfatagem $(\mathrm{F})$, para o primeiro ano agrícola.

Quando se relaciona as produções obtidas com os teores de fósforo determinados no solo pelos extratores resina e Mehlich-1, nos diferentes locais de amostragem do solo e nas profundidades de coleta (Tabela 5), as melhores correlações foram obtidas quando se realizou amostragem nas linhas de plantio e nas profundidades de 0-10 e 0-20 cm, para os dois métodos de extração de fósforo.

Para a amostragem tipo mistura, os ajustes obtidos foram inferiores, porém próximos aos da linha, contudo observou-se que as melhores correlações foram obtidas nas profundidades de 0-10 e 10-20 cm, em ambos extratores. 
O melhor ajuste entre produção e os teores de fósforo no solo para o extrator resina foi obtido na amostragem feita nas linhas na profundidade de $020 \mathrm{~cm}$, enquanto que para o extrator Mehlich-1 o melhor ajuste foi obtido na amostragem das linhas e na profundidade de $010 \mathrm{~cm}$. Tanto na amostragem nas linhas como para a amostragem tipo mistura, os maiores coeficientes de correlação obtidos, para a relação entre os teores de fósforo no solo e a produção, foram observados quando se utilizou o extrator resina. Resultado semelhante também é relatado por Raij et al. (1986), para a cultura do algodão.

Tabela 5. Funções para variação na produção de soja, em função dos teores de fósforo no solo, determinada por dois extratores, para cada local de amostragem e profundidade avaliados, no primeiro ano agrícola.

\begin{tabular}{lccc}
\hline Local & $\begin{array}{c}\text { Profundidade } \\
(\mathrm{cm})\end{array}$ & Resina & $\mathrm{r}$ \\
\hline \multirow{4}{*}{ Entrelinha } & $0-10$ & $\mathrm{Y}=-0,6192 \mathrm{X}^{2}+47,097 \mathrm{X}+2772,5$ & 0,277 \\
& $10-20$ & $\mathrm{Y}=0,7988 \mathrm{X}^{2}-3,5848 \mathrm{X}+3288$ & 0,202 \\
Linha & $0-20$ & $\mathrm{Y}=-1,0294 \mathrm{X}^{2}+76,821 \mathrm{X}+2422,7$ & 0,396 \\
& $0-10$ & $\mathrm{Y}=-0,0543 \mathrm{X}^{2}+20,497 \mathrm{X}+2380,4$ & 0,766 \\
& $10-20$ & $\mathrm{Y}=-1,0304 \mathrm{X}^{2}+88,725 \mathrm{X}+2034,5$ & 0,566 \\
Mistura & $0-20$ & $\mathrm{Y}=-0,1855 \mathrm{X}^{2}+41,005 \mathrm{X}+1992,6$ & 0,852 \\
& $0-10$ & $\mathrm{Y}=-0,0701 \mathrm{X}^{2}+23,151 \mathrm{X}+2382$ & 0,685 \\
& $10-20$ & $\mathrm{Y}=-2,174 \mathrm{X}^{2}+154,88 \mathrm{X}+1217,6$ & 0,702 \\
Entrelinha & $0-20$ & $\mathrm{Y}=-0,0644 \mathrm{X}^{2}+19,858 \mathrm{X}+2628,6$ & 0,578 \\
& $0-10$ & $\mathrm{Y}=7,2939 \mathrm{X}^{2}-65,783 \mathrm{X}+3451,9$ & 0,311 \\
& $10-20$ & $\mathrm{Y}=-64,901 \mathrm{X}^{2}+630,14 \mathrm{X}+2137,6$ & 0,286 \\
Linha & $0-20$ & $\mathrm{Y}=-12,767 \mathrm{X}^{2}+256,38 \mathrm{X}+2498,5$ & 0,360 \\
& $0-10$ & $\mathrm{Y}=-0,5719 \mathrm{X}^{2}+57,329 \mathrm{X}+2672,7$ & 0,636 \\
& $10-20$ & $\mathrm{Y}=-1,9945 \mathrm{X}^{2}+128,55 \mathrm{X}+2648,9$ & 0,521 \\
Mistura & $0-20$ & $\mathrm{Y}=-0,2405 \mathrm{X}^{2}+44,047 \mathrm{X}+2821,9$ & 0,619 \\
& $0-10$ & $\mathrm{Y}=-0,4823 \mathrm{X}^{2}+51,354 \mathrm{X}+2687,6$ & 0,528 \\
& $10-20$ & $\mathrm{Y}=-8,6587 \mathrm{X}^{2}+215,79 \mathrm{X}+2412,7$ & 0,454 \\
& $0-20$ & $\mathrm{Y}=-0,0945 \mathrm{X}^{2}+16,778 \mathrm{X}+3127,5$ & 0,351 \\
\hline
\end{tabular}




\subsubsection{Efeito da fosfatagem e aplicação de fósforo em sulco sobre teor de fósforo na planta}

Os teores de fósforo nas folhas de soja aumentaram significativamente ( $>0,01)$ e de forma linear com o aumento das doses de fósforo aplicadas no sulco de plantio (Figura 8). Para as doses de fosfatagem aplicadas, houve efeito significativo nos teores foliares, contudo não ocorreu interação significativa com o fósforo aplicado no sulco. Observa-se que os teores de fósforo foliar passaram de 1,62 $\mathrm{g} \mathrm{kg}^{-1}$, na ausência de aplicação de fósforo, para $1,98 \mathrm{~g} \mathrm{~kg}^{-1}$, quando se aplicou $180 \mathrm{~kg} \mathrm{ha}^{-1}$ no sulco de plantio, o que representa um aumento de $22 \%$, contudo, ainda se situam abaixo dos teores considerados adequados para a cultura (Malavolta et al., 1989).

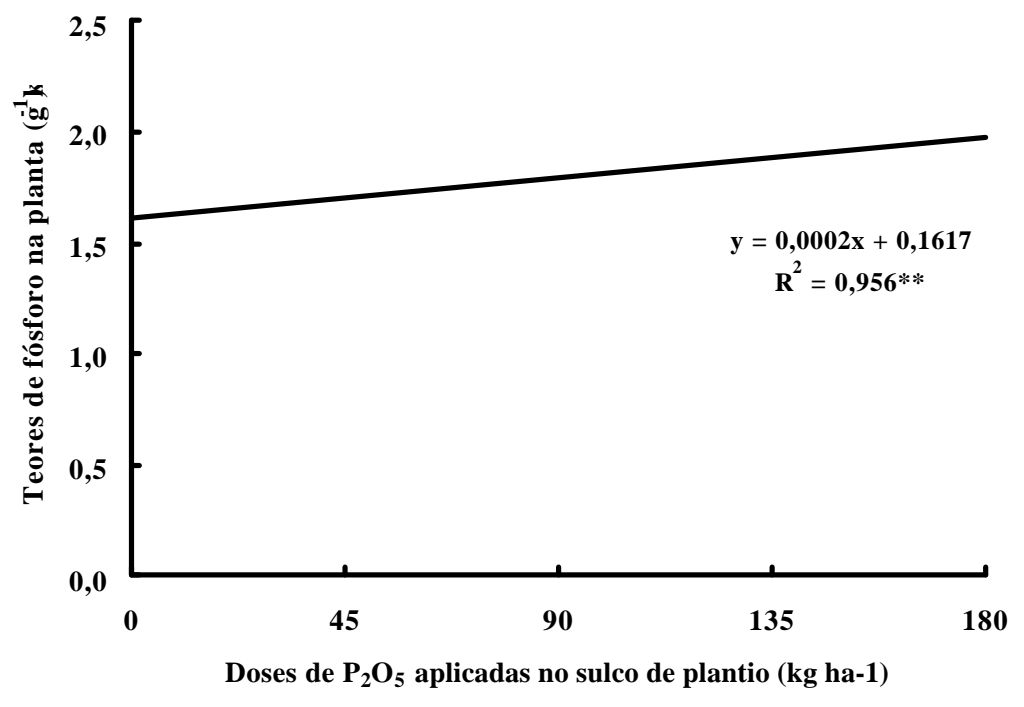

Figura 8 - Teores de fósforo na planta, em $\mathrm{g} \mathrm{kg}^{-1}$, em função das doses de $\mathrm{P}_{2} \mathrm{O}_{5}$ aplicadas no sulco de plantio e das doses de $\mathrm{P}_{2} \mathrm{O}_{5}$ em fosfatagem (F), para o primeiro ano agrícola.

Quando se correlacionou os teores de fósforo na planta com os teores de fósforo determinados no solo pelos extratores resina e Mehlich-1, nos diferentes locais 
de amostragem do solo e profundidade de coleta (Tabela 6), observa-se que as melhores correlações foram obtidas quando se realizou amostragem na linha de plantio e nas profundidades de 0-10 e 0-20 cm, para os dois métodos de extração de fósforo, concordando com os resultados obtidos para a produção. Estes resultados indicam que o aumento da produção de grãos de soja foi dependente do aumento nos teores de fósforo na planta. Do mesmo modo que para a relação entre teores de fósforo no solo e produção, o melhor ajuste entre os teores de fósforo no solo e os teores de fósforo na planta foi obtido no extrator resina, resultado semelhante ao obtido por Grande et al. (1986).

Tabela 6. Funções para variação no teor de fósforo na folha, em função dos teores de fósforo no solo, determinada por dois extratores, para cada local de amostragem e profundidade avaliados, no primeiro ano agrícola.

\begin{tabular}{|c|c|c|c|}
\hline Local & $\begin{array}{l}\text { Profundidade } \\
(\mathrm{cm})\end{array}$ & Função & $\mathrm{r}$ \\
\hline \multicolumn{4}{|c|}{ Resina } \\
\hline \multirow{4}{*}{ Entrelinha } & $0-10$ & $Y=-0,0002 X^{2}+0,0131 X+1,6147$ & 0,205 \\
\hline & $10-20$ & $Y=0,0012 X^{2}-0,032 X+1,9668$ & 0,228 \\
\hline & $0-20$ & $Y=0,0002 X^{2}-0,0042 X+1,7632$ & 0,379 \\
\hline & $0-10$ & $Y=-0,00002 X^{2}+0,0071 X+1,4216$ & 0,811 \\
\hline \multirow[t]{3}{*}{ Linha } & $10-20$ & $Y=-0,0001 X^{2}+0,0175 X+1,4762$ & 0,483 \\
\hline & $0-20$ & $Y=-0,00004 X^{2}+0,011 X+1,3562$ & 0,877 \\
\hline & $0-10$ & $Y=-0,00002 X^{2}+0,0071 X+1,4535$ & 0,690 \\
\hline \multirow[t]{3}{*}{ Mistura } & $10-20$ & $Y=-0,0003 X^{2}+0,0296 X+1,2784$ & 0,700 \\
\hline & $0-20$ & $\begin{array}{l}Y=-0,00002 X^{2}+0,0063 X+1,5224 \\
\text { Mehlich } 1\end{array}$ & 0,616 \\
\hline & $0-10$ & $Y=0,0028 X^{2}-0,0231 X+1,7853$ & 0,382 \\
\hline \multirow[t]{3}{*}{ Entrelinha } & $10-20$ & $Y=-0,0085 X^{2}+0,0935 X+1,5783$ & 0,164 \\
\hline & $0-20$ & $Y=0,0015 X^{2}+0,0108 X+1,6789$ & 0,360 \\
\hline & $0-10$ & $Y=-0,0002 X^{2}+0,019 X+1,5291$ & 0,674 \\
\hline \multirow[t]{3}{*}{ Linha } & $10-20$ & $Y=-0,0007 X^{2}+0,0486 X+1,4906$ & 0,610 \\
\hline & $0-20$ & $Y=-0,00009 X^{2}+0,0176 X+1,543$ & 0,753 \\
\hline & $0-10$ & $Y=-0,00006 X^{2}+0,0114 X+1,5799$ & 0,637 \\
\hline \multirow[t]{2}{*}{ Mistura } & $10-20$ & $Y=-0,0021 X^{2}+0,0637 X+1,4613$ & 0,495 \\
\hline & $0-20$ & $Y=0,00007 X^{2}-0,0032 X+1,7646$ & 0,552 \\
\hline
\end{tabular}




\subsubsection{Segundo ano agrícola (2001/2002)}

\subsubsection{Efeito de local e profundidade de amostragem}

Os teores de fósforo no solo extraído pelo método da resina trocadora de íons apresentaram uma variação, entre os locais de amostragem, em torno de $70 \%$ nas profundidades de $0-10 \mathrm{~cm}$ e $0-20 \mathrm{~cm}$, e de $30 \%$ na profundidade de $10-20 \mathrm{~cm}$ (Tabela 7). O coeficiente de variação observado para os locais de amostragem, na profundidade de 0-10 cm, apresentou-se maior do observado no primeiro ano agrícola e, consequentemente, maior que o observado por Schlindwein (1999), com o extrator Mehlich-1.

Tabela 7. Teores de fósforo no solo, em $\mathrm{mg} \mathrm{dm}^{-3}$, extraídos pelo método da resina trocadora de íons, para os locais de amostragem avaliados e seu coeficiente de variação do solo, em diferentes profundidades para o segundo ano agrícola.

\begin{tabular}{|c|c|c|c|c|c|}
\hline \multirow{2}{*}{$\begin{array}{l}\text { Profundidade } \\
\text { de } \\
\text { amostragem }\end{array}$} & \multicolumn{4}{|c|}{ Locais de amostragem } & \multirow{2}{*}{$\begin{array}{l}\text { Coeficiente } \\
\text { de variação }\end{array}$} \\
\hline & Linha $(\mathrm{L})$ & Entrelinha $(\mathrm{E})$ & Mistura (LxE) & Trincheira(T) & \\
\hline$(\mathrm{cm})$ & \multicolumn{4}{|c|}{$\mathrm{mg} \mathrm{dm}^{-3}$} & $(\%)$ \\
\hline $0-10$ & $51 \mathrm{~A}$ & $18 \mathrm{~B}$ & $46 \mathrm{~A}$ & $26 \mathrm{~B}$ & 58,937 \\
\hline $10-20$ & $13 \mathrm{~A}$ & $9 \mathrm{~B}$ & $12 \mathrm{AB}$ & $12 \mathrm{AB}$ & 28,388 \\
\hline $0-20$ & $34 \mathrm{~A}$ & $10 \mathrm{~B}$ & $29 \mathrm{~A}$ & $17 \mathrm{~B}$ & 37,334 \\
\hline
\end{tabular}

Obs.: Médias seguidas por letras iguais na linha não diferem entre si pelo teste de Tukey ao nível de significância de $1 \%$.

Este resultado confirma a hipótese, já abordada na discussão dos resultados do primeiro ano de cultivo, de que esta alta variação esteja relacionada à pontos de alta concentração de fósforo, principalmente nesta camada superficial $(0-10 \mathrm{~cm})$. Nesta 
camada, além do efeito residual das doses aplicadas no primeiro cultivo, houve reaplicação no segundo cultivo.

Nas outras profundidades avaliadas $(0-20$ e 10-20 cm) houve diminuição no coeficiente de variação em relação ao primeiro ano de cultivo, que pode ser atribuída à uma diluição do efeito das doses de fósforo aplicadas na fosfatagem ou no sulco no primeiro ano, como também a uma maior fixação do fósforo, se considerarmos a profundidade de 0-20 cm. Considerando a profundidade de $10-20 \mathrm{~cm}$, este menor coeficiente de variação pode ser atribuído à uma diminuição do efeito das doses em fosfatagem aplicadas na instalação do experimento, que foi incorporada até $20 \mathrm{~cm}$ de profundidade.

Entre os locais de amostragem, nas profundidades de 0-10 e 0-20 cm, as amostragens realizadas nas linhas e tipo mistura, apresentaram teores significativamente ( $>>0,01)$ maiores do que as amostragens realizadas nas entrelinhas e em trincheira. $\mathrm{Na}$ profundidade de 10-20 cm, as amostragens realizadas nas linhas não diferiram significativamente das amostragens tipo mistura e em trincheira, que apresentaram teores semelhantes, diferindo apenas das amostragens coletadas nas entrelinhas.

Em relação a profundidade, em todos locais de amostragem avaliados, os teores foram maiores na camada de 0-10 cm e menores na camada de 10-20 cm, tendência esperada e já observada no primeiro ano agrícola, que pode ser atribuída à adubação na linha de plantio. Na camada de $020 \mathrm{~cm}$, observa-se diluição do efeito da adubação.

Quando os teores de f́sforo no solo foi extraído pelo método Mehlich-1, nas profundidades de 0-10 e 0-20 cm, houve variação de até $90 \%$ nos teores encontrados nos diferentes locais de amostragem avaliados, e de até $60 \%$ na profundidade de $10-20 \mathrm{~cm}$ (Tabela 8).

O coeficiente de variação observado para os locais de amostragem, em cada profundidade, apresentaram valores superiores aos observados no primeiro ano agrícola, bem como aos encontrados para o extrator resina, nos dois anos agrícolas. Apenas para a profundidade de 10-20 cm houve diminuição no coeficiente de variação, porém ainda considerado, estatisticamente, alto. 
Quanto aos locais de amostragem, as linhas diferiram significativamente ( $>0,01)$ dos demais locais de amostragem avaliados, nas profundidades de 0-10 e 0-20 $\mathrm{cm}$. Na profundidade de 10-20 cm, os resultados obtidos foram semelhantes aos do extrator resina, nesta mesma profundidade.

Tabela 8. Teores de fósforo no solo, em $\mathrm{mg} \mathrm{dm}^{-3}$, extraídos pelo método da Mehlich-1, para os locais de amostragem avaliados e seu coeficiente de variação do solo, em diferentes profundidades para o segundo ano agrícola.

\begin{tabular}{|c|c|c|c|c|c|}
\hline \multirow{2}{*}{$\begin{array}{l}\text { Profundidade } \\
\text { de } \\
\text { amostragem }\end{array}$} & \multicolumn{4}{|c|}{ Locais de amostragem } & \multirow{2}{*}{$\begin{array}{l}\text { Coeficiente } \\
\text { de variação }\end{array}$} \\
\hline & Linha (L) & Entrelinha (E) & Mistura (LxE) & Trincheira(T) & \\
\hline$(\mathrm{cm})$ & \multicolumn{4}{|c|}{$\mathrm{mg} \mathrm{dm} \mathrm{dm}^{-3}$} & $(\%)$ \\
\hline $0-10$ & $27 \mathrm{~A}$ & $3 \mathrm{~B}$ & $13 \mathrm{~B}$ & $5 \mathrm{~B}$ & 84,737 \\
\hline $10-20$ & $3 \mathrm{~A}$ & $1 \mathrm{~B}$ & $2 \mathrm{AB}$ & $2 \mathrm{AB}$ & 31,453 \\
\hline $0-20$ & $14 \mathrm{~A}$ & $2 \mathrm{~B}$ & $3 \mathrm{~B}$ & $6 \mathrm{~B}$ & 77,163 \\
\hline
\end{tabular}

\subsubsection{Efeito da fosfatagem e aplicação de fósforo em sulco}

As doses de fósforo aplicadas na fosfatagem, como já foi observado no primeiro ano agrícola, não interferiram significativamente, nos teores de fósforo no solo, para os locais de amostragem avaliados. Quando se avaliou os efeitos das doses de fosfatagem aplicadas, em cada profundidade de amostragem avaliada, os teores de fósforo extraído pelo método da resina (Figura 9a) foram afetados significativamente ( $>0,01)$, apresentando aumento linear com as doses utilizadas, similar ao observado no primeiro ano agrícola. 


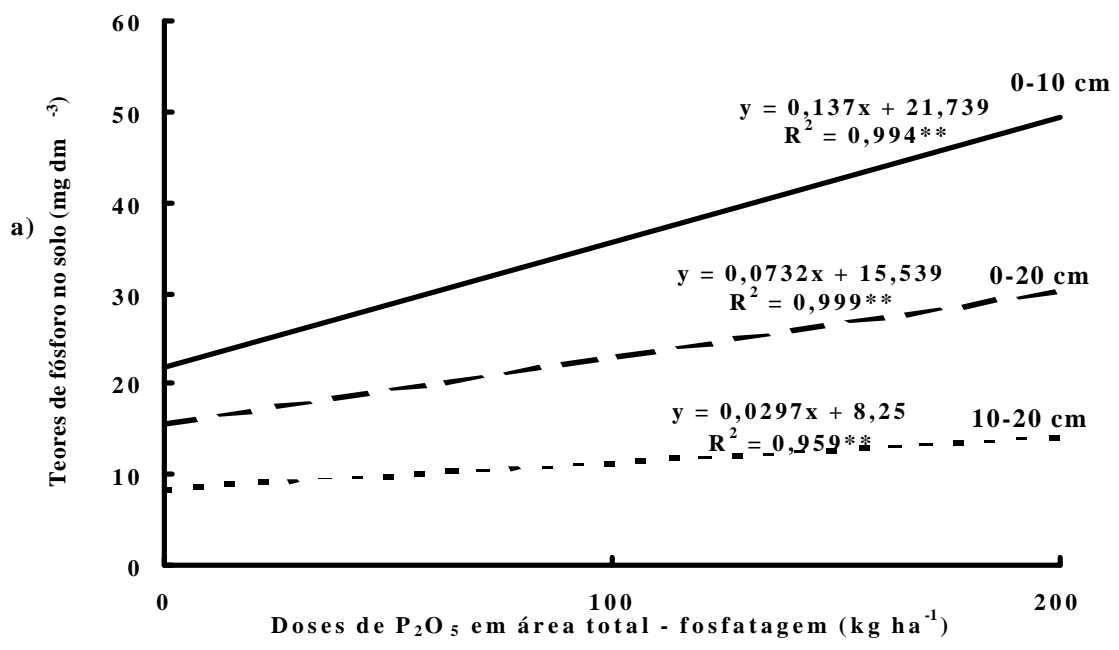

b)

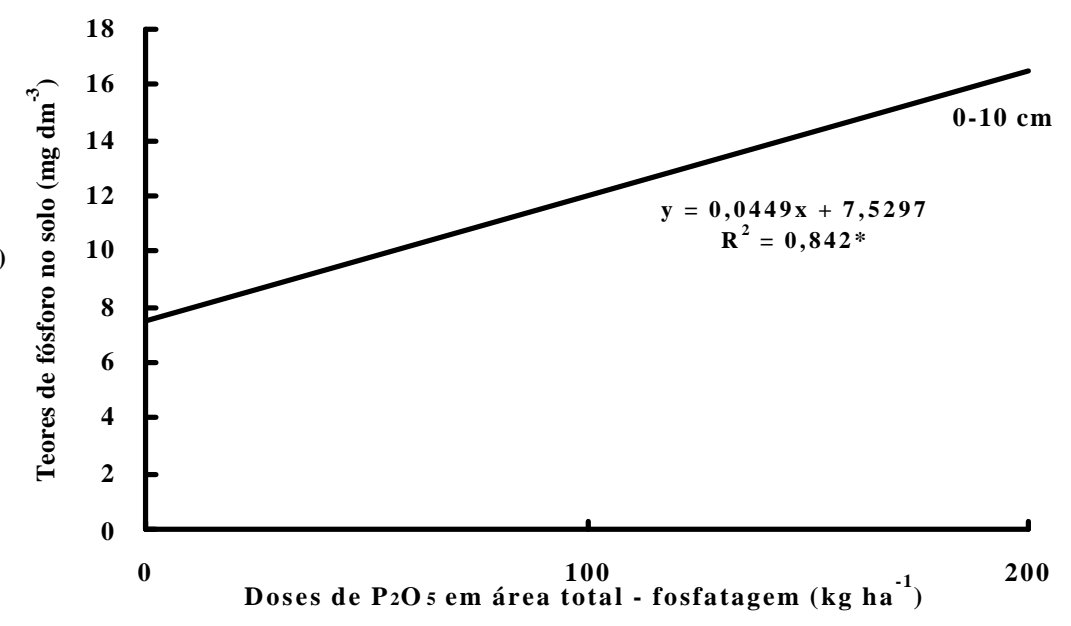

Figura 9 - Teores de fósforo no solo em função das doses de fosfatagem em três profundidades de amostragem (segundo ano agrícola). a) Extraído pelo método da resina trocadora de íons; b) Extraído pelo método Mehlich-1.

Para o extrator Mehlich-1 (Figura 9b), as doses de fosfatagem interferiram significativamente $(p>0,01)$ nos teores de fósforo no solo, apenas na profundidade de $\theta$ $10 \mathrm{~cm}$, camada esta que, segundo Schlindwein \& Anghinoni (2000b), o fósforo concentra-se em maior proporção. 
As doses de fósforo aplicadas no sulco de plantio afetaram significativamente ( $>>0,01)$ os teores de fósforo no solo, nas três profundidades estudadas (Figura 10).
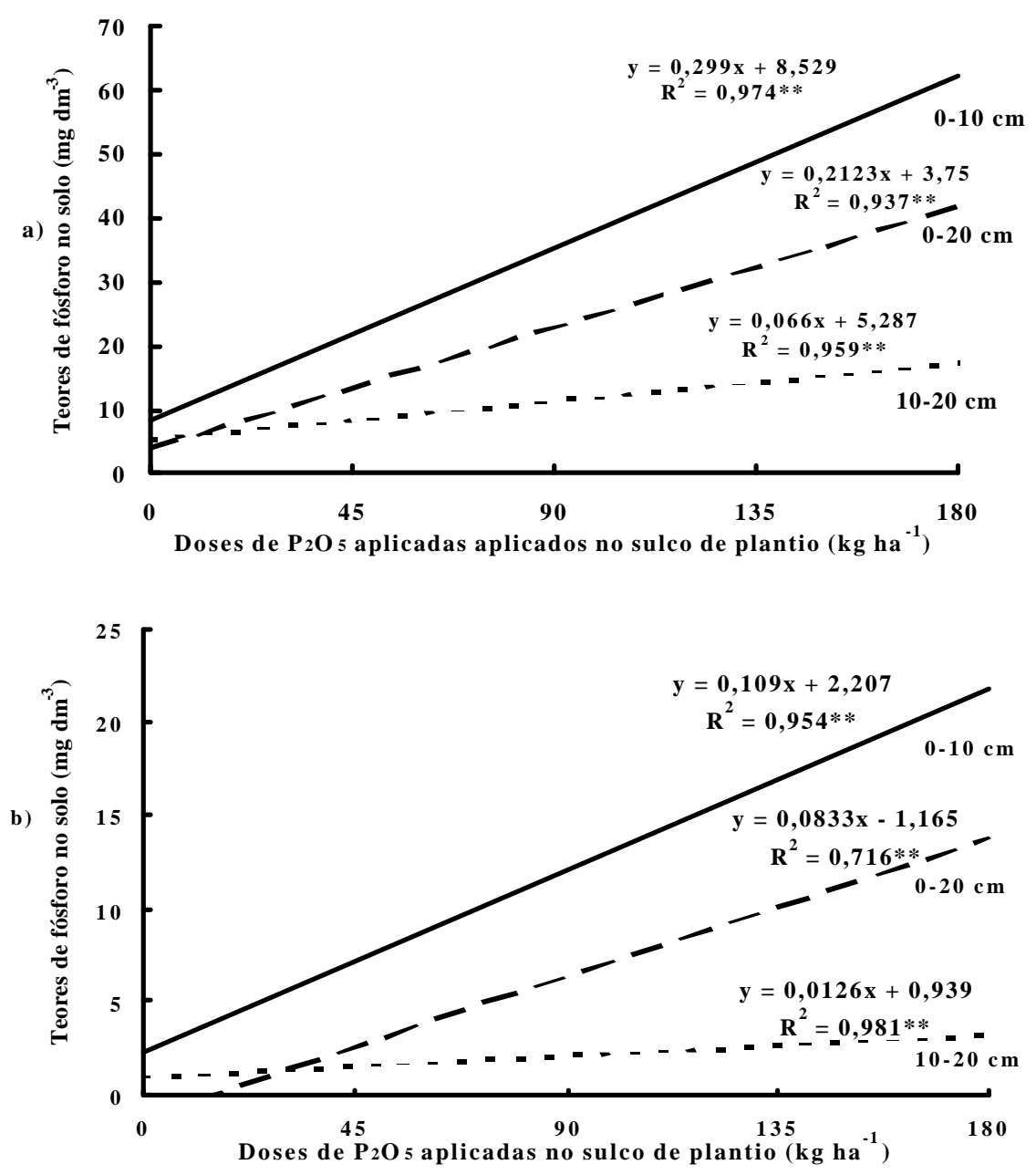

Figura 10 - Teores de fósforo no solo em função das doses de fósforo aplicadas no sulco de plantio em três profundidades de amostragem (segundo ano agrícola). a) Extraído pelo método da resina trocadora de íons; b) Extraído pelo método Mehlich-1. 
Para os dois métodos de extração de fósforo do solo, resina e Mehlich-1, os teores foram maiores nas profundidades de 0-10 e 0-20 cm, profundidades estas diretamente influenciadas pelas doses de fósforo utilizadas no sulco.

Os teores de fósforo no solo, obtidos pelos extrator resina aumentaram significativamente $(p>0,01)$ e de forma linear com as doses de frsforo aplicadas no sulco de plantio, em todas profundidades avaliadas, nas amostragens realizadas nas linhas de plantio, em trincheira e nas tipo mistura (Figura 11). As amostras coletadas nas entrelinhas, como já foi observado no primeiro ano agrícola, não foram influenciadas pelas doses de fósforo no sulco.

Nas profundidades de 0-10 e 0-20 cm (Figura 11a e c), as amostras coletadas nas linhas apresentaram teores cerca de 11 e $50 \%$ superiores aos teores obtidos nas amostragens do tipo mistura e em trincheira, respectivamente.

$\mathrm{Na}$ profundidade de $10-20 \mathrm{~cm}$, os teores obtidos para as amostragens em trincheira foram superiores aos teores obtidos para as amostragens na linha e do tipo mistura nas maiores doses de fósforo utilizadas no sulco de plantio.

Para o extrator Mehlich-1, as doses de fósforo aplicadas no sulco de plantio afetaram significativamente $(\mathrm{p}>0,01)$ as amostragens realizadas nas linhas e a do tipo mistura, nas profundidades de 0-10 e 0-20 cm (Figura 12a e c). Na profundidade de 10$20 \mathrm{~cm}$, além dos locais já citados, a amostragem realizadas em trincheira também foi afetada pelas doses de fósforo aplicadas no sulco de plantio (Figura 12b).

Tanto na profundidade de 0-10 como na de $0-20 \mathrm{~cm}$, as amostragens nas linhas de plantio apresentaram teores de fósforo no solo cerca de $48 \%$ superiores aos teores na amostragem tipo mistura. Na profundidade de $10-20 \mathrm{~cm}$, os teores de fósforo no solo, para as amostragens do tipo mistura e em trincheira, apresentaram-se praticamente iguais, sendo inferiores cerca de $13 \%$ em relação aos teores obtidos na amostragem nas linhas de plantio. Segundo Vasconcellos et al. (1982), o fósforo é extraído linearmente com a quantidade de solo proveniente do sulco de plantio, em área onde a adubação com fósforo foi realizada em sulco. 


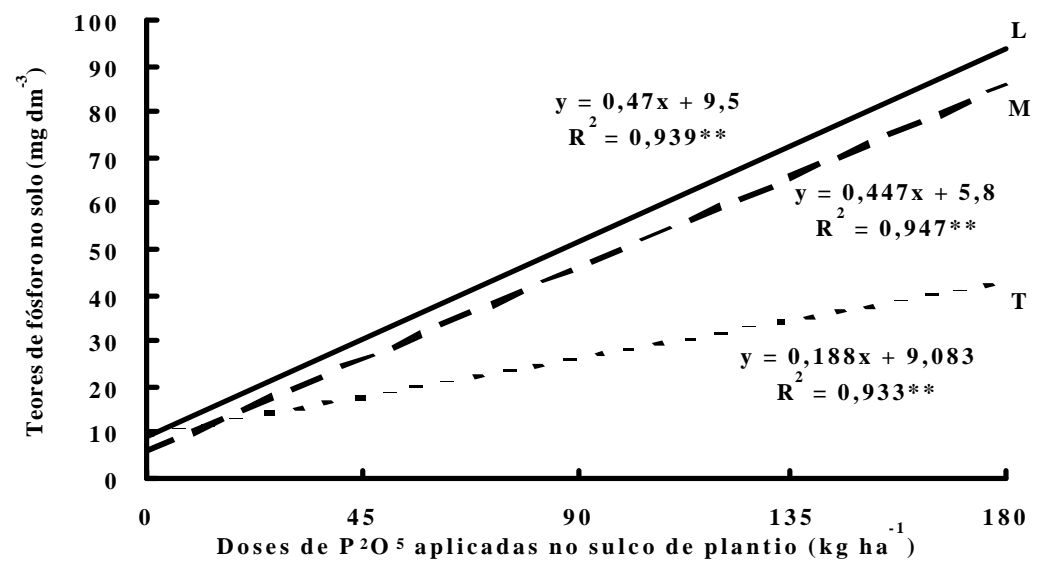

b)

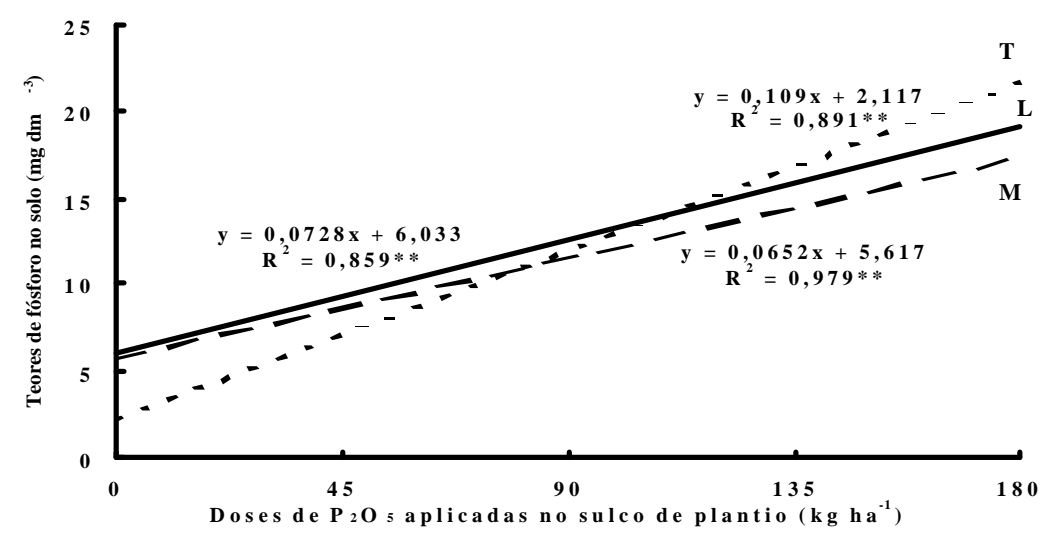

c)

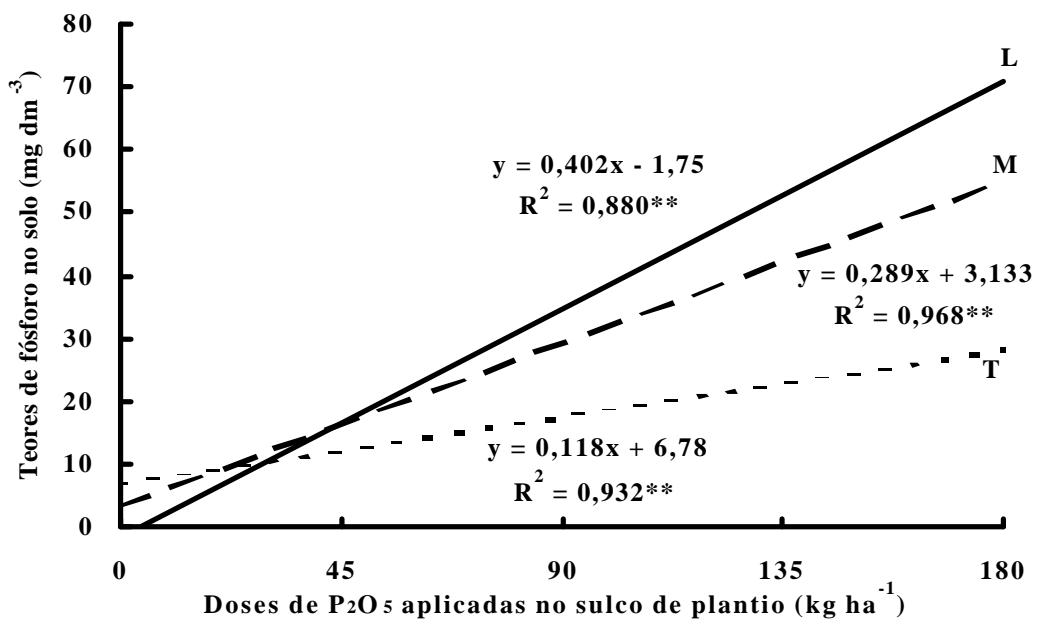

Figura 11 - Teores de fósforo no solo pelo extrator resina trocadora de íons em função das doses de fósforo aplicadas no sulco de plantio nas amostragens realizadas na linha de plantio (L), tipo mistura $(\mathrm{M})$ e em trincheira $(\mathrm{T})$, para o segundo ano agrícola. a) profundidade de $0-10 \mathrm{~cm}$; b) profundidade de 10 $20 \mathrm{~cm}$; c) profundidade de $0-20 \mathrm{~cm}$. 

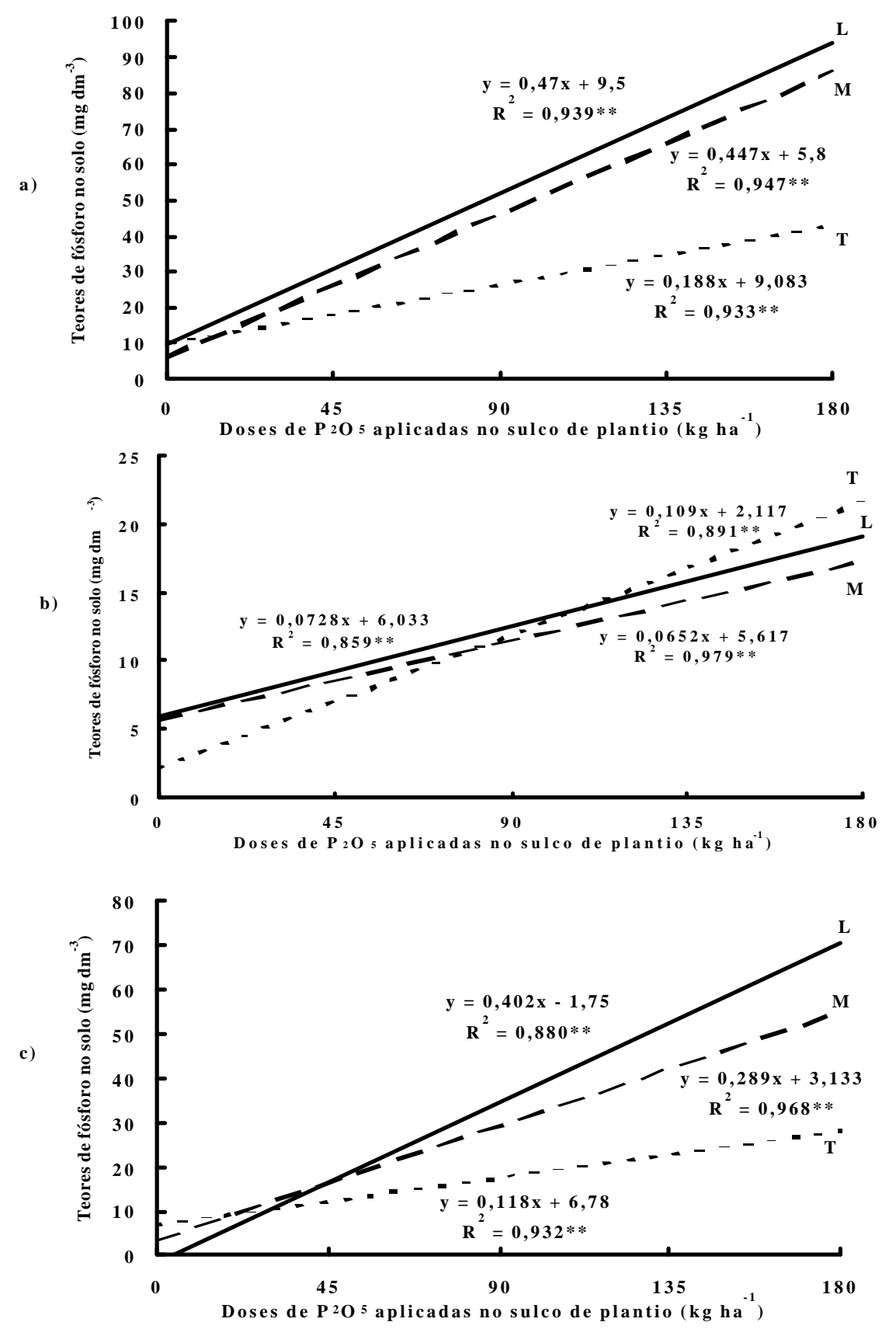

Figura 12 - Teores de fósforo no solo pelo extrator Mehlich-1 em função das doses de $\mathrm{P}_{2} \mathrm{O}_{5}$ aplicadas no sulco de plantio nas amostragens realizadas na linha de plantio (L), tipo mistura (M) e em trincheira (T), para o segundo ano agrícola. a) profundidade de $0-10 \mathrm{~cm}$; b) profundidade de $10-20 \mathrm{~cm}$; c) profundidade de $0-20 \mathrm{~cm}$. 


\subsubsection{Correlação entre o fósforo extraído do solo pelo método da resina trocadora de íons e o método Mehlich-1.}

Utilizando as amostras de todas as profundidades, a relação entre os extratores resina e Mehlich-1 apresentou coeficiente de correlação de 0,82 (Figura 13a), similar ao encontrado no primeiro ano agrícola. Quando ao ajustes foram estratificados pelas profundidades amostradas, o melhor ajuste foi obtido na camada de $0-20 \mathrm{~cm}(\mathrm{r}=0,87)$ e o menor ajuste na camada de $0-10 \mathrm{~cm}(\mathrm{r}=0,68)$, sendo que a camada de $10-20 \mathrm{~cm}$, apresentou coeficiente de correlação $(r=0,85)$, próximo ao encontrado para a camada de 0-20 cm. Estes valores de ajuste obtidos foram superiores aos encontrados no primeiro ano agrícola.

Na camada de 0-10 cm (Figura 13b), os extratores resina e Mehlich-1 não apresentaram boa correlação, o que deve ser reflexo das diferenças na capacidade extratora de cada método. De acordo com Bahia Filho et al. (1983), essas diferenças tem sido atribuídas à extração preferencial de determinada forma de fósforo, associada à maior atividade da forma preferencialmente extraída.

Quando se utilizou todos os dados amostrados, observou-se que os teores obtidos pelo extrator Mehlich-1 representaram 30\% dos teores obtidos pelo extrator resina. Para as camadas de 0-10, 10-20 e 0-20 cm, os teores obtidos pelo extrator Mehlich-1 representaram 34, 18 e $27 \%$ dos teores obtidos pelo extrator resina, respectivamente. Como observado no primeiro ano agrícola os maiores teores foram obtidos para o extrator resina. 

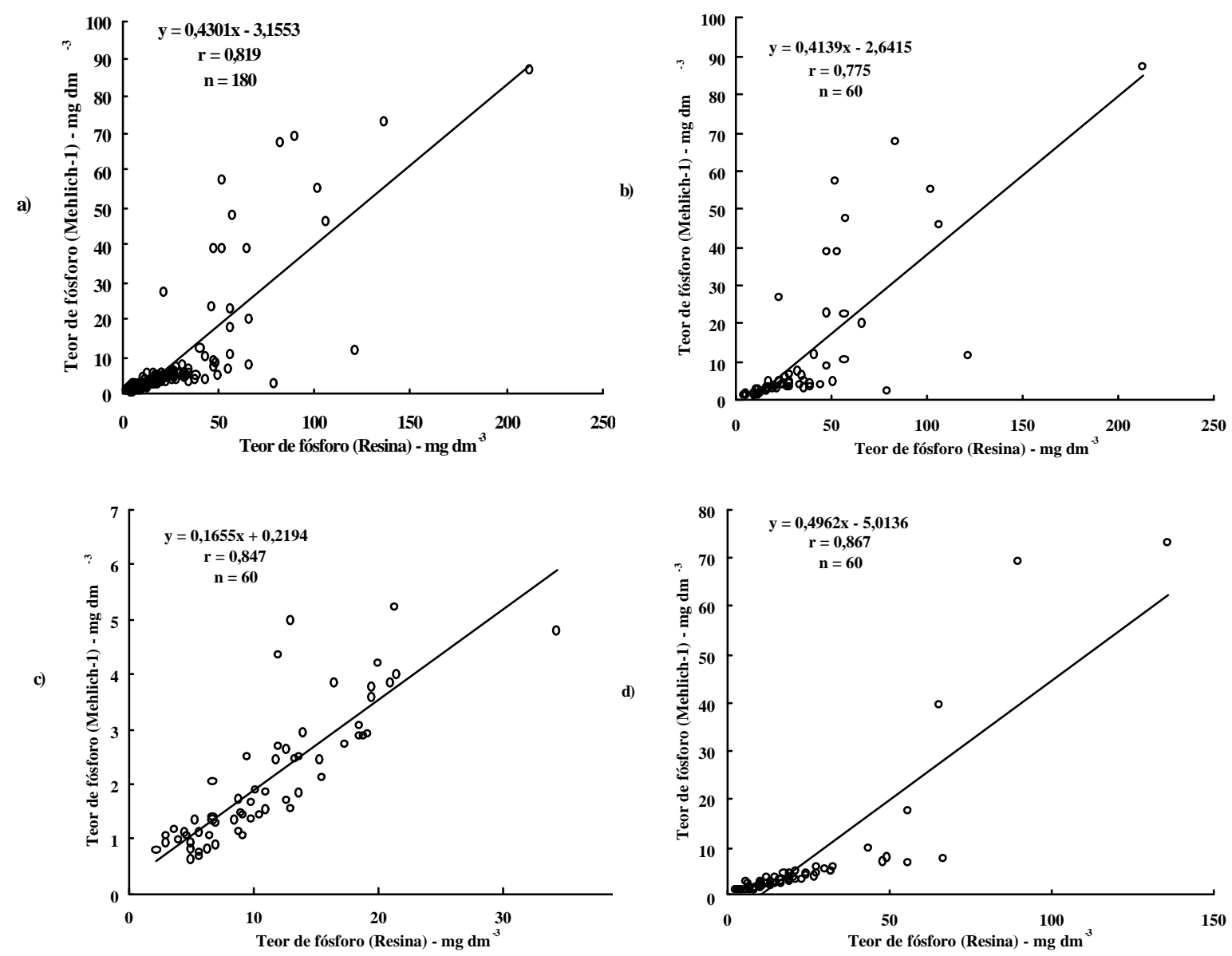

Figura 13 - Correlação entre os teores de fósforo extraídos pelo método resina e Mehlich-1, no segundo ano agrícola. a) teores gerais; b) teores na profundidade de 0-10 cm; c) teores na profundidade de $10-20 \mathrm{~cm}$; d) teores na profundidade de $0-20 \mathrm{~cm}$ 


\subsubsection{Efeito da fosfatagem e aplicação de fósforo em sulco na produção}

A produção da soja aumentou significativamente $(p>0,01)$ e forma linear com o aumento das doses de fósforo aplicadas tanto na fosfatagem como no sulco de plantio (Figura 14), o mesmo observado no primeiro ano agrícola. Para as doses de 100 e $200 \mathrm{~kg}$ $\mathrm{ha}^{-1}$ de fosfatagem, pode-se observar que o aumento em relação as doses de fósforo aplicado no sulco de plantio foram similares. No entanto, com já observado no primeiro anos agrícola, quando não se realizou fosfatagem, o aumento na produção foi mais pronunciado com a aplicação de fósforo no sulco. Quando se aplicou a maior dose de fósforo no sulco de plantio, obteve-se produções semelhantes as obtidas com e sem aplicação de fosfatagem, indicando baixa resposta da fosfatagem quando se utiliza doses elevadas de fósforo no sulco de plantio.

Observa-se que a produção de soja passou de 2260, na ausência de aplicação de fósforo, para $4698 \mathrm{~kg} \mathrm{ha}^{-1}$, quando se aplicou $200 \mathrm{~kg} \mathrm{ha}^{-1}$ de $\mathrm{P}_{2} \mathrm{O}_{5}$ na fosfatagem e $180 \mathrm{~kg} \mathrm{ha}^{-1}$ no sulco de plantio, o que representa aumento de $108 \%$.

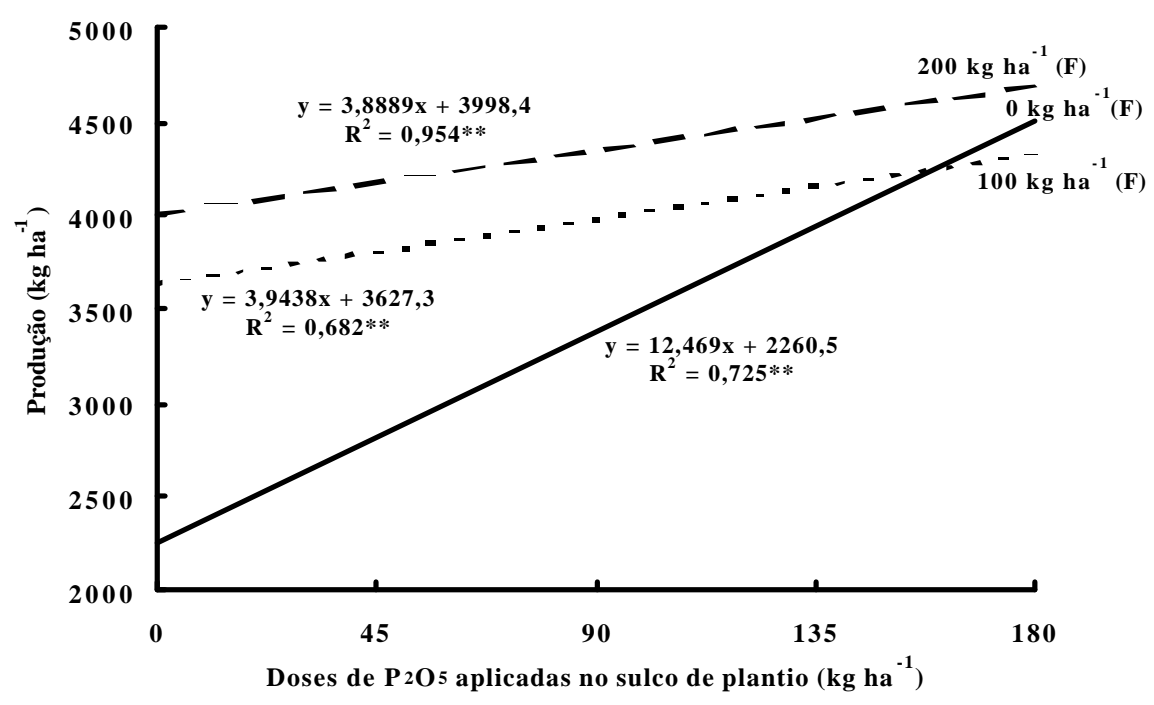

Figura 14 - Produção da soja, em kg ha ${ }^{-1}$, em função das doses de $\mathrm{P}_{2} \mathrm{O}_{5}$ aplicadas no sulco de plantio e das doses de $\mathrm{P}_{2} \mathrm{O}_{5}$ em fosfatagem (F), para o segundo ano agrícola. 
Ao correlacionar as produções obtidas com os teores de fósforo no solo, determinados pelos extratores resina e Mehlich-1, para os locais de amostragem e profundidades avaliadas (Tabela 9), foi possível observar que as melhores correlações, para os teores extraídos pelo método da resina, foram obtidas quando se coletou amostra na profundidade de 10-20 cm, para todos os locais de amostragem. Dentre estes, o que melhor se correlacionou com as produções obtidas, foi a amostragem realizada na linha de plantio na profundidade de $10-20 \mathrm{~cm}$. Silveira \& Stone (2002) relatam que, os teores de fósforo determinados na profundidade de 10-20 cm, em plantio direto, apresentaram melhores resultados quando comparados com os teores obtidos em plantio convencional.

Quanto aos teores de fósforo obtido pelo extrator Mehlich-1, as melhores correlações com as produções foram obtidas quando se coletou amostras nas entrelinhas, nas linhas e em trincheira, nas profundidades de 0-10, 10-20 e 0-20 cm, respectivamente. Dentre estas, as amostras coletadas na linha e em trincheira apresentaram comportamento similares.

Os maiores coeficientes de correlação obtidos, para a relação entre os teores de fósforo no solo e a produção, foram observados quando se utilizou o extrator resina, resultado semelhante aos observado no primeiro ano de cultivo. 
Tabela 9. Funções para variação na produção da soja, em função dos teores de fósforo no solo, determinada por dois extratores, para cada local de amostragem e profundidade avaliados, no segundo ano agrícola.

\begin{tabular}{|c|c|c|c|}
\hline Local & $\begin{array}{l}\text { Profundidade } \\
(\mathrm{cm})\end{array}$ & Função & $\mathrm{r}$ \\
\hline \multicolumn{4}{|c|}{ Resina } \\
\hline & $0-10$ & $Y=-2,7425 X^{2}+162,36 X+2224,6$ & 0,718 \\
\hline \multirow[t]{3}{*}{ Entrelinha } & $10-20$ & $Y=-17,703 X^{2}+485,77 X+1239,1$ & 0,771 \\
\hline & $0-20$ & $Y=-13,887 X^{2}+454,11 X+927,55$ & 0,821 \\
\hline & $0-10$ & $Y=-0,124 X^{2}+34,857 X+2730,1$ & 0,783 \\
\hline \multirow[t]{3}{*}{ Linha } & $10-20$ & $Y=-12,11 X^{2}+388,54 X+1380,1$ & 0,890 \\
\hline & $0-20$ & $Y=-0,2372 X^{2}+41,529 X+3037,6$ & 0,649 \\
\hline & $0-10$ & $Y=-0,3506 X^{2}+51,925 X+2682,9$ & 0,694 \\
\hline \multirow[t]{3}{*}{ Mistura } & $10-20$ & $Y=-14,675 X^{2}+456,65 X+972$ & 0,870 \\
\hline & $0-20$ & $Y=-1,3412 X^{2}+114,01 X+2267,7$ & 0,852 \\
\hline & $0-10$ & $Y=-1,638 X^{2}+127,86 X+2074,4$ & 0,810 \\
\hline \multirow[t]{4}{*}{ Trincheira } & $10-20$ & $Y=-3,4233 X^{2}+167,55 X+2616$ & 0,680 \\
\hline & $0-20$ & $Y=-1,957 X^{2}+142,56 X+2240,5$ & 0,798 \\
\hline & & Mehlich-1 & \\
\hline & $0-10$ & $Y=-247,56 X^{2}+1837,5 X+1069,6$ & 0,751 \\
\hline \multirow[t]{3}{*}{ Entrelinha } & $10-20$ & $Y=-162,92 X^{2}+1247,3 X+2454,7$ & 0,514 \\
\hline & $0-20$ & $Y=-421,84 X^{2}+2231,8 X+1411,8$ & 0,643 \\
\hline & $0-10$ & $Y=-0,2732 X^{2}+38,496 X+3237,5$ & 0,670 \\
\hline \multirow[t]{3}{*}{ Linha } & $10-20$ & $Y=-238,87 X^{2}+1596 X+1731,6$ & 0,777 \\
\hline & $0-20$ & $Y=-1,3923 X^{2}+112,96 X+3340,5$ & 0,544 \\
\hline & $0-10$ & $Y=-0,7756 X^{2}+58,601 X+3529,2$ & 0,390 \\
\hline \multirow[t]{3}{*}{ Mistura } & $10-20$ & $Y=-175,01 X^{2}+1236,2 X+2318,8$ & 0,572 \\
\hline & $0-20$ & $Y=-6,8977 X^{2}+300,19 X+2836,7$ & 0,691 \\
\hline & $0-10$ & $Y=-8,9996 X^{2}+277,2 X+2944,9$ & 0,639 \\
\hline \multirow[t]{2}{*}{ Trincheira } & $10-20$ & $Y=-112,15 X^{2}+847,5 X+2829,1$ & 0,593 \\
\hline & $0-20$ & $Y=-81,879 X^{2}+983,77 X+1734,4$ & 0,777 \\
\hline
\end{tabular}

\subsubsection{Efeito da fosfatagem e aplicação de fósforo em sulco sobre teor de fósforo na planta}

Os teores de fósforo nas folhas de soja aumentaram significativamente ( $>0,01)$ e de forma linear com o aumento das doses de fósforo aplicadas no sulco de 
plantio (Figura 8). Para as doses de fosfatagem utilizadas, houve efeito significativo nos teores foliares, contudo não ocorreu interação significativa com o fósforo aplicado no sulco para a dose de $200 \mathrm{~kg} \mathrm{ha}^{-1}$. Observa-se que os teores de fósforo foliar passaram de 2,37 , na ausência de aplicação de fósforo, para $3,34 \mathrm{~g} \mathrm{~kg}^{-1}$, quando se aplicou $100 \mathrm{~kg} \mathrm{ha}^{-1}$ de $\mathrm{P}_{2} \mathrm{O}_{5}$ na fosfatagem e $180 \mathrm{~kg} \mathrm{ha}^{-1}$ de $\mathrm{P}_{2} \mathrm{O}_{5}$ no sulco de plantio, o que representa aumento de $41 \%$. Os teores observados no segundo ano de plantio foram superiores ao observados no primeiro ano, alcançando a faixa considerada adequada para a cultura (Malavolta et al., 1989), nas doses mais elevadas de adubação fosfatada.

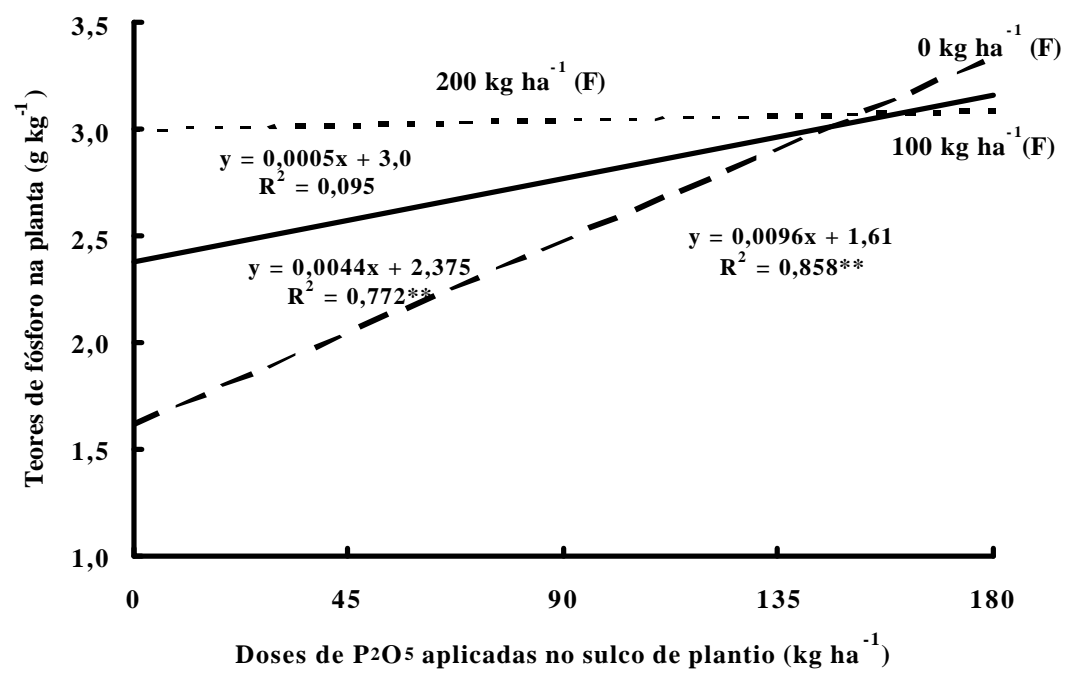

Figura 15 - Teores de fósforo na planta, em $\mathrm{g} \mathrm{kg}^{-1}$, em função das doses de $\mathrm{P}_{2} \mathrm{O}_{5}$ aplicadas no sulco de plantio e das doses de $\mathrm{P}_{2} \mathrm{O}_{5}$ em fosfatagem $(\mathrm{F})$, para $\mathrm{o}$ segundo ano agrícola.

Quando se correlacionou os teores de fósforo na planta com os teores de fósforo determinados no solo pelo extrator resina, nos diferentes locais de amostragem do solo e profundidade de coleta (Tabela 10), pode-se observar que as melhores correlações foram obtidas quando se realizou amostragem nas entrelinhas de plantio e na amostragem tipo mistura, nas profundidades de 010 e 10-20 cm, respectivamente. Para 
o extrator Mehlich-1, as melhores correlações foram obtida nas amostragens do tipo mistura e em trincheira, na profundidade de $0-20 \mathrm{~cm}$. Do mesmo modo que para o primeiro ano, o melhor ajuste entre os teores de fósforo no solo e os teores de fósforo na planta foi obtido no extrator resina.

Tabela 10. Funções para variação no teor de fósforo na folha, em função dos teores de fósforo no solo, determinada por dois extratores, para cada local de amostragem e profundidade avaliados, no segundo ano agrícola.

\begin{tabular}{|c|c|c|c|}
\hline Local & $\begin{array}{l}\text { Profundidade } \\
\text { (cm) }\end{array}$ & Função & $\mathrm{r}$ \\
\hline \multicolumn{4}{|c|}{ Resina } \\
\hline & $0-10$ & $Y=-0,0014 X^{2}+0,0853 X+1,8526$ & 0,708 \\
\hline \multirow[t]{3}{*}{ Entrelinha } & $10-20$ & $Y=-0,0113 X^{2}+0,2913 X+1,2412$ & 0,694 \\
\hline & $0-20$ & $Y=-0,0054 X^{2}+0,192 X+1,4508$ & 0,676 \\
\hline & $0-10$ & $Y=-0,00006 X^{2}+0,017 X+2,2014$ & 0,643 \\
\hline \multirow[t]{3}{*}{ Linha } & $10-20$ & $Y=-0,0047 X^{2}+0,1556 X+1,7356$ & 0,641 \\
\hline & $0-20$ & $Y=-0,0001 X^{2}+0,0223 X+2,305$ & 0,596 \\
\hline & $0-10$ & $Y=-0,0001 X^{2}+0,0185 X+2,2761$ & 0,530 \\
\hline \multirow[t]{3}{*}{ Mistura } & $10-20$ & $Y=-0,0072 X^{2}+0,2225 X+1,3542$ & 0,708 \\
\hline & $0-20$ & $Y=-0,0005 X^{2}+0,0461 X+2,0664$ & 0,645 \\
\hline & $0-10$ & $Y=-0,0005 X^{2}+0,0444 X+2,0596$ & 0,613 \\
\hline \multirow[t]{4}{*}{ Trincheira } & $10-20$ & $Y=-0,0021 X^{2}+0,0961 X+2,0523$ & 0,628 \\
\hline & $0-20$ & $Y=-0,0008 X^{2}+0,0607 X+2,055$ & 0,593 \\
\hline & & Mehlich & \\
\hline & $0-10$ & $Y=-0,0309 X^{2}+0,3907 X+1,9905$ & 0,554 \\
\hline \multirow[t]{3}{*}{ Entrelinha } & $10-20$ & $Y=-0,079 X^{2}+0,5984 X+2,0783$ & 0,416 \\
\hline & $0-20$ & $Y=-0,0179 X^{2}+0,3903 X+2,1069$ & 0,540 \\
\hline & $0-10$ & $Y=-0,0001 X^{2}+0,019 X+2,4585$ & 0,521 \\
\hline \multirow[t]{3}{*}{ Linha } & $10-20$ & $Y=-0,105 X^{2}+0,69 X+1,8472$ & 0,551 \\
\hline & $0-20$ & $Y=-0,0007 X^{2}+0,0605 X+2,4566$ & 0,533 \\
\hline & $0-10$ & $Y=-0,0005 X^{2}+0,0379 X+2,5408$ & 0,407 \\
\hline \multirow[t]{3}{*}{ Mistura } & $10-20$ & $Y=-0,082 X^{2}+0,5693 X+2,0491$ & 0,439 \\
\hline & $0-20$ & $Y=-0,0035 X^{2}+0,1495 X+2,2479$ & 0,583 \\
\hline & $0-10$ & $Y=-0,005 X^{2}+0,1499 X+2,2585$ & 0,571 \\
\hline \multirow[t]{2}{*}{ Trincheira } & $10-20$ & $Y=-0,0819 X^{2}+0,5516 X+2,1292$ & 0,449 \\
\hline & $0-20$ & $Y=-0,0439 X^{2}+0,5003 X+1,7$ & 0,637 \\
\hline
\end{tabular}




\subsection{Avaliação da fertilidade do solo em sistema de plantio direto}

Neste item são apresentados e discutidos resultados de parâmetros de fertilidade do solo, valores de $\mathrm{pH}$, teor de matéria orgânica e potássio, soma de bases (SB), capacidade de troca catiônica (CTC) e saturação por bases (V\%), para os diferentes tipos de amostragem de solo e profundidades, em dois anos agrícolas (2000/2001 e 2001/2002).

\subsubsection{Primeiro ano de agrícola (2000/2001)}

\subsubsection{Efeito do local e profundidade de amostragem}

\subsubsection{1 pH do solo}

Os valores de $\mathrm{pH}$ do solo em $\mathrm{CaCh}_{2}$ (Tabela 11) apresentaram pouca variação entre as profundidades e entre os locais de amostragem, sendo estas em torno de $2 \%$

$\mathrm{O}$ coeficiente de variação do $\mathrm{pH}$ do solo, para cada profundidade amostrada, apresentou-se baixo (1,38 a 1,49\%), menor que os encontrados por Silveira \& Stone (2002), que avaliaram o pH no solo para diferentes sistemas de preparo do solo, incluindo plantio direto e obtiveram $6,5 \%$.

Como o $\mathrm{pH}$ do solo depende, fundamentalmente, do material de origem, grau de intemperização e do manejo do solo (Volkweiss, 1989), este baixo coeficiente de variação encontrado pode estar relacionado ao manejo inicial realizado no solo, onde houve incorporação do calcário, visando que os cultivos sucessivos fossem realizados em sistema de plantio direto.

Dentre os locais de amostragem, em todas profundidades avaliadas, a amostragem realizada nas linhas de plantio apresentou valores de $\mathrm{pH}$ significativamente ( $p>0,01)$ inferiores aos encontrados nas amostragens realizadas na entrelinha e na amostragem tipo mistura. Os baixos valores de $\mathrm{pH}$ observados nestes locais de amostragem podem estar relacionados ao efeito da localização do sistema radicular, pela 
influência da absorção de nutrientes pelas plantas, o que leva à um aumento da atividade do íon hidrogênio, resultando na redução do $\mathrm{pH}$.

As amostragens tipo mistura foram significativamente maiores que as realizadas nas entrelinhas, para as profundidades de 010 e $10-20 \mathrm{~cm}$, sendo que nesta primeira profundidade, as amostras das entrelinhas não diferiram significativamente das realizadas nas linhas.

Quanto ao comportamento do $\mathrm{pH}$ nas profundidades avaliadas, os resultados obtidos seguiram a tendência esperada, apresentando valores maiores na camada de 0-10 cm. Na camada de $0-20 \mathrm{~cm}$ os valores do $\mathrm{pH}$ obtidos representam valor médio das duas camadas avaliadas.

Tabela 11. Valores de $\mathrm{pH}$ no solo em $\mathrm{CaCh}_{2}$ para os locais de amostragem avaliados e seu coeficiente de variação do solo, em diferentes profundidades, para o primeiro ano agrícola.

\begin{tabular}{ccccc}
\hline \multirow{2}{*}{$\begin{array}{c}\text { Profundidade } \\
\text { de amostragem } \\
(\mathrm{cm})\end{array}$} & Linha (L) & Entrelinha (E) & Mistura (LxE) & $\begin{array}{c}\text { Coeficiente de } \\
\text { variação } \\
(\%)\end{array}$ \\
\cline { 2 - 4 } $0-10$ & $5,7 \mathrm{~B}$ & $5,7 \mathrm{AB}$ & $5,7 \mathrm{~A}$ & 1,42 \\
$10-20$ & $5,4 \mathrm{~B}$ & $5,5 \mathrm{~B}$ & $5,6 \mathrm{~A}$ & 1,49 \\
$0-20$ & $5,4 \mathrm{~B}$ & $5,6 \mathrm{~A}$ & $5,6 \mathrm{~A}$ & 1,38 \\
\hline
\end{tabular}

Obs.: Médias seguidas por letras iguais na linha não diferem entre si pelo teste de Tukey ao nível de significância de $1 \%$.

\subsection{Matéria orgânica do solo}

Os teores de matéria orgânica do solo (Tabela 12) apresentaram baixa variação entre os locais de amostragem, ficando em torno de $3 \%$ para todas profundidades. Segundo Raij et al. (1996) estes teores são considerados médios. O 
coeficiente de variação entre locais de amostragem, para cada profundidade, apresentaram-se baixos, variando de 3,57 a 5,8\%, concordando com os encontrados por Souza (1992).

Quando as amostras foram coletadas estratificadas $(0-10$ e $10-20 \mathrm{~cm})$, não houve diferença significativa $(\mathrm{p}>0,01)$ entre os locais de amostragem. $O$ mesmo não pode ser observado quando coletou as amostras na profundidade de $0-20 \mathrm{~cm}$, onde a amostra do tipo mistura apresentou valores significativamente $(\mathrm{p}>0,01)$ maiores do que as amostras coletadas na linha de plantio, porém não diferiu da amostragem coletada na entrelinha.

Nas profundidades avaliadas, pode-se observar que houve uma diminuição no teor de matéria orgânica à medida que se aprofundou a amostragem, concordando com trabalhos de Carter \& Renier (1983), que observaram maior concentração de matéria orgânica na camada superficial devido aos restos culturais.

Tabela 12. Teores de matéria orgânica no solo, em $\mathrm{g} \mathrm{dm}^{-3}$, para os locais de amostragem avaliados e seu coeficiente de variação do solo, em diferentes profundidades, para o primeiro ano agrícola..

\begin{tabular}{ccccc}
\hline \multirow{2}{*}{$\begin{array}{c}\text { Profundidade } \\
\text { de amostragem }\end{array}$} & \multicolumn{3}{c}{ Locais de amostragem } & \multirow{2}{*}{$\begin{array}{c}\text { Coeficiente de } \\
\text { variação }\end{array}$} \\
\cline { 2 - 4 }$(\mathrm{cm})$ & Linha (L) & Entrelinha (E) & Mistura (LxE) & $(\%)$ \\
$0-10$ & $41 \mathrm{~A}$ & $\mathrm{~g} \mathrm{dm}^{-3}$ & & 3,57 \\
$10-20$ & $38 \mathrm{~A}$ & $41 \mathrm{~A}$ & $41 \mathrm{~A}$ & 5,28 \\
$0-20$ & $37 \mathrm{~B}$ & $39 \mathrm{~A}$ & $39 \mathrm{~A}$ & 3,65 \\
\hline
\end{tabular}

Obs.: Médias seguidas por letras iguais na linha não diferem entre si pelo teste de Tukey ao nível de significância de $1 \%$. 


\subsubsection{Potássio no solo}

Os teores de potássio do solo (Tabela 13) variaram em torno de $30 \%$ nas profundidade de 0-10 e 10-20 cm, e em $20 \%$ na profundidade de 0-20 cm, entre os locais de amostragem.

O coeficiente de variação encontrado para este nutriente foi maior que o encontrado para o $\mathrm{pH}$ e matéria orgânica, resultado este que pode ser atribuído a adubação potássica realizada. No entanto, o coeficiente de variação foi menor que o encontrado para o fósforo, reafirmando a consequência da adubação, já que a adubação fosfatada foi realizada em doses crescentes.

Observou-se quando as amostras foram coletadas nas linhas e quando se procedeu amostragem do tipo mistura, os teores de potássio apresentaram valores significativamente maiores $(\mathrm{p}>0,01)$ do que na amostragem realizada nas entrelinhas.

Klepker \& Anghinoni (1995) mostraram em seus estudos que, a variabilidade do potássio não se relaciona somente às linha de adubação, mas também a localização da planta. Como o potássio é lavado da parte aérea para o solo através da água da chuva, especialmente no final do ciclo, este tende a concentrar-se na linha de semeadura,

próximo ao colo da planta e diminuiu com o afastamento do mesmo, o que explica o menor teor de potássio encontrado nas amostras coletadas nas entrelinhas, pois o mesmo caminha no solo, principalmente pelo mecanismo de difusão. 
Tabela 13. Teores de potássio no solo, em $\mathrm{mmol}_{\mathrm{c}} \mathrm{dm}^{-3}$, para os locais de amostragem avaliados e seu coeficiente de variação do solo, em diferentes profundidades, para o primeiro ano agrícola.

\begin{tabular}{|c|c|c|c|c|}
\hline \multirow{2}{*}{$\begin{array}{c}\text { Profundidade } \\
\text { de amostragem }\end{array}$} & \multicolumn{3}{|c|}{ Locais de amostragem } & \multirow{2}{*}{$\begin{array}{l}\text { Coeficiente de } \\
\text { variação }\end{array}$} \\
\hline & Linha (L) & Entrelinha $(\mathrm{E})$ & Mistura (LxE) & \\
\hline$(\mathrm{cm})$ & & $\mathrm{mmol}_{\mathrm{c}} \mathrm{dm}^{-3}$ & & $(\%)$ \\
\hline $0-10$ & $5 \mathrm{~A}$ & $3 \mathrm{~B}$ & $4 \mathrm{~A}$ & 12,26 \\
\hline $10-20$ & $5 \mathrm{~A}$ & $3 \mathrm{~B}$ & $4 \mathrm{~A}$ & 9,35 \\
\hline $0-20$ & $3 \mathrm{~A}$ & $3 \mathrm{~B}$ & $4 \mathrm{~A}$ & 11,48 \\
\hline
\end{tabular}

Obs.: Médias seguidas por letras iguais na linha não diferem entre si pelo teste de Tukey ao nível de significância de $1 \%$.

\subsubsection{Soma de bases do solo (SB)}

A soma de bases do solo (SB) apresentou variações de 3, 11 e $10 \%$ para as profundidades de $0-10,10-20$ e $0-20 \mathrm{~cm}$, respectivamente, entre os locais de amostragem (Tabela 14).

A amostragem tipo mistura diferenciou-se significativamente $(p>0,01)$ da amostragem nas linhas de plantio, nas profundidade de $10-20$ e 0-20 cm, porém não diferenciou-se das amostragens nas entrelinhas. 
Tabela 14. Valores de soma de bases, em mmol $_{\mathrm{c}} \mathrm{dm}^{-3}$, para os locais de amostragem avaliados e seu coeficiente de variação do solo, em diferentes profundidades, para o primeiro ano agrícola.

\begin{tabular}{|c|c|c|c|c|}
\hline \multirow{2}{*}{$\begin{array}{l}\text { Profundidade } \\
\text { de amostragem }\end{array}$} & \multicolumn{3}{|c|}{ Locais de amostragem } & \multirow{2}{*}{$\begin{array}{l}\text { Coeficiente de } \\
\text { variação }\end{array}$} \\
\hline & Linha (L) & Entrelinha $(\mathrm{E})$ & Mistura (LxE) & \\
\hline$(\mathrm{cm})$ & & $\mathrm{mmol}_{\mathrm{c}} \mathrm{dm}^{-3}$ & & $(\%)$ \\
\hline $0-10$ & $90 \mathrm{~A}$ & $89 \mathrm{~A}$ & $92 \mathrm{~A}$ & 5,95 \\
\hline $10-20$ & $70 \mathrm{~B}$ & $73 \mathrm{AB}$ & $79 \mathrm{~A}$ & 9,96 \\
\hline $0-20$ & $76 \mathrm{~B}$ & $80 \mathrm{AB}$ & $85 \mathrm{~A}$ & 6,95 \\
\hline
\end{tabular}

Obs.: Médias seguidas por letras iguais na linha não diferem entre si pelo teste de Tukey ao nível de significância de $1 \%$.

\subsubsection{Capacidade de troca catiônica do solo (CTC)}

Os valores de CTC encontrados para os diferentes locais amostrados apresentaram pequena variação, em torno de $5 \%$ para todas profundidades avaliadas (Tabela 15).

Entre os locais amostrados, não houve diferença significativa $(\mathrm{p}>0,01)$ para os valores determinados. Quanto as profundidades avaliadas, pode-se observar pequena diminuição nos valores de CTC, quando compara-se as profundidades de 0-10 e 10-20 $\mathrm{cm}$. Para a profundidade de $0-20 \mathrm{~cm}$, como era de ser esperar, os valores determinados representam, praticamente, média dos valores determinados nas profundidades de $010 \mathrm{e}$ $10-20 \mathrm{~cm}$. 
Tabela 15. Valores de capacidade de troca catiônica do solo (CTC), em mmolc $\mathrm{dm}^{-3}$, para os locais de amostragem avaliados e seu coeficiente de variação do solo, em diferentes profundidades, para o primeiro ano agrícola.

\begin{tabular}{|c|c|c|c|c|}
\hline \multirow{2}{*}{$\begin{array}{l}\text { Profundidade } \\
\text { de amostragem }\end{array}$} & \multicolumn{3}{|c|}{ Locais de amostragem } & \multirow{2}{*}{$\begin{array}{l}\text { Coeficiente de } \\
\text { variação }\end{array}$} \\
\hline & Linha (L) & Entrelinha $(\mathrm{E})$ & Mistura (LxE) & \\
\hline (cm) & & $\mathrm{mmol}_{\mathrm{c}} \mathrm{dm}^{-3}$ & & (\%) \\
\hline $0-10$ & $117 \mathrm{~A}$ & $114 \mathrm{~A}$ & $118 \mathrm{~A}$ & 3,90 \\
\hline $10-20$ & $101 \mathrm{~A}$ & $103 \mathrm{~A}$ & $107 \mathrm{~A}$ & 6,45 \\
\hline $0-20$ & $107 \mathrm{~A}$ & $108 \mathrm{~A}$ & $113 \mathrm{~A}$ & 4,21 \\
\hline
\end{tabular}

Obs.: Médias seguidas por letras iguais na linha não diferem entre si pelo teste de Tukey ao nível de significância de $1 \%$.

\subsubsection{Saturação por bases do solo (V\%)}

Houve pouca variação nos valores de saturação por bases determinados para os locais de amostragem de solo (Tabela 16), sendo estes de 1, 7 e 6\% para as profundidades de 0-10, 10-20 e 0-20 cm, respectivamente.

Para a amostragem tipo mistura, pode-se observar, nas profundidades de 1020 e $0-20 \mathrm{~cm}$, diferenças significativas $(\mathrm{p}>0,01)$ nos valores de $\mathrm{V} \%$ em relação as amostragens realizadas nas linhas, mas ambas não diferiram das amostragens nas entrelinhas. Na profundidade de $0-10 \mathrm{~cm}$ não houve diferenças significativas nos valores de $\mathrm{V} \%$ para os diferentes locais de amostragens avaliados.

Em profundidade, ocorreu diminuição dos valores de V\%, da profundidade de 0-10 para a de 10-20 cm. Pode-se observar também que, os valores encontrados na profundidade de $0-20 \mathrm{~cm}$, foram praticamente uma média entre os valores encontrados nas profundidades de 0-10 e 10-20 cm, o que era esperado. 
Tabela 16. Valores de saturação por bases (\%) para os locais de amostragem avaliados e seu coeficiente de variação do solo, em diferentes profundidades, para o primeiro ano agrícola..

\begin{tabular}{ccccc}
\hline \multirow{2}{*}{$\begin{array}{c}\text { Profundidade } \\
\text { de amostragem }\end{array}$} & \multicolumn{3}{c}{ Locais de amostragem } & \multirow{2}{*}{$\begin{array}{c}\text { Coeficiente de } \\
\text { variação }\end{array}$} \\
\cline { 2 - 3 }$(\mathrm{cm})$ & Linha (L) & Entrelinha (E) & Mistura (LxE) & $(\%)$ \\
$0-10$ & $77 \mathrm{~A}$ & $78 \mathrm{~A}$ & $78 \mathrm{~A}$ & 2,35 \\
$10-20$ & $68 \mathrm{~B}$ & $70 \mathrm{AB}$ & $73 \mathrm{~A}$ & 4,04 \\
$0-20$ & $70 \mathrm{~B}$ & $73 \mathrm{AB}$ & $75 \mathrm{~A}$ & 3,44 \\
\hline
\end{tabular}

Obs.: Médias seguidas por letras iguais na linha não diferem entre si pelo teste de Tukey ao nível de significância de $1 \%$.

\subsubsection{Segundo ano de agrícola (2001/2002)}

\subsubsection{Efeito do local e profundidade de amostragem}

\subsubsection{1 pH do solo}

Os valores de $\mathrm{pH}$ do solo em $\mathrm{CaCh}_{2}$ (Tabela 17) praticamente não variaram entre os locais de amostragem, nas profundidades avaliadas.

O coeficiente de variação do $\mathrm{pH}$ do solo, para cada profundidade amostrada, apresentou-se baixo (1,36 a 1,72\%), menor que os encontrados por Silveira \& Stone (2002), que ao avaliarem o pH no solo para diferentes sistemas de preparo do solo, incluindo plantio direto, obtiveram 6,5\% e, semelhantes aos obtidos no primeiro anos de cultivo.

Dentre os locais de amostragem, em todas profundidades avaliadas, não houve diferença significativa $(\mathrm{p}>0,01)$ para os valores de $\mathrm{pH}$ no solo, que também praticamente não variaram em profundidade. 
Tabela 17. Valores de $\mathrm{pH}$ no solo em $\mathrm{CaCh}$ para os locais de amostragem avaliados e seu coeficiente de variação do solo, em diferentes profundidades, para o segundo anos agrícola.

\begin{tabular}{|c|c|c|c|c|c|}
\hline \multirow{2}{*}{$\begin{array}{l}\text { Profundidade } \\
\text { de } \\
\text { amostragem }\end{array}$} & \multicolumn{4}{|c|}{ Locais de amostragem } & \multirow{2}{*}{$\begin{array}{l}\text { Coeficiente } \\
\text { de variação }\end{array}$} \\
\hline & Linha (L) & Entrelinha (E) & Mistura (LxE) & Trincheira(T) & \\
\hline$(\mathrm{cm})$ & & & & & $(\%)$ \\
\hline $0-10$ & $5,5 \mathrm{~A}$ & $5,5 \mathrm{~A}$ & $5,5 \mathrm{~A}$ & $5,5 \mathrm{~A}$ & 1,56 \\
\hline $10-20$ & $5,3 \mathrm{~A}$ & $5,2 \mathrm{~A}$ & $5,2 \mathrm{~A}$ & $5,2 \mathrm{~A}$ & 1,72 \\
\hline $0-20$ & $5,2 \mathrm{~A}$ & $5,2 \mathrm{~A}$ & $5,3 \mathrm{~A}$ & $5,3 \mathrm{~A}$ & 1,36 \\
\hline
\end{tabular}

\subsection{Matéria orgânica do solo}

Os teores de matéria orgânica do solo (Tabela 18) apresentaram baixa variação entre os locais de amostragem avaliados, apresentando uma variação de 5, 12 e $6 \%$ para as profundidades de $010,10-20$ e $0-20 \mathrm{~cm}$, respectivamente. O coeficiente de variação entre locais de amostragem, para cada profundidade, apresentaram-se baixos, variando de 2,33 a 3,36\%, menores que os obtidos para o primeiro ano agrícola.

As amostragens realizadas em trincheira, na profundidade de $0-10 \mathrm{~cm}$, apresentaram teores significativamente maiores $(p>0,01)$ que os obtidos nas amostragens nas entrelinha, no entanto não diferiu das amostragens realizadas nas linhas de plantio e das tipo mistura. Os maiores teores de matéria orgânica na amostragem coletadas em trincheira podem ser atribuídos a extensão da camada superficial coletada, camada esta onde se encontra maiores teores a matéria orgânica devido aos restou das culturas anteriores, no plantio direto.

O mesmo não foi observado na profundidade de $10-20 \mathrm{~cm}$, onde a amostragem realizada na entrelinha diferiu significativamente das amostragens realizadas em trincheira $\mathrm{e}$ das tipo mistura, não diferindo significativamente da 
amostragem nas linhas. A amostragem tipo mistura também diferiu significativamente da amostragem em trincheira. Para a profundidade de $0-20 \mathrm{~cm}$, houve diferença significativa somente entre a amostragem tipo mistura e amostragem nas linhas.

Nas profundidades avaliadas, pode-se observar que houve diminuição no teor de matéria orgânica à medida que se aprofundou a amostragem, como foi observado no primeiro ano agrícola.

Tabela 18. Teores de matéria orgânica, em $\mathrm{g} \mathrm{dm}^{-3}$, no solo para os locais de amostragem avaliados e seu coeficiente de variação do solo, em diferentes profundidades para o segundo anos agrícola.

\begin{tabular}{|c|c|c|c|c|c|}
\hline \multirow{2}{*}{$\begin{array}{c}\text { Profundidade } \\
\text { de } \\
\text { amostragem }\end{array}$} & \multicolumn{4}{|c|}{ Locais de amostragem } & \multirow{2}{*}{$\begin{array}{l}\text { Coeficiente } \\
\text { de variação }\end{array}$} \\
\hline & Linha (L) & Entrelinha $(\mathrm{E})$ & Mistura (LxE) & Trincheira(T) & \\
\hline$(\mathrm{cm})$ & \multicolumn{4}{|c|}{$\mathrm{g} \mathrm{dm}^{-3}$} & $(\%)$ \\
\hline $0-10$ & $35 \mathrm{AB}$ & $34 \mathrm{~B}$ & $35 \mathrm{AB}$ & $36 \mathrm{~A}$ & 2,33 \\
\hline $10-20$ & $32 \mathrm{AB}$ & $33 \mathrm{~A}$ & $32 \mathrm{~B}$ & $29 \mathrm{C}$ & 3,36 \\
\hline $0-20$ & $31 \mathrm{~B}$ & $32 \mathrm{AB}$ & $33 \mathrm{~A}$ & $32 \mathrm{AB}$ & 3,08 \\
\hline
\end{tabular}

Obs.: Médias seguidas por letras iguais na linha não diferem entre si pelo teste de Tukey ao nível de significância de $1 \%$.

\subsubsection{Potássio no solo}

Para os teores de potássio do solo (Tabela 19) houve maior variação entre os locais de amostragens, sendo de 34\%, 62\% e 20\% para as profundidades de 0-10, 10-20 e 0-20 cm, respectivamente. O coeficiente de variação encontrado para o potássio obteve a mesma tendência observada no primeiro ano agrícola.

Observou-se que quando as amostras foram coletadas nas linhas, os teores deste nutriente apresentaram valores significativamente maiores $(p>0,01)$ do que na amostragem realizada na entrelinhas e em trincheira, nas profundidade de 010 e 10-20 
$\mathrm{cm}$, enquanto que na profundidade de $0-20 \mathrm{~cm}$, diferiu significativamente da amostragem tipo mistura e das entrelinhas. $\mathrm{Na}$ amostragem nas entrelinhas, nas profundidades de 0-10 e 0-20 cm, os teores de potássio foram significativamente menores que os demais locais de amostragem, semelhante ao observado no primeiro ano agrícola. Para a profundidade de $10-20 \mathrm{~cm}$, os menores teores foram observados na amostragem em trincheira.

Tabela 19. Teores de potássio no solo, em $\mathrm{mmol}_{\mathrm{c}} \mathrm{dm}^{-3}$, para os locais de amostragem avaliados e seu coeficiente de variação do solo, em diferentes profundidades para o segundo ano agrícola.

\begin{tabular}{|c|c|c|c|c|c|}
\hline \multirow{2}{*}{$\begin{array}{c}\text { Profundidade } \\
\text { de } \\
\text { amostragem }\end{array}$} & \multicolumn{4}{|c|}{ Locais de amostragem } & \multirow{2}{*}{$\begin{array}{l}\text { Coeficiente } \\
\text { de variação }\end{array}$} \\
\hline & Linha (L) & Entrelinha $(\mathrm{E})$ & Mistura (LxE) & Trincheira(T) & \\
\hline$(\mathrm{cm})$ & \multicolumn{4}{|c|}{$\mathrm{mmol}_{\mathrm{c}} \mathrm{dm}^{-3}$} & $(\%)$ \\
\hline $0-10$ & $3,5 \mathrm{~A}$ & $2,3 \mathrm{C}$ & $3,2 \mathrm{AB}$ & $3,0 \mathrm{~B}$ & 10,66 \\
\hline $10-20$ & $3,2 \mathrm{~A}$ & $2,6 \mathrm{~B}$ & $2,9 \mathrm{~B}$ & $1,2 \mathrm{C}$ & 11,06 \\
\hline $0-20$ & $2,3 \mathrm{~A}$ & $1,8 \mathrm{C}$ & $2,2 \mathrm{BC}$ & $1,9 \mathrm{AB}$ & 10,59 \\
\hline
\end{tabular}

Obs.: Médias seguidas por letras iguais na linha não diferem entre si pelo teste de Tukey ao nível de significância de $1 \%$.

\subsubsection{Soma de bases do solo (SB)}

A soma de bases do solo (SB) apresentou pouca variações em seus valores para os locais de amostragem, sendo esta de 5\% para as profundidades de 0-10 e 0-20 $\mathrm{cm}$, e de 16\% para a profundidade de 10-20 (Tabela 20).

Com um baixo coeficiente de variação, não apresentou diferença significativa ( $>0,01)$ entre os locais de amostragem nas profundidade de 0-10 e 0-20 cm. Na profundidade de 10-20 cm, a amostragens em trincheira apresentou valores significativamente menores que os demais locais de amostragem avaliados. 
Tabela 20. Valores de soma de bases, em $\mathrm{mmol}_{\mathrm{c}} \mathrm{dm}^{-3}$, para os locais de amostragem avaliados e seu coeficiente de variação do solo, em diferentes profundidades para o segundo ano agrícola.

\begin{tabular}{|c|c|c|c|c|c|}
\hline \multirow{2}{*}{$\begin{array}{c}\text { Profundidade } \\
\text { de } \\
\text { amostragem }\end{array}$} & \multicolumn{4}{|c|}{ Locais de amostragem } & \multirow[t]{2}{*}{$\begin{array}{l}\text { Coeficiente } \\
\text { de variação }\end{array}$} \\
\hline & Linha (L) & Entrelinha $(\mathrm{E})$ & Mistura (LxE) & Trincheira(T) & \\
\hline$(\mathrm{cm})$ & \multicolumn{4}{|c|}{$\mathrm{mmol}_{\mathrm{c}} \mathrm{dm}^{-3}$} & $(\%)$ \\
\hline $0-10$ & $90 \mathrm{~A}$ & $88 \mathrm{~A}$ & $91 \mathrm{~A}$ & $93 \mathrm{~A}$ & 6,620 \\
\hline $10-20$ & $71 \mathrm{~A}$ & $74 \mathrm{~A}$ & $72 \mathrm{~A}$ & $62 \mathrm{~B}$ & 8,625 \\
\hline $0-20$ & $71 \mathrm{~A}$ & $75 \mathrm{~A}$ & $75 \mathrm{~A}$ & $75 \mathrm{~A}$ & 6,939 \\
\hline
\end{tabular}

Obs.: Médias seguidas por letras iguais na linha não diferem entre si pelo teste de Tukey ao nível de significância de $1 \%$.

\subsubsection{Capacidade de troca catiônica do solo (CTC)}

Os valores de CTC encontrados para os diferentes locais amostrados apresentaram uma pequena variação (Tabela 21), sendo esta de $4 \%$ para as profundidades de $0-10$ e $0-20 \mathrm{~cm}$, e de $10 \%$ para a profundidade de $10-20 \mathrm{~cm}$, com um coeficiente de variação baixo, semelhante aos obtidos no primeiro ano agrícola

Entre os locais amostrados, não houve diferença significativa $(\mathrm{p}>0,01)$ para os valores determinados nas profundidade de 010 e $0-20 \mathrm{~cm}$. Na profundidade de 10-20 $\mathrm{cm}$, a amostragem em trincheira apresentou valores significativamente menores aos encontrados para as amostragens nas entrelinhas nas tipo mistura. Quanto as profundidades avaliadas, pode-se observar uma diminuição nos valores de CTC, quando compara-se as profundidades de $0-10$ e $10-20 \mathrm{~cm}$. 
Tabela 21. Valores de capacidade de troca catiônica do solo (CTC), em $\mathrm{mmol}_{\mathrm{c}} \mathrm{dm}^{-3}$, para os locais de amostragem avaliados e seu coeficiente de variação do solo, em diferentes profundidades para o segundo ano agrícola.

\begin{tabular}{cccccc}
\hline \multirow{2}{*}{$\begin{array}{c}\text { Profundidade } \\
\text { de } \\
\text { amostragem }\end{array}$} & \multicolumn{4}{c}{ Locais de amostragem } & $\begin{array}{c}\text { Coeficiente } \\
\text { de variação }\end{array}$ \\
\cline { 2 - 4 }$(\mathrm{cm})$ & Linha (L) & Entrelinha (E) & Mistura (LxE) & Trincheira(T) & \\
\hline $0-10$ & $90 \mathrm{~A}$ & $88 \mathrm{~A}$ & $91 \mathrm{~A}$ & $93 \mathrm{~A}$ & 6,62 \\
$10-20$ & $71 \mathrm{~A}$ & $74 \mathrm{~A}$ & $72 \mathrm{~A}$ & $62 \mathrm{~B}$ & 8,62 \\
$0-20$ & $71 \mathrm{~A}$ & $75 \mathrm{~A}$ & $75 \mathrm{~A}$ & $75 \mathrm{~A}$ & 6,94
\end{tabular}

Obs.: Médias seguidas por letras iguais na linha não diferem entre si pelo teste de Tukey ao nível de significância de $1 \%$.

\subsubsection{Saturação por bases do solo (V\%)}

Houve pouca variação nos valores de saturação por bases determinados para os locais de amostragem de solo (Tabela 22), com variações de 10 e 6\% para as profundidades de $10-20$ e $0-20 \mathrm{~cm}$, respectivamente, cujos valores foram semelhantes aos obtidos no primeiro ano de cultivo.

Nas profundidades de 010 e $0-20 \mathrm{~cm}$ não houve diferenças significativas nos valores de V\% para os diferentes locais de amostragens avaliados. Na profundidade de 10-20 cm, a amostragem em trincheira apresentou valores significativamente menores $(\mathrm{p}>0,01)$ que os obtidos para os demais locais de amostragem. Observou-se uma diminuição dos valores de V\%, da profundidade de 0-10 cm para a de $10-20 \mathrm{~cm}$. 
Tabela 22. Valores de saturação por bases, em \%, para os locais de amostragem avaliados e seu coeficiente de variação do solo, em diferentes profundidades para o segundo ano agrícola.

\begin{tabular}{|c|c|c|c|c|c|}
\hline \multirow{2}{*}{$\begin{array}{c}\text { Profundidade } \\
\text { de } \\
\text { amostragem }\end{array}$} & \multicolumn{4}{|c|}{ Locais de amostragem } & \multirow[t]{2}{*}{$\begin{array}{l}\text { Coeficiente } \\
\text { de variação }\end{array}$} \\
\hline & Linha $(\mathrm{L})$ & Entrelinha (E) & Mistura (LxE) & Trincheira(T) & \\
\hline$(\mathrm{cm})$ & & & $\%$ & & $(\%)$ \\
\hline $0-10$ & $73 \mathrm{~A}$ & $73 \mathrm{~A}$ & $73 \mathrm{~A}$ & $73 \mathrm{~A}$ & 2,87 \\
\hline $10-20$ & $66 \mathrm{~A}$ & $66 \mathrm{~A}$ & $65 \mathrm{~A}$ & $60 \mathrm{~B}$ & 4,45 \\
\hline $0-20$ & $63 \mathrm{~A}$ & $66 \mathrm{~A}$ & $66 \mathrm{~A}$ & $67 \mathrm{~A}$ & 4,49 \\
\hline
\end{tabular}

Obs.: Médias seguidas por letras iguais na linha não diferem entre si pelo teste de Tukey ao nível de significância de $1 \%$. 


\section{CONCLUSÕES}

Î As análises de amostras do solo coletadas nas linhas e amostragem do tipo mistura (linhas e entrelinha na proporção 1:1) apresentaram maiores teores de fósforo no solo nos dois extratores utilizados (resina e Mehlich-1);

Î A aplicação de fósforo em área total (fosfatagem) e em sulco de plantio aumentou, de forma linear, os teores de fósforo no solo, principalmente nas profundidades de 0-10 e $0-20 \mathrm{~cm}$;

Î As amostragens de solo realizadas nas linhas de plantio e a do tipo mistura revelaram serem mais sensíveis na quantificação dos teores de fósforo no solo em função da aplicação do nutriente, seja em área total ou no sulco de plantio;

Î $\mathrm{O}$ extrator resina trocadora de íons foi mais eficiente na extração do fósforo no solo do que o extrator Mehlich-1;

Î Os teores de fósforo no solo, extraídos pela resina trocadora de íons, em amostras coletadas nas linhas de plantio e as tipo mistura, nas profundidades $0-10$ e $0-20 \mathrm{~cm}$, apresentaram melhor correlação (positiva e significativa) com os teores de fósforo na planta, obtidos pela técnica da diagnose foliar, e com a produção de grãos de soja, em relação ao método de extração Mehlich-1; 
î Os demais parâmetros referentes à fertilidade do solo, que foram avaliados, apresentaram baixa variação entre os locais de amostragem, com exceção do potássio, o qual apresentou maiores nas amostras coletadas nas linhas de plantio;

Î Ocorreu um gradiente de concentração dos índices de fertilidade à partir da superfície do solo. Quando se amostrou na profundidade de $020 \mathrm{~cm}$, os teores obtidos foram praticamente uma média entre os teores obtidos nas profundidades de 010 e 10 $20 \mathrm{~cm}$ 


\section{REFERÊNCIAS BIBLIOGRÁFICAS}

ALBUQUERQUE, J.A.; REINERT, D.J.; FIORIN, J.E. Variabilidade do solo e planta em podzólico vermelho-amarelo. Revista Brasileira Ciência do Solo, v. 20, p.151157, 1996.

ALVAREZ V.; V.H., FONSECA, D.M. Definição de doses de fósforo para determinação da capacidade máxima de adsorção de fosfato e para ensaios em casa de vegetação. Revista Brasileira de Ciência do Solo, v.14, p. 49-55, 1990.

ANGHINONI, I. Amostragem do solo no sistema plantio direto. In: SIMPÓSIO SOBRE FERTILIDADE DO SOLO E NUTRIÇÃO DE PLANTAS NO SISTEMA PLANTIO DIRETO, 1., Ponta Grossa, 2000. Anais. Ponta Grossa: Associação dos Engenheiros Agrônomos dos Campos Gerais, 2000. p.17-25.

ANGHINONI, I.; SALET, R.L. Variabilidade espacial de propriedades químicas do solo no sistema plantio direto. In: CURSO SOBRE MANEJO DO SOLO NO SISTEMA PLANTIO DIRETO, Castro, 1995. Anais. Castro: Fundação ABC, 1995. p.279-290.

ANGHINONI, I.; VOLKWEISS, S.J. Recomendações de uso de fertilizantes no Brasil. In: ESPINOSA, W.; OLIVEIRA, A.J. In: SIMPÓSIO NA AGRICULTURA BRASILEIRA, Brasília, 1984. Anais. Brasília: Empresa Brasileira de Pesquisa Agropecuária, 1984. p.179-204. 
ANGHINONI, I.; SALET, R.L. Amostragem do solo e as recomendações de adubação e calagem no sistema plantio direto. In: NUERNBERG, N.J.(Ed.). Conceitos e fundamentos do sistema plantio direto, Lages : Núcleo Regional Sul/SBCS, 1998. p.27-52.

BAHIA FILHO, A.F.C.; BRAGA, J.M.; RIBEIRO, A.C.; NOVAIS, R.F. Sensibilidade de extratores químicos à capacidade tampão de fósforo. Revista Brasileira de Ciência do Solo, v.7, p.243-249, 1983.

BALL-COELHO, B.; SALCEDO,I.H.; TIESSEN, H.; STEWART, J.W.B. Short and long-term phosphorus dynamics in a fertilized Ultissol under sugarcane. Soil Science Society of America Journal, v.57, p.1027-34, 1993.

BAYER, C.; MIELNICZUK, J. Características químicas do solo afetadas por métodos de preparo e sistemas de cultura. Revista Brasileira Ciência do Solo, v.21, p.105$112,1997$.

BRASIL, E.C.; MURAOKA, T. Extratores de fósforo em solos da Amazônia tratados com fertilizantes fosfatados. Revista Brasileira de Ciência do Solo, v. 21, p.599606, 1997.

BRASIL. Ministério da Agricultura e do Abastecimento. Empresa Brasileira de Pesquisa Agropecuária. Sistema Brasileiro de Classificação de Solos. Brasília: EMBRAPACNPS, 1999. 412p.

CAIRES, E.F.; BANZATTO, D.A.; FONSECA, A.F. Calagem na superfície em sistema plantio direto. Revista Brasileira de Ciência do Solo, v.24, p.161-169, 2000. 
CANTARELlA, H.; ABREU, C.A.; BERTON, R.S. Fornecimento de nutrientes pela matéria orgânica do solo. In: GUERRINI, I.A. e BULL,L.T. (Ed.), Encontro sobre matéria orgânica do solo Jaboticabal: UNESP, p.63-122, 1992.

CARTER, M.R.; RENNIE, D.A. Nitrogen transformations under zero and shallowtillage. Soil Science Society of America Journal, v.48, p.1077-1081, 1983.

CHANG, S.C.; JACKSON, M.L. Soil phosphorus fractions in some representative soils. Journal of Soil Science, v.9, p.109-119, 1958.

COGO, N.P. Soil erosion and productivity in Brazil. In: RD ANNUAL MEETING PROGRAM, 83., Denver: America Fertility Society, 1991. p. 71

COMISSÃO DE FERTILIDADE DO SOLO - CFSRS/SC. Recomendações de adubação e calagem para os Estados do Rio Grande do Sul e Santa Catarina. 3.ed. Passo Fundo: Sociedade Brasileira de Ciência do Solo - Núcleo Regional Sul/ Empresa Brasileira de Pesquisa Agropecuária/Centro Nacional de Pesquisa de Trigo, 1995. 224p.

COUTO, E.G. Variabilidade espacial de propriedades do solo influenciando a agricultura em escala regional e local no sul do estado do Mato Grosso. Porto Alegre, 1997. 183p. Tese (Doutorado) - Universidade Federal do Rio Grande do Sul

DERPSCH, R. Expansão mundial do plantio direto. Revista Plantio Direto, n.59, p.3240, 2000.

DORAN, J.W. Soil microbial and biochemical changes associated with reduced tillage. Soil Science Society of America Journal, v.44, p.765-71, 1980. 
ECKER, D.J.; DICK, W.A.; JONHNSON, J.W. Response of no-tillage corn grown and soybean and corn residues to several nitrogen fertilizer. Agronomy Journal, v. 78, p. $231-235,1985$

ELTZ, F.L.F.; PEIXOTO, R.T.G.; JASTER, F. Efeitos de sistemas de preparo do solo nas propriedades físicas e químicas de um Latossolo Bruno álico. Revista Brasileira de Ciência do Solo, v. 13, n.2, p.259-67, 1989.

SILVA, F.C. de (Org.) Manual de análises químicas de solos, plantas e fertilizantes Brasília: Embrapa comunicação para transferência de tecnologia, 1999, 370p.

FASSBENDER, H.W.; MULLER, L.; BALERDI, F. Estudio en suelos de America Central II. Formas y su relación con las plantas. Revista Interamericana Ciências Agrárias, v.18, n.4, p.333-347, 1968.

FREIRE, F.M.; NOVAIS, R.F.; BRAGA, J.M., et al. Adubação fosfatada para a cultura da soja (Glycine max (L) Merril) baseada no fósforo disponível e no fator "capacidade ". Revista Brasileira de Ciência do Solo, v. 3, p.105-111, 1979.

GASSEN, D.N.; GASSEN, F.R. Plantio direto: o caminho do futuro. Passo Fundo: Aldeia Sul, 1996. 207p.

GRANDE, M.A.; CURI, N.; QUAGGIO, J.A. Disponibilidade de fósforo pelos extratores Mehlich e resina, em solos cultivados com arroz irrigado. Revista Brasileira de Ciência do Solo, v.10, n. 1, p. 45-50, 1986.

HAVLIN, J.L.; SCHLEGER, A.J. Increasing soil organic matter with soil/crop management. Better Crops, v.74, n.1,p. 7-9, 1990. 
HELAL, H.M.; SAUERBEK, D.R. Influence of plant roots on $\mathrm{C}$ and $\mathrm{P}$ metabolism in soil. Plant and Soil, v.76, p.175-182, 1984.

HOLTZ, G.P. Dinâmica da decomposição da palhada e da distribuição do carbono, nitrogênio e fósforo numa rotação de culturas sob plantio direto na região de Carambeí (PR). Curitiba, 1995. 129p. Dissertação (Mestrado) - Universidade Federal do Paraná.

JAMES, D.W.; WELLS, K.L. Soil sample collection and handling: technique based on source and degree of field variability. 3. ed. In: WESTWERMAN, R.L. (Ed). Soil Testing and Plant Analisys. Madison: Soil Science Society of America, 1990. p. $25-44$.

JAMES, D.W.; HURST, R.L. Soil Sampling Tchnique for Band-Fertilized, No-Till Fields with Monte Carlo Simulations. Soil Science Society American Journal. n. 59, p.1768-1772, 1995.

JONES, J.N.; MOODY, J.E.; SHEAR, G.M. et al The no-tillage system for corn Zea mays L.) Agronomy Journal, v. 60, p. 17-20, 1968.

KAMPRATT, E.J. Exchangeable aluminium as a criterion for leming leached mineral soils. Soil Science Society America Proceeding, v. 34, n. 2, p. 252-54, 1977.

KITCHEN, N.R.; HAVLIN, J.L.; WESTFALL, D.G. Soil sampling under no-till banded phosphorus. Soil Science Society America Journal, v.54, p.1661-1665, 1990.

KLEPKER, D.; ANGHINONI, I. Phosphate uptake and corn root distribution as affected by fertilizer placement and soil tillage. Agronomy - trends in Agricultural Science, v.1, p.111-115, 1993. 
KLEPKER, D.; ANGHINONI, I. Características físicas e químicas do solo afetados por métodos de preparo e modos de adubação. Revista Brasileira Ciência do Solo, v.19, p.395-401, 1995.

KRAY, C.H.; SALET, R.L.; ANGHINONI, I. Variabilidade horizontal e amostragem dirigida do solo no sistema plantio direto. Porto Alegre: Departamento de Solos da Faculdade de Agronomia da UFRGS, 1998. 6p. (Relatório de Pesquisa).

LIBARDI, P.L.; PREVEDELLO, C.L.; PAULETTO, E.A. et al. Variabilidade espacial da umidade, textura e densidade de partícula ao longo de uma transeção. Revista Brasileira Ciência do Solo, v.10, p.85-90, 1986.

MALAVOLTA, E.; VITTI, G.C.; OLIVEIRA, S.A. Avaliação do estado nutricional de plantas: princípios e aplicações. 2. ed. Piracicaba: POTAFOS, 1997. cap. 5, p. $135-198$ e cap. 6, p. 231-299.

MELSTED, S.W.; PECK, T.R. The principles of soil testing. In: WALSH, L.M. \& BEATON, J.D. (Eds). Soil testing and plant analysis. Madison: Soil Science Society of America, 1973. p.13-21.

MIYAZAWA, M.; CHIERICE, G. O.; PAVAN, M. A. Amenização da toxicidade de alumínio às raízes do trigo pela complexação com ácidos orgânicos. Revista Brasileira de Ciência do Solo, v.16, p.209-215, 1992.

MOSCHLER, W.W.; MARTENS, D.C.; SHEAR, G.M. Residual fertility in soils continuously field cropped to corn by conventional tillage and no-tillage methods. Agronomy Journal, v.67, p.45-48, 1975. 
MUZILLI, C. Influência do sistema de plantio direto, comparado com o convencional, sobre a fertilidade da camada arável do solo. Revista Brasileira Ciência do Solo, v.7, p.95-102, 1983.

NOVAIS, R.F.; BARROS, N.F.; NEVES, J.C.L. Interpretação de analise química do solo para o crescimento e desenvolvimento de Eucalyptus ssp. Niveis críticos de implantação e de manutenção. Revista Arvore, v. 10, p.105-111, 1986.

NOVAIS, R.F.; KAMPRATH, E.J. Fósforo recuperado em três extratores químicos como função do fósforo aplicado no solo e do "fator capacidade". Revista Brasileira de Ciência do Solo, v.3, p.41-46, 1979.

NOVELINO, J.O.; NOVAIS, R.F.; NEVES, J.C.L.; et al. Solubilização de fosfato de Araxá, em diferentes tempos de incubação com amostras de cinco Latossolos, na presença e na ausência de calagem. Revista Brasileira de Ciência do Solo, v. 9, p.13-22, 1985.

PARRA, M.S. Dinâmica da matéria orgânica e de nutrientes num Latossolo Roxo distrófico submetido aos sistemas de plantio convencional e direto e a diferentes sucessões de culturas. Viçosa, 1986. 98p. Dissertação (Mestrado)- Universidade Federal de Viçosa.

PAVAN, M.A. Ciclagem de nutrientes e mobilidade de íons no solo sob plantio direto. Revista Plantio Direto, n.41, p.8-12, 1997.

PETRERE, C., SALET, R.L., ANGHINONI, I. Produtividades de culturas nos sistemas plantio direto e convencional no sul do Brasil. In: REUNIÃO BRASILEIRA DE CIÊNCIA DO SOLO, Lages, SC, 1996. Resumos expandidos Lages. NRS/SBCS, 1996. p.74-76. 
PHILLIPS, S.H. Introduction to no-tillage. In: PHILLIPS, R.E.; PHILLIPS, S.H. (Ed). No-tillage Agriculture: principles and practices. New York: Was Nostrand Reinhold Company Inc., 1984, p. 1-9.

POTTKER, D. Correção da acidez de solo no sistema plantio direto. In: SEMINÁRIO INTERNACIONAL DO SISTEMA DE PLANTIO DIRETO, 1., Passo Fundo, RS 1995. Resumos. Passo Fundo: EMBRAPA-CNPT, 1995. p.15-19.

RAIJ, B.van. Seleção de métodos de laboratório para avaliar a disponibilidade de fósforo em solos. . Revista Brasileira de Ciência do Solo, v. 2, n.1, p.1-9, 1978.

RAIJ, B. van. Avaliação da fertilidade do solo. Instituto da fertilidade do solo.. Potassa (Ed.). Piracicaba: Potassa \& Fosfato / Instituto Internacional 1981. p.95-100.

RAIJ, B. van. Fertilidade do solo e adubação. São Paulo: Agronômica Ceres, 1991. $343 \mathrm{p}$.

RAIJ, B. van; ANDRADE, J. C de; CANTARELlA, H; QUAGGIO, J. A. Análise Química para Avaliação da Fertilidade de Solos Tropicais. Campinas: Instituto Agronômico, 2001, 285p.

RAIJ, B. van; CANTARELlA, H; QUAGGIO, J. A FURLANI, A.M.C. Recomendação de adubação e calagem para o Estado de São Paulo. 2. ed. Campinas: Instituto Agronômico, 1996, 285p. (Boletim 100)

RAIJ, B. van; FEITOSA, C.T. Correlação entre o P extraído do solo por diversos extratores químicos e o absorvido pelo milho. Bragantia, v.39, n.1, p.51-57, 1980.

RAIJ, B. van; QUAGGIO, J.A. Métodos de análise de solo para fins de fertilidade. Campinas: Instituto Agronômico, 1983. 31p. (Boletim técnico, 81). 
RAIJ, B.van; QUAGGIO, J.A.; SILVA, N.M. da Extraction of phosphorus, potassium, calcium and magnesium from soils by na ion-exchange resin procedure. Communications in Soil Science and Plant Analyses, v.17, p.547-566, 1986.

SÁ, J.C. de M. Manejo da fertilidade do solo no plantio direto. Castro: Fundação ABC 1993. 96p.

SÁ, J.C. de M. Plantio direto: transformações e benefícios ao agrossistema. In: CURSO SOBRE MANEJO DO SOLO NO SISTEMA PLANTIO DIRETO, Castro, PR. 1995. Anais. Castro: Fundação ABC, 1995, p. 9-20.

SÁ, J.C. de M. Manejo da fertilidade do solo no sistema plantio direto. In: INTERRELAÇÃO FERTILIDADE, BIOLOGIA DO SOLO E NUTRIÇÃO DE PLANTAS. Lavras: UFLA/DCS, 1999. p.267-319.

SALET, R.L.; KRAY, C.H.; FORNARI, T.G. et al. Variabilidade horizontal e amostragem de solo no sistema plantio direto. In: REUNIÃO SULBRASILEIRA DE CIÊNCIA DO SOLO, 1., Lages, SC, 1996. Resumos. Lages, SC: NRS/SBCS 1996. p. 74-76.

SANTOS, H.L. dos; VASCONCELLOS, C.A. Determinação do número de amostras de solo para análise química em diferentes condições de manejo. Revista Brasileira Ciência do Solo, v.11, p.97-100, 1987.

SCHLINDWEIN, J.A. Variabilidade da fertilidade e amostragem de solo no sistema plantio direto. Porto Alegre, 1999. 110p. Dissertação (Mestrado) - Universidade Federal do Rio Grande do Sul. 
SCHLINDWEIN, J.A.; ANGHINONI, I. Variabilidade horizontal de atributos de fertilidade e amostragem do solo no sistema plantio direto. Revista Brasileira de Ciência do Solo, v.24, p.85-91, 2000a.

SCHLINDWEIN, J.A.; ANGHINONI, I. Variabilidade vertical de fósforo e potássio disponíveis e profundidades de amostragem do solo no sistema plantio direto. Ciência Rural, v. 30, n. 4, p. 611-17, 2000 b.

SCHLINDWEIN, J.A.; SALET, L.R.; ANGHINONI, I. Variabilidade dos índices de fertilidade do solo no sistema plantio direto e coleta de amostras representativas do solo. In: REUNIÃO BRASILEIRA DE FERTILIDADE DO SOLO E NUTRIÇÃO DE PLANTAS, 23; REUNIÃO BRASILEIRA SOBRE MICORRIZAS, 7.; SIMPÓSIO BRASILEIRO SOBRE MICROBIOLOGIA DO SOLO, 5.; REUNÃO BRASILEIRA DE BIOLOGIA DO SOLO, Caxambú, 1998. Resumos. Caxambú: Sociedade Brasileira de Ciência do Solo, 1998. p.265.

SCHULTE, E.E.; BUNDY, L.G. Sampling soils for testing under conservation tillage. Better Crops Plant Food, v.69, p.22-23, 1985.

SHEAR, G.M.; MOSCHLER, W.W. Continuous corn by the no-tillage and conventional tillage methods: a six-year comparision. Agronomy Journal, v.61, p.524-526, 1969.

SIDIRAS, N.; PAVAN, M.A. Influência do sistema de manejo de solo no seu nível de fertilidade. Revista Brasileira Ciência do Solo, v. 9, p.249-254, 1985.

SILVEIRA, P.M.; STONE, L.F. Profundidade de amostragem do solo sob plantio direto para avaliação de características químicas. Revista Brasileira Ciência do Solo, v.26, p.157-162, 2002. 
SOUZA, L.S. Variabilidade espacial do solo em sistemas de manejo. Porto Alegre, 1992. 162p Tese (Doutorado) - Universidade Federal do Rio Grande do Sul

SOUZA, L.S.; COGO, N.P.; VIEIRA, S.R. Variabilidade de fósforo, potássio e matéria orgânica no solo em relação a sistemas de manejo. Revista Brasileira de Ciência do Solo, v.22, p.77-86, 1998.

THOMAS, G.M.; WELLS, K.L.; MURDOCK, L. Fertilization and liming. In: PHILIPS, R.E., THOMAS, G.W., BLEVINS, L. (Ed.). No-tillage research: Research Reports and Reviews. Lexington: Univ. Kentucky, College of agriculture and Agric. Exp. Sta., 1981. p.43-54.

THUROW, J.M., SCHLINDWEIN, J.A.; GIANELlO, C.; PIVOTTO, A.C. Fósforo disponível determinados por resina enterrada no solo (Compact disc). In: REUNIÃO BRASILEIRA DE FERTILIDADE DO SOLO E NUTRIÇÃO DE PLANTAS, 25., Rio de janeiro, 2002 Resumos , Rio de Janeiro: UFRRJ, 2002.

TISDALE , S.L.; NELSON, W.L.; BEATON, J.D.; HAVLIN, J.L.. Soil Fertility and Fertilizers. 5. ed. New York: Mc Millan, 1993.

TRIPLETT JUNIOR, G.B.; VAN DOREN. Nitrogen, phosphorus and potassium fertilization on no-tillage maize. Agronomy Journal, v.61, p.637-639, 1969.

TYLER, D.D. Soil sampling in no-tillage cropping. Better Crops Plant Food, v.69, p.26-27, 1985.

UNGER, P.W. Organic matter, nutrient and $\mathrm{pH}$ distribution in no- and conventional tillage semiarid soils. Agronomy Journal, v.83, p.186-189, 1991. 
VALE, F.; OLIVEIRA, C.F.; ALVES, M.E. et al. Efeito residual de fertilizantes fosfatados numa sucessão centrosema-braquiaria e determinação do fósforo disponível com diferentes extratores. Revista de agricultura, v.73, p.345-357. 1998.

VASCONCELLOS, C.A.; SANTOS, H.L. do; BAHIA FILHO, A.F.C.; OLIVEIRA, A.C. Amostragem de solo em área com adubação fosfatada aplicada a lanço e no sulco de plantio. Revista Brasileira Ciência do Solo, v.6, p. 221-225, 1982.

VASCONCELLOS, C.A.; BRAGA, J.M.; NOVAIS, R.F.; PINTO, O.C.B. Fósforo em dois latossolos do Estado de MG. III- Relações entre planta, solo e Fósforo. Revista Ceres, v.22, n.119, p.22-49, 1975.

VOLKWEISS, S.J. Química da acidez do solo In: SEMINARIO SOBRE CORRETIVOS DA ACIDEZ DO SOLO, 2, Santa Maria, 1989. Anais... Santa Maria: Universidade Federal de Santa Maria, 1989. p.7-38.

WEIL,R.R.; BENEDETTO, P.W.; SIKORA, L.J.; BANDEL, V.A. Influence of Tillage Practices on Phosphorus Distribution and Forms in Three Ultisols. Agronomy Journal, v.80, p. 503-509, 1988.

WESTFALL, D.G.; KITCHEN, M.R.; HAVLIN, J.L. Soil sampling guidelines for band applied phosphorus. Better Crops Plant Food, v.75, p.24-28, 1991.

WILDING, L.P.; DREES, L.R. Spatial variability and pedology. In: WILDING, L.P.; SMECK, N.E.; HALL, G.F. (Ed). Pedogenesis and soil taxonomy. I. Concepts and interactions. Amsterdam: Elsevier Science, 1983. p.83-116. 
WUNCHE, W.A. ; DENARDIN, J.E. Perdas de solo por escorrimento de água sob chuva natural em latossolo vermelho escuro nas culturas de trigo e soja. In: ENCONTRO NACIONAL DE PESQUISAS SOBRE CONSERVAÇÃO DO SOLO, 2., Passo Fundo, 1978. Anais, Passo Fundo: EMBRAPA/CNPTrigo, 1978, p. 289-296. 